University of Chicago Law School

Chicago Unbound

Journal Articles

Faculty Scholarship

1989

\title{
The Origins and Historical Understanding of Free Exercise of Religion
}

Michael W. McConnell

Follow this and additional works at: https://chicagounbound.uchicago.edu/journal_articles

Part of the Law Commons

\section{Recommended Citation}

Michael W. McConnell, "The Origins and Historical Understanding of Free Exercise of Religion," 103 Harvard Law Review 1409 (1989).

This Article is brought to you for free and open access by the Faculty Scholarship at Chicago Unbound. It has been accepted for inclusion in Journal Articles by an authorized administrator of Chicago Unbound. For more information, please contact unbound@law.uchicago.edu. 


\title{
HARVARD LAW REVIEW
}

\section{THE ORIGINS AND HISTORICAL UNDERSTANDING OF FREE EXERCISE OF RELIGION}

\author{
Michael W. McConnell
}

\section{TABLE OF CONTENTS}

PAGE

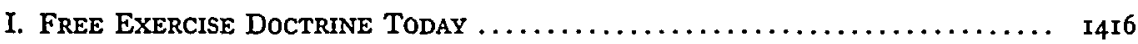

II. Free Exercise Before the Constitution $\ldots \ldots \ldots \ldots \ldots \ldots \ldots \ldots \ldots \ldots \ldots$ I42 I

A. Four Approaches to Church-State Relations in the Colonies ............ I42I

B. Locke and Theories of Religious Toleration .................... 1430

C. Development of the Expansive Conception of Religious Freedom ......... 1436

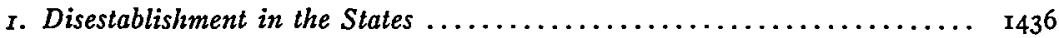

2. The Evangelical Impetus Toward Religious Freedom ............. I437

3. Advances Beyond Locke in the Popular Understanding

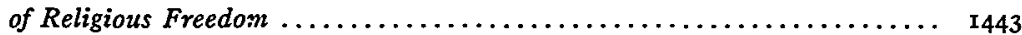

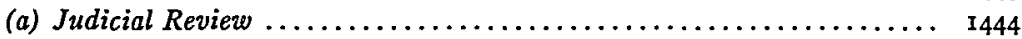

(b) The Nature and Role of Religion ................... I445

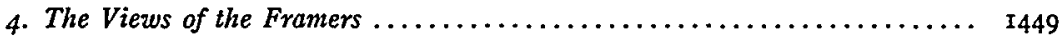

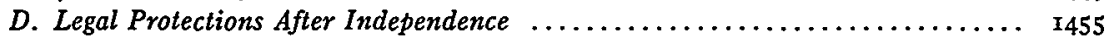

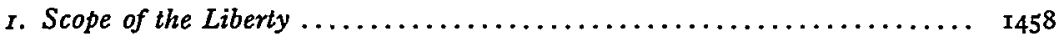

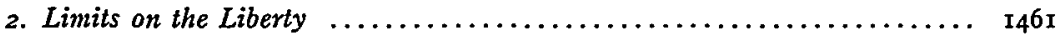

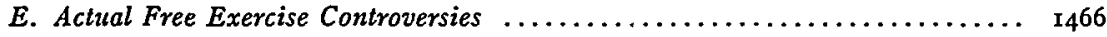

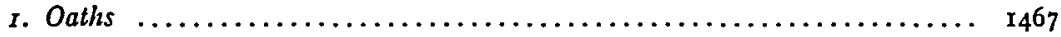

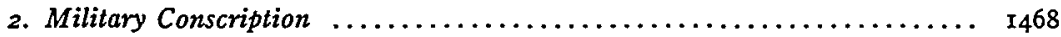

3. Religious Assessments $\ldots \ldots \ldots \ldots \ldots \ldots \ldots \ldots \ldots \ldots \ldots \ldots \ldots \ldots \ldots \ldots \ldots$

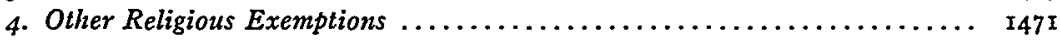

III. The Federal free Exercise Clause $\ldots \ldots \ldots \ldots \ldots \ldots \ldots \ldots \ldots \ldots \ldots \ldots \ldots$ I473

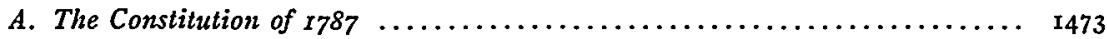

B. Framing and Ratifying the Free Exercise Clause ............... I480

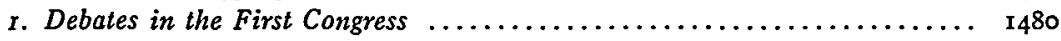

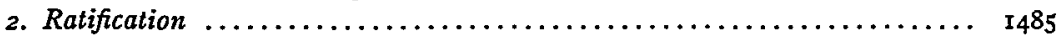

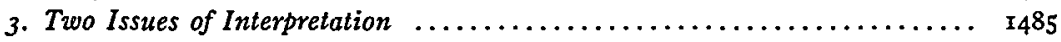

(a) The Meaning of "Prohibiting" $\ldots \ldots \ldots \ldots \ldots \ldots \ldots \ldots \ldots \ldots \ldots \ldots \ldots$

(b) The Substitution of "Free Exercise of Religion" for the

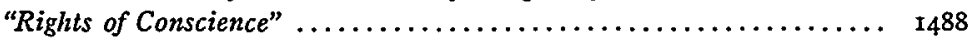

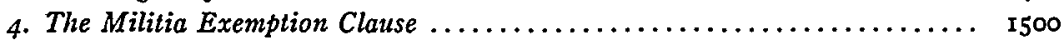

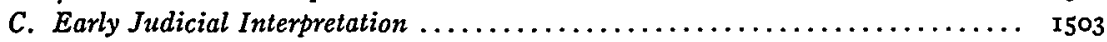

D. Summary of the Evidence $\ldots \ldots \ldots \ldots \ldots \ldots \ldots \ldots \ldots \ldots \ldots \ldots \ldots \ldots \ldots \ldots \ldots$ III

IV. Conclusion: The New American Philosophy of RELIGIOUS PLURALISM $\ldots \ldots \ldots \ldots \ldots \ldots \ldots \ldots \ldots \ldots \ldots \ldots \ldots \ldots \ldots \ldots \ldots$ 


\title{
ARTICLE
}

\section{THE ORIGINS AND HISTORICAL UNDERSTANDING OF FREE EXERCISE OF RELIGION}

\author{
Michael W. Mc Connell ${ }^{*}$
}

\begin{abstract}
The question whether the free exercise clause requires the granting of religious exemptions from generally applicable laws with secular purposes has generated lively debate. Beyond a few narrow circumstances, the Supreme Court and legal commentators have rejected claims to free exercise exemptions. In this Article, Professor McConnell argues that this debate has largely proceeded in an ahistorical fashion and has ignored the unique American conception of religious freedom from which the free exercise clause emerged. Professor McConnell discusses the approaches to church-state relations in the American colonies and traces the development of free exercise provisions in both the colonies and the post-independence states. Contrary to modern perceptions, he argues, the impetus for free exercise provisions came from the evangelical religious movements of the period, movements that espoused the primacy of religious conscience over secular laws and that viewed the constitutional guarantee of free exercise as protecting the right actively to fulfill religious duties without state interference. He contends, moreover, that the framers adopted the terminology "free exercise of religion" in place of the alternative, "rights of conscience," to ensure protection for religiously motivated conduct and to make clear that protection would not extend to secular claims of conscience. After discussing early nineteenth-century judicial interpretations, Professor McConnell concludes that an interpretation of the free exercise clause that mandates religious exemptions was both within the contemplation of the framers and consonant with popular notions of religious liberty and limited government that existed at the time of the framing.
\end{abstract}

$I^{\mathrm{N}}$ the winter of I8I2-I8I3, Daniel Philips entered the confessional of his parish church, St. Peters in New York City, to confess to God that he had knowingly received stolen goods. Under the tenets of his Roman Catholic faith, Philips had to make oral confession of his sins and perform appropriate penance before he could partake of holy communion. Under centuries-old church doctrines, he could be confident that his confession would remain between him and God -

* Professor of Law, University of Chicago. The author gratefully acknowledges financial support during the preparation of this paper from the Lynde and Harry Bradley Foundation, the helpful comments of Albert Alschuler, Akhil Amar, Jay Bybee, Gerhard Casper, Thomas J. Curry, Richard Fallon, Edward Gaffney, Richard Helmholz, Stephen Holmes, Douglas Laycock, Ira Lupu, Martin Marty, Henry Monaghan, Michael Paulsen, Richard Posner, Frederick Schauer, Cass Sunstein, and Mark Tushnet, and the research assistance of George Sanders and Adam Wolfson. 
that the priest would not reveal to anyone what he had to say. After Philips confessed his crime, the priest, Father Kohlmann, insisted that he return the goods to their rightful owner. Under cover of confidentiality of the confessional, Philips brought the goods to Father Kohlmann, who delivered them to the owner, James Keating. Keating informed the authorities of these events, who in turn subpoenaed Father Kohlmann to appear before the grand jury to identify those responsible for the crime. The priest appeared before the court but pleaded in these words to be excused from testifying:

[I]f called upon to testify in quality of a minister of a sacrament, in which my God himself has enjoined on me a perpetual and inviolable secrecy, I must declare to this honorable Court, that I cannot, I must not answer any question that has a bearing upon the restitution in question; and that it would be my duty to prefer instantaneous death or any temporal misfortune, rather than disclose the name of the penitent in question. For, were I to act otherwise, I should become a traitor to my church, to my sacred ministry and to my God. In fine, I should render myself guilty of eternal damnation. ${ }^{1}$

To this, the district attorney responded:

[T]he constitution has granted religious "profession and worship" to all denominations, "without discrimination or preferance": but it has not granted exemption from previous legal duties. It has expelled the demon of persecution from our land: but it has not weakened the arm of public justice. Its equal and steady impartiality has soothed all the contending sects into the most harmonious equality, but to none of them has it yielded any of the rights of a well organized government. ${ }^{2}$

Thus was posed an issue that continues to divide and trouble the legal system: does the freedom of religious exercise guaranteed by the constitutions of the states and United States require the government, in the absence of a sufficiently compelling need, to grant exemptions from legal duties that conflict with religious obligations? Or does this freedom guarantee only that religious believers will be governed by equal laws, without discrimination or preference?

The New York court in People v. Philips ruled that an exemption was constitutionally required. ${ }^{3}$ Although the government had a legit-

1 This speech and all the other details of the case are taken from a report of the trial published as W. SAMPson, The Catholic Question IN AMERICA 8-9 (I8I3 and photo. reprint 1974). The decision of the court is excerpted in Privileged Communications to Clergymen, I CATH. LAW. I99, I99-209 (1955).

2 W. SAMpson, supra note $\mathrm{I}$, at $5 \mathrm{I}$ (emphasis omitted and punctuation altered). The internal quotations are from N.Y. CONST. of 1777 , art. XXXVIII, reprinted in 2 FEDERAL AND STATE Constitutions, Colonial Charters, and Other Organic Laws of the United States 1328, I338 (B. Poore 2d ed. 1878) [hereinafter FEDERAL AND State Constitutions].

3 See W. SAMPSON, supra note I, at II2-I4. 
imate need and the authority to compel testimony, that need did not outweigh the interference with the relationship between priests and penitents in the Roman Catholic Church. This resolution of the conflict between generally applicable law and religious conscience had deep roots in the practices of the American states both before and after independence. But it was not until the full flowering of the Warren Court that the United States Supreme Court so interpreted the free exercise clause of the first amendment. In the meantime, the Court had upheld enforcement of anti-polygamy laws against Mormons ${ }^{4}$ of child labor laws against a minor who wished to distribute religious tracts in the company of her aunt, 5 of a public university's suspension of students who refused on account of their religious convictions against war to participate in ROTC, ${ }^{6}$ and of Sunday closing laws against Orthodox Jews who observed the Sabbath on Saturday rather than Sunday. ${ }^{7}$

In Sherbert $v$. Verner, ${ }^{8}$ the first and leading case in the Supreme Court's modern free exercise jurisprudence, the Court held that a Seventh-Day Adventist need not agree to work on Saturday in order to be eligible for unemployment compensation. Although a state has a legitimate need and the authority to limit unemployment benefits to those who make themselves available for work, it may not enforce the limitation when it conflicts with sincere religious practices. The state is "constitutionally compelled to carve out an exception - and to provide benefits - for those whose unavailability is due to their religious convictions," as Justice Harlan disapprovingly put the point in dissent. 9 The Sherbert decision thus created the potential for challenges by religious groups and individual believers to a wide range of laws that conflict with the tenets of their faiths, because such laws impose penalties either for engaging in religiously motivated conduct or for refusing to engage in religiously prohibited conduct. For example, in the same year that the Court decided Sherbert, it remanded for reconsideration in light of Sherbert the contempt conviction of a religious objector who refused jury service. ${ }^{10} \mathrm{~A}$ decade later, the

\footnotetext{
4 See Reynolds v. United States, 98 U.S. 445 (1879) (upholding the criminal conviction of a Mormon leader for the crime of polygamy under territorial law); see also Cleveland v. United States, 329 U.S. I4 (1946) (upholding the conviction of a "fundamentalist" Mormon polygamist under a federal statute prohibiting the transportation of a woman across state lines for immoral purposes); Davis v. Beason, 133 U.S. 333 (1890) (upholding the requirement that voters take an oath that they are not members of an organization that teaches polygamy); $c f$. The Late Corp. of the Church of Jesus Christ of Latter-Day Saints v. United States, I36 U.S. I (I890) (upholding a statute revoking the charter of the Mormon Church and confiscating its property).

5 See Prince v. Massachusetts, 321 U.S. 158 (1944).

6 See Hamilton v. Regents of the Univ. of Cal., 293 U.S. 245 (1934).

7 See Braunfeld v. Brown, 366 U.S. 599 (196I).

8374 U.S. 398 (I963).

9 Id. at 420 (Harlan, J., dissenting) (emphasis in original).

${ }^{10}$ See In re Jenison, 375 U.S. 14 (per curiam), vacating and remanding In re Jenison
} 
Court exempted members of the Old Order Amish and the Conservative Amish Mennonite churches from compulsory education of children beyond the age of sixteen. ${ }^{11}$ Free exercise litigation since Sherbert has consisted almost entirely of requests for exemption rather than for general invalidation of restrictive laws. ${ }^{12}$

The Court made no effort in Sherbert or subsequent cases to support its holdings through evidence of the historical understanding of "free exercise of religion" at the time of the framing and ratification of the first amendment. This evident lack of historical support has made the decisions vulnerable to attack. Critics have not hesitated to call the decisions "a palpable and unprecedented misconstruction of the Constitution," at variance with the Lockean liberal principles of the Founding. ${ }^{13}$

While in retrospect the Court's inattention to original meaning may seem characteristic of this period of constitutional jurisprudence, it was anything but characteristic of the Court's treatment of the establishment clause. For example, in the School Prayer Cases decided in the same Term as Sherbert, the author of the Sherbert opinion, Justice Brennan, undertook a lengthy historical analysis of school prayer and public education. He commented that "the line we must draw between the permissible and the impermissible is one which accords with history and faithfully reflects the understanding of the Founding Fathers."14 Interpretations of the establishment clause, then as well as now, are replete with extensive analyses of the historical context and meaning. Indeed, it has been said that "[n]o provision of the Constitution is more closely tied to or given content by its generating history than the religious clause of the First Amendment."15 Yet neither Sherbert nor any other Supreme Court opinion - majority, concurring, or dissenting - has ever grounded the interpretation of the free exercise clause in its historical meaning.

Academic commentary has followed a similarly ahistorical approach. While scores of law review articles and a number of scholarly

Contempt Proceedings, 265 Minn. 96, I20 N.W.2d 515 (1963). On remand, the Supreme Court of Minnesota reversed the conviction. See In re Jenison Contempt Proceedings, 267 Minn. 136, I25 N.W.2d 588 (1963).

11 See Wisconsin v. Yoder, 406 U.S. 205 (1972).

12 The only clear exception among Supreme Court free exercise cases is McDaniel v. Paty, 435 U.S. 618 ( 1978$)$, which struck down a state law prohibiting ministers from serving as delegates to a constitutional convention. Cf. Widmar v. Vincent, 454 U.S. 263 (I98I) (striking down under the free speech clause the exclusion of a student religious group from public university facilities).

13 W. Berns, The First Amendment and the Future of American Democracy 38 , 43-44 (1985).

14 School Dist. v. Schempp, 374 U.S. 203, 294 (I963) (Brennan, J., concurring).

15 Everson v. Board of Educ., 330 U.S. I, 33 (I947) (Rutledge, J., dissenting); accord McGowan v. Maryland, 366 U.S. 420, 437-42 (196r). 
books have been devoted to the historical background of the establishment clause, ${ }^{16}$ little or no scholarly work has been devoted primarily to the history of the concept of "free exercise of religion."17 The history of the free exercise principle is usually seen as too meager, or too inconclusive, to be of much help. ${ }^{18}$ The few serious efforts to examine the history have concluded that the principle of constitutionally compelled free exercise exemptions from generally applicable laws is historically unsupportable. ${ }^{19}$

This Article analyzes the major philosophical, legal, and historical sources that preceded the free exercise clause of the first amendment to determine the probable understanding of those who drafted and

16 See, e.g., C. Antieau, A. Downey \& E. Roberts, Freedom From Federal Establishment (1964); G. Bradley, ChURCh-State Relationships in America (1987); R. CoRd, Separation of Church and State: Historical Fact and CuRrent Fiction (ig82); L. Levy, The Establishment Clause (1986); Laycock, "Nonpreferential" Aid to Religion: A False Claim About Original Intent, 27 WM. \& MARY L. Rev. 875 (1986); Smith, Getting Off on the Wrong Foot and Back On Again: A Reexamination of the History of the Franing of the Religion Clauses of the First Amendment and a Critique of the Reynolds and Everson Decisions, 20 WAKE FOREST L. REV. 569 (1984); Smith, Separation and the "Secular": Reconstructing the Disestablishment Decision, 67 TEx. L. REv. 955 (1989) [hereinafter Smith, Separation and the "Secular"].

17 The most comprehensive studies of the history of religious freedom in the United States to the time of the Constitution have been S. CoBb, ThE RISE of RELigious LiberTy iN America (igoz); and T. Curry, The First Freedoms: Church and State in America to the Passage of the First Amendment (1986). This Article makes liberal use of material from Curry and Cobb. Other useful recent general historical studies include W. MiLler, ThE FIRST LiberTy (I986); Adams \& Emmerich, A Heritage of Religious Liberty, I37 U. PA. L. REV. 1559 (1989); and Kurland, The Origins of the Religion Clauses of the Constitution, 27 WM. \& MARY L. REv. 839 (1986). None of these histories provides a clear doctrinal analysis of the free exercise clause or focuses on free exercise exemptions.

The best historical examination of free exercise exemptions is a little-noticed report to the Attorney General. See Office of Legal Policy, Dep't of Justice, Report to the AtTorNEY GENERAL: RELIGIOUS LIBERTY UNDER THE FREE EXERCISE ClaUSE (1986) [hereinafter REPORT TO THE ATTORNEY GENERAL]. The report relies on a much narrower range of sources than are relied upon in this Article. Moreover, although it reaches conclusions on some issues parallel to those reached here, the report reaches contrary conclusions on other, quite important questions of interpretation. Other significant historical examinations of the exemptions issue include W. BERns, supra note I3; M. MALBIN, RELigion and Politics: The Intentions of THE AUthors of THE First Amendment (1978); and Marshall, The Case Against the Constitutionally Compelled Free Exercise Exemption (1989) (unpublished manuscript) (on file at the Harvard Law Library) (forthcoming in 40 CASE W. RES. L. REV. 357 (1989-1990)). These works reach conclusions at odds with those of this Article and will be discussed throughout at appropriate points.

18 See, e.g., Choper, The Religious Clauses of the First Amendment: Reconciling the Conflict, 4I U. Pirt. L. REv. 673, 676 (1980); Pepper, Reynolds, Yoder, and Beyond: Altematives for the Free Exercise Clause, I98I UTAH L. REv. 309, 315; Marshall, supra note 17.

${ }^{19}$ See W. BERns, supra note I3; M. MALBIN, supra note 17; Marshall, supra note 17 ; see also REPORT TO THE ATTORNEY GENERAL, supra note I7 (arguing that free exercise exemptions are limited to prohibitory law). 
ratified it. The focus is on exemptions from generally applicable laws, since this has posed the most important interpretive issue. The conclusions of this analysis are (I) that exemptions were seen as a constitutionally permissible means for protecting religious freedom, (2) that constitutionally compelled exemptions were within the contemplation of the framers and ratifiers as a possible interpretation of the free exercise clause, and (3) that exemptions were consonant with the popular American understanding of the interrelation between the claims of a limited government and a sovereign God. While the historical evidence may not be unequivocal (it seldom is), it does, on balance, support Sherbert's interpretation of the free exercise clause. ${ }^{20}$

For purposes of this Article, there is no need to presuppose agreement about an "originalist" (or any other) theory of constitutional interpretation. Even opponents of originalism generally agree that the historical understanding is relevant, even if not dispositive. Much of the criticism of the Sherbert doctrine is based on the supposed weakness of its historical roots. ${ }^{21}$ Thus, even if the original understanding of the free exercise clause is not considered dispositive, a fresh look at the historical record can correct misconceptions that have arisen from the ahistorical manner in which free exercise exemptions have been created and defended.

After a brief description of the state of modern free exercise doctrine in Part I, the Article proceeds chronologically. Part II canvasses the preconstitutional history of free exercise of religion in the American colonies and states by analyzing protections found in charters, constitutions, and statutes. This Part also discusses the works of the main philosophical, political, and religious figures of the time and examines actual controversies over free exercise exemptions. Part III discusses the framing of the free exercise clause of the first amendment, as well as early interpretations of free exercise clauses in both federal and state constitutions. Part IV, the conclusion, describes the relation between religion and government that best reflects the original conception of free exercise of religion.

While much of the analysis focuses on the specific doctrinal question of free exercise exemptions, this discussion has implications for the broader controversy involving the proper relationship between law

20 This does not mean that the principle was necessarily correctly applied to the facts of Sherbert. For an analysis of whether there was a burden on free exercise in Sherbert, see McConnell \& Posner, An Economic Approach to Issues of Religious Freedom, 56 U. CHI. L. REV. I, 40-4I (I989).

21 See, e.g., W. BERns, supra note I3; M. MALBIN, supra note I7; Bork, The Supreme Cottrt and the Religion Clauses, in "Turning the Religion Clauses on Their Heads": Proceedings of the National Religious Freedom Conference of the Catholic LEAGUE FOR RELIGIOUS AND CIVIL RIGHTS 83, 85-86 (1988). 
and religious obligation in a liberal republic. ${ }^{22}$ On many levels, the legal recognition of religion as a counter-authority to law is anomalous. Religious freedom claims present paradoxical combinations of duty and liberty, neutrality and special accommodation. The characteristic tendency of the modern legal system has been to assimilate the freedom of religion into the more familiar framework of Lockean liberal individualism. This denies the singularity of religion in life and, more particularly, in political life. Under this view the religion clauses of the first amendment become an instrument of secularism to be interpreted in secular terms. ${ }^{23}$ An understanding of the historical roots of free exercise exemptions casts doubt on this interpretation. It suggests instead a peculiarly American conception of the relation between religion and government - one that emphasizes the integrity and diversity of religious life rather than the secularism of the state.

A robust principle of liberty of conscience also conflicts with the alternative, nonliberal understanding of the governmental role, known as republicanism, under which the state has a responsibility to promote civic virtue among its citizens. The principle of free exercise of religion effectively removes government from the development and transmission of virtue at its most fundamental level - thus devolving upon voluntary religious societies (including those of atheists or agnostics) the central function thought by "republicans" to be vested in the state. The free exercise principle therefore suggests that modern attempts to understand the Founding as a clash between "liberal" and "republican" elements are radically incomplete. It points instead toward a social order that is neither strictly individualistic nor statist in its understanding of the good.

\section{Free Exercise Doctrine Today}

The basic framework of the free exercise exemptions doctrine is easily stated. If the plaintiff can show that a law or governmental practice inhibits the exercise of his religious beliefs, ${ }^{24}$ the burden shifts to the government to demonstrate that the law or practice is necessary to the accomplishment of some important (or "compelling") secular objective and that it is the least restrictive means of achieving that

22 The Article is mostly confined to issues of individual conscience. This is not to disparage the importance of the institutional or corporate aspects of religious exercise - the independence of religious bodies from government control. But the theoretical and historical background for those issues is sufficiently distinct that to combine them would add too much both to pages and to confusion.

${ }^{23}$ See Smith, Separation and the "Secular", supra note 16, at 975-10r5.

${ }^{24}$ For analysis of the requisite "burden" on free exercise, see Lupu, Where Rights Begin: The Problem of Burdens on the Free Exercise of Religion, 102 HaRv. L. REv. 933 (1989); and McConnell \& Posner, cited above in note 20, at 38-45. 
objective. ${ }^{25}$ If the plaintiff meets his burden and the government does not, the plaintiff is entitled to exemption from the law or practice at issue. In order to be protected, the claimant's beliefs must be "sincere," but they need not necessarily be consistent, coherent, clearly articulated, or congruent with those of the claimant's religious denomination. ${ }^{26}$ "Only beliefs rooted in religion are protected by the Free Exercise Clause"; ${ }^{27}$ secular beliefs, however sincere and conscientious, do not suffice. ${ }^{28}$

Some twenty-five years after Sherbert, the legitimacy of this doctrine has increasingly come under attack, and the survival of the principle of free exercise exemptions is very much in doubt. Since I972, the Court has rejected every claim for a free exercise exemption to come before it, ${ }^{29}$ outside the narrow context of unemployment benefits governed strictly by Sherbert. ${ }^{30}$ What once appeared to be a jurisprudence highly sympathetic to religious claims now appears virtually closed to them. Chief Justice Rehnquist and Justice Stevens have openly declared their opposition to the doctrine. Chief Justice Rehnquist has contended that when "a State has enacted a general statute, the purpose and effect of which is to advance the State's

25 For analysis of the "compelling governmental interest," see Gottlieb, Compelling Governmental Interests: An Essential but Unanalyzed Term in Constitutional Adjudication, 68 B.U.L. REV. 9I7 (I988); and McConnell \& Posner, cited above in note 20, at 45-54.

${ }^{26}$ See Frazee v. Illinois Dep't of Employment Sec., rog S. Ct. x5 I4, 1517-I8 (I989); Thomas v. Review Bd., 450 U.S. 707, 715-16 (I981). For critical appraisals of the sincerity requirement, see Noonan, How Sincere Do You Have To Be To Be Religious?, I988 U. IlL. L. REv. 713; and Marshall, supra note 17 , at $27-30$.

27 Frazee, I09 S. Ct. at 1517 (quoting Thomas v. Review Bd., 450 U.S. at 713); see also Wisconsin v. Yoder, 406 U.S. 205, 215-16 (1972) (exempting Amish children beyond the age of 16 from compulsory public school attendance on account of religious beliefs).

28 See, e.g., Africa v. Pennsylvania, 662 F.2d I025 (3d Cir. 198I) (upholding a prison's refusal to provide a prisoner with a special diet on the ground that his belief system was not a religion); United States v. Kuch, 288 F. Supp. 439 (D.D.C. 1968) (rejecting a free exercise claim for exemption from a prohibition on marijuana use on the ground that the defendant did not demonstrate that her beliefs supporting drug use were religious). The historical basis for this limitation is discussed at pp. 1488-1500 below.

${ }^{29}$ See, e.g., O'Lone v. Estate of Shabazz, 482 U.S. 342 (1987) (rejecting the claim of Muslim prisoners seeking a change in work schedule to accommodate Friday worship services); Goldman v. Weinberger, 475 U.S. 503 (I986) (rejecting the claim of an Orthodox Jewish Air Force officer forbidden to wear a yarmulke while on duty and in uniform); Tony \& Susan Alamo Found. v. Secretary of Labor, $47 \mathrm{I}$ U.S. 290 (1985) (requiring members of a religious organization opposed to receiving cash wages to submit to minimum wage regulation); Bob Jones Univ. v. United States, 46r U.S. 574 (1983) (upholding a denial of religious school tax exempt status because of the university's religiously based rule against interracial dating and marriage); United States $\mathbf{v}$. Lee, 455 U.S. 252 ( 1982 ) (requiring members of a self-supporting religious group to contribute to Social Security in violation of their religious tenets).

${ }^{30}$ The narrow holding of Sherbert, as it applies to unemployment benefits, has been repeatedly reaffirmed, most recently in the unanimous Frazee decision. In Hobbie v. Unemployment Compensation Appeals Commission, 480 U.S. I36 (1987), and Thomas v. Review Board, 450 U.S. 707 (198I), then-Justice Rehnquist was the sole dissenter. 
secular goals, the Free Exercise Clause does not . . . require the State to conform that statute to the dictates of religious conscience of any group." 31 Justice Stevens has stated that there is "virtually no room for a 'constitutionally required exemption' on religious grounds from a valid ... . law that is entirely neutral in its general application."32 Several leading scholars in the field have espoused a similar position. ${ }^{33}$

The debate over free exercise exemptions hinges on two different conceptions of the threat government poses to religious liberty. Under the no-exemptions view, the free exercise clause exists solely to prevent the government from singling out religious practice for peculiar disability. The evil to be prevented is, in Judge Bork's words, "laws that directly and intentionally penalize religious observance." 34 The remedy is to strike down the offending legislation and to treat religious institutions and practices the same way that comparable nonreligious institutions and practices are treated. Under the exemptions view, on the other hand, the free exercise clause protects religious practices against even the incidental or unintended effects of government action. The evil includes not only active hostility, but also majoritarian presuppositions, ignorance, and indifference. The remedy generally is to leave the government policy in place, but to carve out an exemption when the application of the policy impinges on religious practices without adequate justification.

Under both conceptions, it is unconstitutional for the government to inflict penalties on religious practices as such. For example, zoning ordinances disallowing churches while allowing meeting halls and other uses with comparable effects are unconstitutional,"35 as are "anticult" legislation, ${ }^{36}$ laws barring clergy from public office, ${ }^{37}$ and charitable solicitation regulations crafted to disadvantage a particular religious sect. ${ }^{38}$ Under the no-exemptions view, however, religious believers and institutions cannot challenge facially neutral legislation, no matter what effect it may have on their ability or freedom to practice

31 Thomas v. Review Bd., 450 U.S. at 723 (Rehnquist, J., dissenting).

32 United States v. Lee, 455 U.S. at 263 (Stevens, J., concurring).

${ }^{33}$ In addition to the sources cited in note $\mathrm{I} 7$ above, see P. KuRLAND, RELigion AND THE LAW (I962); Kurland, The Irrelevance of the Constitution: The Religion Clauses of the First Amendment and the Supreme Court, 24 VILL. L. REv. 3 (1978); and Tushnet, "Of Church and State and the Supreme Court": Kurland Revisited, I989 Sup. CT. REv. 373.

34 Bork, supra note 21 , at 84 .

35 See Hollingsworth v. State, 37 Tenn. 518 (I858); $c f$. Catholic Bishop v. Kingery, 371 Ill. 257,20 N.E.2d 583 (1939) (holding that a city may not zone out religious schools if it allows public schools).

36 See Aronin, Cults, Deprogramming, and Guardianship: A Model Legislative Proposal, 7 Colum. J.L. \& Soc. Probs. 163, 201 n.258 (1982).

${ }^{37}$ See McDaniel v. Paty, 435 U.S. 6 I8 (1978).

38 See Larson v. Valente, 456 U.S. 228 ( 1982 ) (disallowing solicitation regulations under the establishment clause rather than the free exercise clause). 
their religious faith. Thus, a requirement that all witnesses must testify to facts within their knowledge bearing on a criminal prosecution - the requirement at issue in Philips - if applied without exception, could abrogate the confidentiality of the confessional. Similarly, a general prohibition of alcohol consumption could make the Christian sacrament of communion illegal, uniform regulation of meat preparation could put kosher slaughterhouses out of business, and prohibitions of discrimination on the basis of sex or marital status could end the male celibate priesthood.

Both the exemption and no-exemption views can be expressed in terms of "neutrality" toward religion, but the way in which the two views define "neutrality" differs. ${ }^{39}$ Under the no-exemption position, a law or government practice is "neutral" if it makes no reference to religion and has a secular justification unrelated to the suppression of religion. Under the exemption position, a law or governmental practice is not "neutral" if it embodies the majority's view on a contested question of religious significance to the minority, even if that question is of no religious significance to the majority. ${ }^{40}$ For example, from the majority's perspective, a requirement that those seeking unemployment benefits be willing to work on Saturday seems secular and neutral. Only from the perspective of a sabbatarian do Saturday work environments have a religious dimension. Both the exemption and no-exemption views thus insist on neutral, "secular" laws and governmental practices, but the no-exemption view makes that judgment exclusively according to the perspective of the government, while the exemption view takes the perspective of the religious claimant, as well as the countervailing interests of the government, into account.

Likewise, these two interpretations agree that laws and governmental practices must be neutral among religions, but they differ about how this is to be accomplished. Under the no-exemption position, the best way to ensure equal treatment of all religions is to deny exemptions to all. The proponents of exemption, by contrast, observe that powerful and influential religions will usually receive adequate protection in the political arena. ${ }^{41}$ One rarely sees laws that force main-

${ }^{39}$ See Laycock, Formal, Substantive, and Disaggregated Neutrality Toward Religion, 39 DE PAUL L. REv. (forthcoming I 990 ).

${ }^{40}$ Here the term "majority" is used not in the technical sense of comprising over $50 \%$ of the population, but in the sense of prevailing in the political process, and the term "minority," in the sense of losing in the political process. Obviously, "majorities" in the technical sense sometimes lose, and "minorities" sometimes win.

41 See, e.g., Volstead Act, 4I Stat. 305, 308-39 (I9r9), repealed by U.S. CoNST. amend. 2 I (1933) (exempting sacramental wine from prohibition); Civil Rights Restoration Act, 20 U.S.C. $\S \mathrm{I} 68 \mathrm{I}(3)$ (1988) (exempting religious institutions); Nation's Capital Religious Liberty and Academic Freedom Act (Armstrong Amendment), Pub. L. No. 100-462, § 145, 102 Stat. 2269 (1988) 
stream Protestants to violate their consciences. Judicially enforceable exemptions under the free exercise clause are therefore needed to ensure that unpopular or unfamiliar faiths will receive the same consideration afforded mainstream or generally respected religions by the representative branches.

Opposition to free exercise exemptions arises from two jurisprudentially distinct positions. The first looks to the constitutionally required separation of powers and is grounded in a philosophy of judicial restraint. This objection holds that courts are not the proper institutions to craft exemptions from generally applicable statutes that have a secular purpose and lack an intent to suppress religious freedom. Any exemptions must be made by the legislature or by executive officials acting within their delegated authority. The opinions of Chief Justice Rehnquist exemplify this position on the modern Court. The second objection, most forcefully articulated on the modern Court by Justice Stevens, argues that whether made by courts or legislatures, exemptions directed to religion alone are generally unwarranted because determining the "sincerity" of religious claimants is dangerously intrusive, because granting exemptions for religious beliefs discriminates against secular beliefs, and because "special treatment" may give the appearance of aid to and endorsement of religion. While these two positions lead to virtually identical results in free exercise cases, they lead to opposite results in many cases involving the establishment clause, in which legislative exemptions and accommodations are at issue. ${ }^{42}$

As this Article went to press, a five-Justice majority abandoned the free exercise exemptions doctrine except in cases involving a free exercise claim "in conjunction with other constitutional protections." 43 The historical record casts doubt on this interpretation of the free exercise clause.

(exempting Georgetown University from a Washington D.C. law prohibiting discrimination on the basis of sexual preference).

42 See, e.g., Texas Monthly, Inc. v. Bullock, Iog S. Ct. 890 (Ig8g) (striking down a statute exempting religious magazines from sales tax) (Stevens, J., in the majority and Rehnquist, C.J., dissenting); Estate of Thornton v. Caldor, Inc., 472 U.S. 703 (1985) (striking down a statute providing Sabbath observers the right not to work on their chosen Sabbath in the private workplace) (Stevens, J., in the majority and Rehnquist, J., dissenting). Even Justice Stevens sometimes votes to uphold a legislative accommodation specifically tailored to religion. See, e.3., Corporation of the Presiding Bishop of the Church of Jesus Christ of Latter-Day Saints v. Amos, 483 U.S. 327 ( 1987 ) (upholding a statutory exemption for religious organizations from the prohibition of employment discrimination on the basis of religion).

43 Employment Div. v. Smith, No. 88-1213, slip op. at 8 (U.S. Apr. 17, 1990) (1990 U.S. LEXIS $202 \mathrm{I}, * \mathbf{}$ 6). 


\section{Free Exercise Before the Constitution}

Although the free exercise and establishment clauses were proposed in I789 and ratified in I79I, the American states had already experienced I5O years of a higher degree of religious diversity than had existed anywhere else in the world. They had, moreover, seen the results of religious conflict in England and of a variety of approaches to church-state relations in the colonies, ranging from near-theocracy to religious pluralism to state domination of the church. If the states can serve as "laboratories of democracy," 44 the American colonies surely served as laboratories for the exploration of different approaches to religion and government. The free exercise clause cannot be understood or appreciated without knowing what happened before.

\section{A. Four Approaches to Church-State Relations in the Colonies}

The English legacy was not a happy one. During the early settlement of the colonies in the seventeenth century, England suffered from chronic religious strife and intolerance. ${ }^{45}$ The Church of England was the established church of the realm, and both Roman Catholicism and extreme Protestantism (of which Puritanism was the most prominent element) were suppressed. After the deposition of Charles I in the English Civil War, the Protestant dissenters assumed power, and Parliament took it upon itself to rewrite the prayer book and confession of faith, dissolve the episcopal structure of the Church, and confiscate the property of the bishoprics. Parliament ostensibly guaranteed free exercise of religion to most Protestants but denied religious freedom to "papists, the adherents of prelacy and the advocates of 'blasphemous, licentious or profane' doctrines." 46 Baptist leaders were imprisoned, and ministers who insisted on frequent use of the prayer book were ejected from clerical office. ${ }^{47}$

Upon restoration of the monarchy in I66o, Parliament reconstituted the Church of England. Suspected of conspiring with France or Spain to the detriment of England's Protestant rulers, Catholics continued to be targets for hostile legislation, as much for political as for religious reasons. But Protestant dissenters' rights were limited as well. The Test Act of 1672,48 for example, restricted public and military office to Anglicans. The Act also required officeholders to

44 New State Ice Co. v. Liebmann, 285 U.S. 262, 3 II (I932) (Brandeis, J., dissenting).

45 For a discussion of religious strife in England during this period, see F. Makower, THE Constitutional History and Constitution of the Church of ENgland 68-95 (1895 and photo. reprint 1972).

${ }^{46} \mathrm{Id}$. at 86.

${ }^{47} \mathrm{See}$ id. at 85-86.

48 r672, 25 Car. 2, ch. 2. 
swear an oath in court denying transubstantiation and acknowledging the King's supremacy over the Church and to present proof that they had taken communion within the preceding year in accordance with the rites of the Church of England. ${ }^{49}$ The Toleration Act of $1688^{50}$ ended official persecution of Protestant dissenters but left the favored position of Anglicans unchanged. The anti-Catholic elements of the Test Act persisted throughout the eighteenth century.

The English religious policy did not automatically extend to the colonies, where four different approaches to church-state relations developed. The settlers of New England (outside of Rhode Island) were predominantly English Calvinists called "Puritans" or "Congregationalists." They moved to the wilderness of the New World in order to establish a Christian commonwealth where, for the first time in history, society would be directed by the revealed word of God. Both civil and church governance were established in accordance with their "congregational" understanding of church polity, under which each town would constitute a congregation and would select its own minister (within certain standards of education set by the General Court) and would maintain a minister and church through compulsory taxes. Authority in the system was decentralized and genuinely democratic, but the results were foreordained. The local churches were invariably of the Congregationalist persuasion. Nonetheless, ministers in the system were accorded a high degree of autonomy from civil control, and indeed frequently lectured colonial authorities on their civic and spiritual derelictions. 51

Having carved their communities out of the rocky wilderness of a distant land, the Puritans of New England saw no reason to allow ungodly individuals to spoil their vision of a Christian commonwealth. This vision allowed no room for religious pluralism or even for toleration. "Polipiety [a variety of sects] is the greatest impiety in the world," according to a well-known tract by Nathaniel Ward.52 The great preacher John Cotton declared that "it was Toleration that made the world anti-Christian."53 Cotton reasoned:

Fundamentals are so cleare, that a man cannot but be convinced in Conscience of the Truth of them after two or three Admonitions: and that therefore such a Person as still continues obstinate, is condemned of himselfe: and if he then be punished, $\mathrm{He}$ is not punished for his Conscience, but for sinning against his owne Conscience. ${ }^{54}$

${ }^{49}$ See id.

50 I W. \& M., ch. I8.

51 For a general discussion of church-state relations in New England during this period, see I W. McLoughlin, NeW ENGLANd Dissent: 1630-I833, at 3-I10 (1971).

$52 \mathrm{~S}$. COBB, supra note $\mathrm{I}$, at 68 (quoting N. WARD, The Simple Cobler of Aggawam IN AMERICA (4th ed. I647 and photo. reprint I905)).

53 Id.

${ }^{54} \mathrm{~J}$. Cotton, The Bloudy Tenent Washed 9 (London 1647 \& photo. reprint 1972). 
Massachusetts, the most rigorous of the New England Congregationalist establishments, actively persecuted dissenters. Baptists were banished from the colony by statute in $1644,{ }^{55}$ and four Quakers, who insisted on returning after being expelled, were hanged. ${ }^{56}$ Other dissenters were horsewhipped or jailed. By the I680's, these violent measures came to an end, although the established church and the hostility to religious diversity continued in New England well into the nineteenth century. 57

By contrast, in Virginia the Church of England was established by order of the Crown and maintained, in large part, as an instrument of social control by the governing authorities and the local gentry. The government financed and tightly controlled the Church. Although Virginia and New England both maintained religious establishments, the two systems were in a more profound sense opposites. The New England establishments arose from a grassroots movement born of the conviction that religious truth should control all of society, while the Virginia establishment was imposed from above and dedicated to governmental control over religion.

For the first century of its existence, the Virginia establishment required little overt coercion, for few dissenters ventured into the colony. Even so, ministers sent to serve the small Puritan community in Virginia were expelled, as was the Catholic Lord Baltimore. ${ }^{58}$ As in Massachusetts, harsh measures, including banishment, were authorized against Quakers, but there is little evidence that they were put into effect. ${ }^{59}$ In the eighteenth century, waves of newcomers, first Presbyterians but later Baptists and a few Quakers, entered the colony. The authorities blocked the Presbyterians' ability to preach at every turn, and the Baptists were "reviled" and "met with violence."60 Baptists continued to be horsewhipped and jailed for their preaching until the Revolution. In the eighteenth century, Virginia was the most intolerant of the colonies. ${ }^{61}$

Cotton's position had roots in both the Catholic and Reformed traditions and can be traced to St. Augustine. See, e.g., Letter from Augustine to Boniface, The Correction of the Donatists (A.D. 417), excerpted in J. Noonan, The Believer and the Powers That ARE I9 (1987) (embracing the use of coercion against heretics and schismatics); see also D. RichaRDS, TOLERATION AND THE CONSTITUTION 87-88 (I986) (discussing St. Augustine's views regarding schismatic Christians and heretics).

55 See T. CURRY, supra note $\mathrm{I} 7$, at $\mathrm{I} 2-\mathrm{r} 3$.

56 See id. at 22.

57 See id. at 88.

58 See S. CoBr, supra note 17 , at 82, 84-87.

${ }^{59}$ See id. at 89-90. But $c f$. id. at $9 \mathrm{I}$ (noting that some Quakers were arraigned and fined under Governor Berkeley).

$60 \mathrm{~J}$. Lewis, The Pursuit of Happiness: Family and Values in Jefferson's Virginia 49 (1987). For a discussion of Presbyterian difficulties, see T. CURRX, supra note 17 , at 99; for a discussion of Virginia's persecution of Baptists, see text accompanying note 152 below.

${ }^{61} \mathrm{See} \mathrm{S}$. COBB, supra note I7, at 93, III-I4; T. CURRY, supra note 17 , at $134-35$; R. ISAAC, 
In time, the Virginia system spread to Maryland and throughout the South, though with less violence toward dissenters. Georgia, the last colony to be settled, represents an interesting variation. The Trustees of the Georgia colony firmly supported the established Church of England. With the assistance of the Anglican-based Society for the Propagation of the Gospel, they financed and supervised ministers, built churches, and encouraged attendance and support for religion. ${ }^{62}$ Unlike the Virginians, the Georgia Trustees demonstrated remarkable tolerance toward Protestant dissenters and even toward Jews. (Savannah contained a substantial Jewish community, which was allowed to worship in peace and participate in public affairs.) Catholics, however, were detested and excluded from the colony. ${ }^{63}$

The third approach to religious liberty might be described as benign neglect. In New York and New Jersey, a policy of de facto religious toleration evolved, largely due to the extraordinary religious diversity of the area. Although the four counties of metropolitan New York had a formally established church, and although there were periodic episodes when the royal governor attempted to enforce conformity to the Anglican Church, for the most part Protestants remained free to live and worship in these colonies as they chose, and Quakers and Jews were generally unmolested. ${ }^{64}$

The fourth approach to religious freedom in seventeenth-century America arose in those colonies that were established explicitly as havens for religious dissenters. There were four such foundings, each with a different religious cast. Maryland, the first haven for dissenters, was founded by a Catholic proprietor, George Calvert (the first Lord Baltimore), and his son, Cecil Calvert, to provide a place for English Catholics to escape the persecution they suffered in the mother country. ${ }^{65}$ After I689, however, the proprietor was removed and the Protestant majority in Maryland established the Church of England and initiated a program of discrimination and intolerance toward dissenters, particularly Roman Catholics. In the eighteenth century, Maryland rivaled Virginia for the narrowness and intolerance of its laws. Roger Williams, an extreme Protestant dissenter, founded Rhode Island as a refuge for those who could not endure the Massa-

The Transformation of Virginia 148-54, 162-63, I75-77, 192-94, 198-203 (1982); H. McIlwaine, The Struggle of Protestant Dissenters for Religious Toleration in VIRGinIA (Johns Hopkins Univ. Studies in Hist. and Pol. Sci., 12th Series, No. 4 April, 1894).

62 See R. Strickland, Religion and State in Georgia in the Eighteenth Century 44-92 (I939).

63 See id. at $79-83$.

64 See S. COBB, supra note 17 , at 301-62, 399-418; T. CURRY, supra note 17 , at 62-73.

65 See W. Russell, Maryland: The Land of Sanctuary (2d ed. 1908); Lasson, Free Exercise in the Free State: Maryland's Role in Religious Liberty and the First Amendment, $3 \mathrm{I}$ J. CHURCH \& ST. 4 I9 (I989). 
chusetts establishment. ${ }^{66}$ William Penn founded Pennsylvania and Delaware as sanctuaries for Quakers. ${ }^{67}$ Although each of these colonies was established for the benefit of a particular religious sect, all extended freedom of religion to groups beyond their own. Finally, Carolina was founded by a group of proprietors, with the assistance of John Locke, who followed Enlightenment principles of toleration. ${ }^{68}$ Early in the eighteenth century, North and South Carolina abandoned these principles and instituted a rigid establishment of the Church of England along lines parallel to Virginia's. ${ }^{69}$ It was in these colonies - Maryland, Rhode Island, Pennsylvania, Delaware, and Carolina - that the free exercise of religion emerged as an articulated legal principle.

The term "free exercise" first appeared in an American legal document in I648, when Lord Baltimore required his new Protestant governor and councilors in Maryland to promise not to disturb Christians ("and in particular no Roman Catholic") in the "free exercise" of their religion. ${ }^{70}$ The proprietor had previously attempted to attract settlers from Boston by a promise of "free liberty of religion," to which offer Massachusetts Governor John Winthrop responded that none "of our people ... [had a] temptation that way." "71 In I649, the Maryland Assembly passed a statute containing the first "free exercise" clause on the continent: "noe person . . . professing to beleive in Jesus Christ, shall from henceforth bee any waies troubled . . . for . . . his or her religion nor in the free exercise thereof . . . nor any way [be] compelled to the beliefe or exercise of any other Religion against his or her consent." "72

Rhode Island's Charter of $1663^{73}$ was the first to use the formulation "liberty of conscience." The founder, Roger Williams, was a man of extreme and idiosyncratic religious views who was banished from Puritan Massachusetts. Williams wrote frequently, eloquently, and vituperatively in defense of freedom of conscience. ${ }^{74}$ With a few glaring exceptions (Rhode Island barred Jews from citizenship, a provision that was not abandoned until $1842,{ }^{75}$ and barred Catholics

\footnotetext{
66 See S. CовB, supra note 17 , at $422-23$.

${ }^{67} \mathrm{See}$ id. at $440-4 \mathrm{I}$.

68 See id. at II5-I9.

${ }^{69}$ See id. at 124-26.

$70 \mathrm{~W}$. RuSSELL, supra note 65 , at 130 .

712 J. WINThrop, The HISTORY OF NEW ENGLAND FROM I630-I649, at I49 (I825 and photo. reprint 1972 ).

72 Act Concerning Religion of I649, reprinted in 5 ThE Founders' Constitution 49, 50 (P. Kurland \& R. Lerner eds. I987).

73 R.I. Charter of 1663 , reprinted in 2 Federal and State Constitutions, supra note 2 , at 1595,1596 .

74 His most prominent work, written in 1644 , was R. Williams, The Bloudy Tenent of Persecution, in 3 The Complete Writings of Roger Williams I (S. Caldwell ed. 1963).

75 See M. BORDEN, JEWS, TuRKS, AND INFIDELS 13 (1984).
} 
from public office ${ }^{76}$ ), the colony lived up to its royal Charter of 1663 as a "livelie experiment . . . with a full libertie in religious concernements."77 In I64I, the legislature ordered that "none be accounted a delinquent for doctrine, provided that it be not directly repugnant to the government or laws established."78 This tends to support historian Thomas Curry's statement that "[t]he Rhode Island towns carefully reiterated that liberty of conscience did not exempt one from the civil law."79 Later, the royal Charter of 1663 protected residents of the colony from being "in any wise molested, punished, disquieted, or called into question, for any differences in opinione in matters of religion, and doe not actually disturb the civill peace of our sayd colony," 80 and stated that they may "freelye and fullye have and enjoye his and theire owne judgments and consciences, in matters of religious concernments ... ; they behaving themselves peaceblie and quietlie and not useing this libertie to lycentiousnesse and profanenesse, nor to the civill injurye or outward disturbeance of others." 81 In comparison with the earlier language, this provision implies that believers were not required to obey all "laws established," but only those directed to maintaining the "civill peace" and preventing licentiousness and profaneness, or the injury of others.

It is tempting to assume that other American colonies observed and eventually imitated the vision of Roger Williams and the Rhode Island "experiment," for the depth and breadth of the Rhode Island commitment to religious freedom were unparalleled until after the American Revolution. ${ }^{82}$ The truth, however, is that Williams' writings were lost and forgotten until Massachusetts Baptist apologist and historian Isaac Backus rediscovered them in $I 773 . .^{83}$ In fact, far from being a positive example, Rhode Island was the pariah among the colonies, with a reputation for disorder and instability: "During and after the colonial period, Rhode Island, 'the licentious Republic' and

76 See T. CURRY, supra note $\mathrm{I} 7$, at 90.

77 R.I. Charter of 1663 , reprinted in 2 Federal and State Constitutions, supra note 2 , at 1595,1596 .

$78 \mathrm{~S}$. COBB, supra note $\mathrm{r} 7$, at 430 .

79 T. CuRry, supra note 17 , at 20.

80 R.I. Charter of 1663 , reprinted in 2 Federal and State Constitutions, supra note 2 , at 1595,1596 .

81 Id., reprinted in 2 FEDERAL and STATE Constitutions, supra note 2, at 1597.

${ }^{82}$ For scholarly works taking this approach, see M. HowE, The Garden AND THE WILDERness (1965); P. MilleR, Roger Williams: His Contribution to the AMERICAN TraDItION (I953); W. Miller, cited above in note 17 ; and L. TRIBE, AMERICAN Constitutional LAW \& $14-3$, at $1158-59$ (2d ed. 1988).

${ }^{83}$ See T. CURRY, supra note 17 , at 91 ; see also I W. McLoughLIN, supra note 51 , at 8 ("[A]lmost no one in colonial New England ever praised his experiment, sought his advice, quoted his books, or tried to imitate his practices."). 
'sinke hole of New England,' was an example to be shunned."84 It is unlikely that the Rhode Island provisions had much direct influence on subsequent developments of the free exercise principle.

The language of the Rhode Island Charter of I663, however, had a second and third life elsewhere in the colonies. In I664, the proprietors of Carolina issued an "Agreement" with prospective settlers, using words almost identical to the Rhode Island charter of the previous year, ${ }^{85}$ and two of the Carolina proprietors also obtained the grant of New Jersey, where they promulgated an almost identical provision. ${ }^{86}$ The language of the Rhode Island, Carolina, and New Jersey provisions represented the most common form of protection for religious freedom in the early colonies, although the provisions in other colonies were less expansive. The language did not survive in North Carolina, South Carolina, or New Jersey, as it was superseded by later (and more limited) religious freedom provisions. But the substance of these early provisions later re-emerged as the most common pattern in the constitutions adopted by the states after the Revolution. ${ }^{87}$

Three features of these early provisions warrant attention. First, the free exercise provisions expressly overrode any "Law, Statute or clause, usage or custom of this realm of England to the contrary." 88 Second, they extended to all "judgments and contiences in matters of religion"; 89 they were not limited to opinion, speech and profession, or acts of worship. Third, they limited the free exercise of religion only as necessary for the prevention of "Lycentiousnesse" or the injury or "outward disturbance of others," 90 rather than by reference to all generally applicable laws. As discussed more fully below, these fea-

$84 \mathrm{I} \mathrm{W.} \mathrm{McLoughLIN,} \mathrm{supra} \mathrm{note} 5 \mathrm{I}$, at 8 . This illuminates the irony in the remark by Benjamin Huntington, Representative from Connecticut, during the debate over the religion clauses of the first amendment that "[b]y the charter of Rhode Island, no religion could be established by law; he could give a history of the effects of such a regulation; indeed the people were now enjoying the blessed fruits of it." I ANNALs OF CoNG. 758 (J. Gales ed. I834) (Aug. 15, I789). Huntington opposed the amendment.

Two printings exist of the first two volumes of the Annals of Congress. They contain different pagination, running heads, and back titles. The printing with the running head "History of Congress" conforms to the remaining volumes of the series, while the printing with the running head "Gales \& Seaton's history of debates in Congress" is unique. See CHEcklIst of UNITED States PUblic DoCUMENTS $1789-1909$, at 1463 (3d ed. I9II). All page citations herein are to the latter printing. Readers with the "History of Congress" printing can most easily find parallel citations by referring to the date.

${ }^{85}$ See S. COBB, supra note 17 , at II7.

86 See id. at 400.

${ }^{87}$ For a discussion of the later constitutions, see pp. $1456-57$ \& note 242 below.

$88 \mathrm{~S}$. COBB, supra note $\mathrm{I} 7$, at $\mathrm{II} \%$.

89 Id.

$90 I d$. 
tures are consistent with the idea of free exercise exemptions and indicate the lengthy pedigree of modern exemptions under the free exercise clause of the United States Constitution. ${ }^{91}$

Under the second Charter of Carolina, issued in $1665,{ }^{92}$ the availability of free exercise exemptions was made yet more explicit. Recognizing that "it may happen that some of the people and inhabitants of the said province cannot, in their private opinions, conform" to the Church of England, ${ }^{93}$ the charter authorized the proprietors "to give and grant unto such person and persons ... such indulgences and dispensations, in that behalf" as they "shall, in their discretion, think fit and reasonable."94 "Indulgences" and "dispensations" are technical legal terms, referring to the King's asserted power to exempt citizens from the enforcement of a law enacted by Parliament. Charles II and James II used these powers frequently to exempt Roman Catholics (and sometimes Protestant dissenters) from oppressive laws. ${ }^{95}$ The proprietors used this authority, among other things, to exempt Quakers from the colony's oath requirements and to allow settlements made up of non-Anglicans to choose their own ministers. ${ }^{96}$

In 1669 , the proprietors issued the Fundamental Constitutions, ${ }^{97}$ though it was never fully put into effect. ${ }^{98}$ The Fundamental Constitutions is of particular interest because John Locke, as principal adviser and assistant to Lord Ashley, the most active and influential of the Carolina colony proprietors, helped to draft it. Indeed, the published text was first printed from a copy in Locke's own handwriting and bears an obvious resemblance to Locke's theories of religious toleration. ${ }^{99}$ The Fundamental Constitutions established the Church of England as "the only true and orthodox" church. ${ }^{100}$ Nonetheless, persons of "different opinions concerning matters of religion," other than atheists, were welcomed into the colony. ${ }^{101}$ In a remark-

91 See infra pp. 1461-64.

92 See Carolina Charter of 1665 , reprinted in 2 Federal and State Constitutions, supra note 2 , at $\mathrm{r} 390$.

93 Id., reprinted in 2 Federal and STATE Constitutions, supra note 2, at 1397.

94 Id., reprinted in 2 FEDERAL AND STATE CONSTITUTIONS, supra note 2, at 1397.

95 See J. Kenyon, The Stuart Constitution: Documents and CommentaRy 40I-13 (1966); F. Maitland, The Constitutional History of ENgland 302-o6 (1968); 2 W. StubBs, The Constitumional HistoRy of ENGLAND 581-84 (3d ed. 1887 \& photo. reprint 1987). The English Bill of Rights of 1689 curtailed the royal power of dispensation. See Bill of Rights, 1689, I W. \& M., ch. 2, reprinted in 5 The Founders' Constitution, supra note 72 , at $\mathrm{I}$.

96 See T. CURRY, supra note 17 , at 56.

97 See Fundamental Constitutions of 1669 , reprinted in 2 Federal and State ConSTITUTIONS, supra note 2 , at 1397 .

98 See H. BOURNe, The LIFE OF JoHn Locke 243-44 (1876 and photo. reprint 1969).

99 See id. at 239 \& n.x.

100 Fundamental Constitutions of 1669 , $\S 96$, reprinted in 2 Federal and State Constitutions, supra note 2 , at $1397,1406$.

101 Id. $\S 97$, reprinted in 2 FEDERAL AND STATE Constitutions, supra note 2, at 1406. 
able display of broadmindedness for its day, the document specifically extended protection to "Jews, heathens, and other dissenters from the purity of Christian religion," as well as to the "natives of that place."102 Even slaves were free to select "what church or profession any of them shall think best, and, therefore, be as fully members as any freeman." 103

While the Fundamental Constitutions provided exceptionally broad freedom to choose among religions, there was no freedom of nonreligion or of individualistic, non-institutionalized belief. Atheists were banned from the colony, and every person was required to be enrolled as a member of one (and only one) church. "[A]ny seven or more persons agreeing in any religion, shall constitute a church or profession"104 and could worship without molestation, provided they adhered to three tenets:

Ist. "That there is a God."

II. "That God is publicly to be worshipped."

III. "That it is lawful and the duty of every man, being thereunto called by those that govern, to bear witness to truth; and that every church or profession shall, in their terms of communion, set down the external way whereby they witness a truth as in the presence of God ...."105

Under this system, churches were required to register their membership with the authorities, and any religious assemblies that did not register would "not be esteemed as churches, but unlawful meetings, and be punished as other riots."106 This system suggested a respect for the role of religion in supporting social stability, coupled with an indifference to the choice of religion that is made and a fear of secret religion and private faith. It had the strange effect of simultaneously denying ultimate authority over religious matters to the state, the church, and the individual. This corresponds to no popular conception of church-state relations and perhaps accounts for the system's failure of implementation.

In actual practice, the most influential examples of religious pluralism were the middle colonies, where no church was established (except in the four counties of metropolitan New York) and the widest

102 Id. $\$ 97$, reprinted in 2 FEDERAL AND STATE CONSTITUTIONS, supra note 2, at iq0607.

103 Id. $\S 107$, reprinted in 2 Federal AND STATE Constitutions, supra note 2 , at 1407.

104 Id. $\$ 97$, reprinted in 2 FEderal AND STATE Constitutions, supra note 2, at 140607.

105 Id. $\S 100$, reprinted in 2 FEDERAL AND STATE Constitutions, supra note 2 , at 1407.

106 Id. $\S 108$, reprinted in 2 FEderal and State Constitutions, supra note 2 , at I407. 
range of religious persuasions lived in relative harmony. William Penn's colonies were particularly associated with religious freedom and harmony because of Penn's widely read work, The Great Case of Liberty of Conscience, published in I670. ${ }^{107}$ Under his I7or Charters of Privileges, ${ }^{108}$ Pennsylvania and Delaware protected the religious profession of all theists (but confined public office to Christians). This example caught the eye of statesmen in other colonies, for Pennsylvania's promise of toleration contributed to the highest level of immigration of any of the colonies, and with immigration, prosperity. Madison later contrasted the religious repression of Virginia, which turned away useful settlers, with " $[t]$ he allurements presented by other situations,"109 probably referring to Pennsylvania.

\section{B. Locke and Theories of Religious Toleration}

These variations in the scope of free exercise in pre-revolutionary America paralleled an intense and controversial theoretical debate on the other side of the Atlantic regarding the proper relation between religion and the state. Most of the great political thinkers of the period - among them Hobbes, Bodin, Spinoza, Locke, Hume, Bayle, Voltaire, Montesquieu, Montaigne, Smith, and Burke - contributed to the subject and in some manner, however indirect, influenced the American solution to the problem.

This section concentrates on the thought of John Locke, both because his discussion of the religion question was most extensive and because his influence on the Americans and the first amendment was most direct. Jefferson carefully read and made notes on Locke's The Reasonableness of Christianity 110 and his Letters on Religious Toleration. ${ }^{111}$ Major portions of Jefferson's Bill for Establishing Religious

${ }^{107}$ See W. PENN, The Great Case of Liberty of Conscience, in I A Collection of the WORKS OF WILLIAM PENN 443 (London 1726 and photo. reprint 1974).

108 See Del. Charter of I 70I, reprinted in I Federal and State Constitutions, supra note 2, at 270; Pa. Charter of Privileges of 1701 , reprinted in 2 Federal and State Constitutions, supra note 2 , at $\mathrm{I536}$; see also $\mathrm{S}$. COBB, supra note $\mathrm{I} 7$, at $440-53$ (discussing the religious histories of colonial Pennsylvania and Delaware); T. CuRRY, supra note 17, at 7277, 159-62 (same); Gaustad, Colonial Religion and Liberty of Conscience, in THE VIRGINIA STATUTE For Religious Freedom: Its Evolution and Consequences in AMERICAN HisTORY 35 (M. Peterson \& R. Vaughan eds. 1988) [hereinafter ViRginia STATUTE FOR RELigious FREEDOM] (same).

${ }^{109} \mathrm{~J}$. MAdison, Memorial and Remonstrance Against Religious Assessments, in 2 ThE Writings of JAMES MADison I83, I88 (G. Hunt ed. IgOI) [hereinafter J. Madison, Memorial and Remonstrance]. Memorial and Remonstrance is also reprinted as an appendix to Justice Rutledge's dissenting opinion in Everson v. Board of Education, 330 U.S. I, 28 app. at 63 (I947) (Rutledge, J., dissenting).

$110 \mathrm{~J}$. Locke, The Reasonableness of Christianity (I. Ramsey ed. I958) (Ist ed. 1695).

111 The Letters are reprinted in $6 \mathrm{~J}$. LOCKE, THE WORKS OF JOHN LOCKE (London 1823 and 1963 photo. reprint) [hereinafter WORKS OF LOCKE]. Jefferson's notes appear in T. JEFFerson, Notes on Locke and Shaftesbury, in I THE PAPERS OF THOMAS JEFFERSON 544, 54448, 549-5 I (J. Boyd ed. I950) [hereinafter PAPERS OF JEFFERsoN]. 
Freedom ${ }^{112}$ derived from passages in Locke's first Letter Concerning Toleration. ${ }^{113}$ Jefferson's bill, in turn, was one of the major precursors of the religion clauses of the first amendment. ${ }^{114}$ Four of the five states used language from Jefferson's bill in their proposals for a religion amendment. ${ }^{115}$ Moreover, James Madison served as floor leader in the Virginia assembly in support of Jefferson's bill; only three years later, he would serve as draftsman and floor leader in the House of Representatives in support of the Bill of Rights. Locke's ideas also entered the American debate (though more selectively) through the writings of Massachusetts Baptist apologist Isaac Backus. ${ }^{116}$ Locke's ideas, then, are an indispensable part of the intellectual backdrop for the framing of the free exercise clause. ${ }^{117}$ The ways in which American advocates of religious freedom departed from Locke, however, are as significant as the ways in which they followed him.

John Locke was one of the earliest, and certainly one of the most influential, advocates of religious freedom on a theoretical ground. Writing in the aftermath of religious turmoil in England and throughout Europe, he viewed religious rivalry and intolerance as among the most important of political problems. Religious intolerance was inconsistent both with public peace and with good government. Locke's resolution of the problem involved two elements: a modification of the nature and claims of religion and an abandonment of the government's role in upholding religious truth. His teachings on religion, most prominently in The Reasonableness of Christianity, urged that Christianity be made more rational and tolerant but less engaged in questions of earthly significance. Thus, the dissension among Christian

112 Jefferson, A Bill for Establishing Religious Freedom (June I2, I779), reprinted in 5 THE FOUNDERs' CONSTITUTION, supra note 72 , at 77 .

113 See J. LOCKE, A Letter Concerning Toleration, in 6 WoRKs of LOCKE, supra note III, at I [hereinafter J. LockE, A Letter Concerning Toleration]; Sandler, Lockean Ideas in Thomas Jefferson's Bill for Establishing Religious Freedom, 2 I J. HIST. IDEAS Ioo (r96o); see also W. BERNS, supra note 13 , at I8-24 (tracing the Lockean roots of Jefferson's insistence that principles of consent and free opinion require religious freedom); M. MALBIN, supra note I7, at 29 (noting and summarizing Jefferson's reliance upon the first Letter Concerning Toleration in drafting the Bill for Establishing Religious Freedom); Kessler, Locke's Influence on Jefferson's "Bill for Establishing Religious Freedom," 25 J. CHURCH \& ST. 231 (I983) (cataloging the similarities between Locke's Letters and Jefferson's bill).

114 See Marty, The Virginia Statute Two Hundred Years Later, in Virginla STATUTE for Religious FreEdom, supra note ro8, at I, IO-I I. But cf. C. ANTIEAU, A. Downey \& E. ROBERTs, supra note 16 (explaining the varieties of religious establishment and toleration in the colonies and illustrating the wide range of opinion and practice that lies behind the adoption of the religion clauses); P. KAUPER, RELIGION AND THE CoNSTITUTION 48-50 (I964) (warning against too heavy a reliance on the views of Madison and Jefferson for interpretation of the first amendment).

115 See infra TAN 359-362.

116 See McLoughlin, Introduction, in I. Backus, IsaAc Backus on ChURch, STATE, aNd Calvinism I, 40-44 (W. McLoughlin ed. I968) [hereinafter ChuRCh, State, AND CalviNism].

117 See D. RICHARDS, supra note 54, at 105-10. 
denominations would be softened and would be less likely to create political problems.

Although his little-known earlier works, Two Tracts on Government, ${ }^{118}$ advocated that government reduce religious turmoil by enforcing religious unity, 119 by 1689 Locke had concluded that such attempts were the source of the problem: "It is not the diversity of opinions, which cannot be avoided; but the refusal of toleration to those that are of different opinions, which might have been granted, that has produced all the bustles and wars, that have been in the Christian world, upon account of religion."120 Accordingly, Locke became an advocate of a sweeping toleration toward religious dissenters, with the exceptions of Catholics (because of their allegiance to a foreign prince), atheists (because they cannot be trusted to carry out their promises and oaths), and those who refuse to support tolerance for others. ${ }^{121}$ "Nobody ... . [has] any just title to invade the civil rights and worldly goods of [another], upon pretence of religion," Locke stated. "Those that are of another opinion, would do well to consider with themselves how pernicious a seed of discord and war, how powerful a provocation to endless hatreds, rapines, and slaughters, they thereby furnish unto mankind."122

In Locke's view, religious strife stems from the tendency of both religious and governmental leaders to overstep their bounds and intermeddle in the others' province: "I esteem it above all things necessary to distinguish exactly the business of civil government from that of religion, and to settle the just bounds that lie between the one and the other."123 The proper division between the realms of government and religion comes down to this: "all the power of civil government relates only to men's civil interests, is confined to the care of the things of this world, and hath nothing to do with the world to come,"124 while "churches have [no] jurisdiction in worldly mat-

118 J. Locke, Two Tracts on Government (P. Abrams ed. 1967). Not to be confused with his Two Treatises of Government (P. Laslett rev. ed. 1963) (3d ed. I698), these essays were written by Locke in 1660 , at the age of 30 , but he did not publish them. Both Tracts are devoted to defending the power of the magistrate over religion.

119 Locke's Two Tracts on Government resembled Thomas Hobbes' teaching that civil government should have complete authority over religion, extending not just to conduct but to religious profession and worship as well. See T. Hobbes, Leviathan, pt. III, ch. 43 , at 355 (M. Oakeshott ed. 1957) (Ist ed. I65I). Hobbes denied any right to exemption from civil law on account of religious scruple, both because it would engender "confusion and civil war," id., and because true Christianity required only two "virtues" for salvation: "faith in Christ, and obedience to Laws." Id. at 385 (emphasis in original).

$120 \mathrm{~J}$. LoCKE, A Letter Concerning Toleration, supra note $\mathrm{II}_{3}$, at 53 .

${ }^{121}$ See id. at $46-47$.

$122 \mathrm{Id}$. at 20.

123 Id. at 9.

124 Id. at $12-\mathrm{I} 3$. 
ters."125 Thus, Locke was concerned not only with limiting the powers of government, but also with limiting the purview of religion. "The end of a religious society," he wrote, "is the public worship of God, and by means thereof the acquisition of eternal life. All discipline ought therefore to tend to that end, and all ecclesiastical laws to be thereunto confined." 126

To be sure, Locke's ideal of separation was less than complete, for he was willing to countenance governmental encouragement of the state religion. "[T]he magistrate may make use of arguments," wrote Locke, "and thereby draw the heterodox into the way of truth, and procure their salvation . . . . But it is one thing to persuade, another to command; one thing to press with arguments, another with penalties."127 $\mathrm{He}$ also accepted government financial support of state religion and never condemned the English system of supporting the church with taxes; indeed, he served as secretary to the Lord Chancellor for the presentation of benefices - that is, the dispensing of religious patronage. ${ }^{128}$ While Locke opposed what would be called interference with free exercise, he thus approved of what would be called an establishment under modern constitutional doctrine.

For the purposes of this Article, two aspects of Locke's teaching are particularly significant: his advocacy of legislative supremacy with respect to conflicts between public power and individual conscience and his rejection of religious exemptions. Although Locke's prescription for religious harmony depends upon the division between the religious and the secular jurisdictions, he anticipated that some matters, such as "[m]oral actions," belong "to the jurisdiction both of the .. . magistrate and conscience." $129 \mathrm{He}$ recognized that this creates "great danger, lest one of these jurisdictions intrench upon the other."130 As a practical matter, the possible overlap in jurisdiction did not greatly concern Locke, for "if government be faithfully administered, and the counsels of the magistrate be indeed directed to

125 Id. at 19.

${ }^{126} \mathrm{Id}$. at $15-16$. This understanding has its modern echo in the claim that religion is a strictly "private" matter, which ought not be allowed to influence public decisions. An example of this position, though not using precisely the words in text, is Justice Stevens' opinion in Webster v. Reproductive Health Services, rog S. Ct. 3040 (1989), in which he argues that religiously based premises about the value of life form an illegitimate basis for legislation. See id. at 3082-85 (Stevens, J., concurring in part and dissenting in part). For a critique of this position, see K. Greenawalt, Religious Convictions and Political Choice i2 (I988), which concludes that it is appropriate for citizens and legislators to rely upon their religious convictions when "shared premises of justice and criteria for determining truth cannot resolve critical questions of fact"; and Religion and the State, 27 WM. \& MARY L. REV. 833, IOII1 I 09 (I 986 ).

${ }^{127}$ J. LOCKE, A Letter Concerning Toleration, supra note II3, at II.

128 See I P. King, The Life of John Locke 62 (London I830).

129 J. LOCKE, A Letter Concerning Toleration, supra note II3, at 41 .

$130 \mathrm{Id}$. 
the public good," it will "seldom happen" that the magistrate enjoins "'any thing by his authority, that appears unlawful to the conscience of a private person."'131 In theory, however, such clashes might occur; Locke proposed that under these circumstances the individual should disobey the law and accept punishment from the state. "[T]he private judgment of any person concerning a law enacted in political matters, for the public good, does not take away the obligation of that law, nor deserve a dispensation." 132

Locke gave a modicum of rhetorical support to the individual, exempting from this requirement of obedience those laws "not within the verge of the magistrate's authority."133 But when the magistrate believes that a law is within his authority, and the individual believes the contrary, the magistrate prevails: "Who shall be judge between them? I answer, God alone; for there is no judge upon earth between the supreme magistrate and the people. . . . You will say then the magistrate being the stronger will have his will, and carry his point. Without doubt."134 In other words, the government's perception of public need defines the boundaries of freedom of conscience. As Professor Walter Berns puts the point: "according to liberalism - one renders unto Caesar whatever Caesar demands and to God whatever

131 Id. at 43 .

132 Id.

133 Id.

134 Id. at $44-45$. This passage is similar to Locke's treatment of the wider theme of constitutional limits on government in The Second Treatise of Government. There, he posited that "the body of the people" are the "proper umpire" in cases of controversy over the powers of the government. See J. Locke, The Second Treatise of Government $\$ 242$, in Two TrEatises of GoVERNMENT, supra note 118 , at 307, 476-77. But there is no lawful institution for vindication of the people's judgment. If the government does not honor the determination of the people on a contested point, "the appeal then lies nowhere but to heaven." Id. By this Locke meant revolution - a "state of war" between government and the people. The "supreme power" reverts to the people, who then have authority to "continue the legislative in themselves, or erect a new form, or under the old form place it in new hands, as they think good." Id. $\$ 243$, at I39. At a verbal level this "appeal to heaven" is the same remedy prescribed in $A$ Letter Concerning Toleration for a violation of religious freedom, but with an important difference. In the case of religious freedom, Locke did not claim that the "body of the people" - or anyone else on earth - can serve as judge between the believer and the government. Perhaps this is because duties to God (unlike other constitutional limits) are not defined or governed by the social contract. Perhaps it is also because, as Madison perceived, the "body of the people" are as likely to violate the conscience of a religious minority as is the government. For this reason, the "appeal to heaven" is unlikely to take the form of revolution unless the believers whose rights are violated constitute a majority, or at least a powerful minority. In the context of religious freedom, therefore, Locke pointed to the otherworldly consequences of the appeal to heaven: "God, I say, is the only judge in this case, who will retribute unto every one at the last day according to his deserts . . . ." J. LOCKE, A Letter Concerning Toleration, supra note Ir3, at 44. No political institution, nor even the remedy of revolution available under Locke's political theories, can be expected to vindicate these rights if the magistrate chooses not to do so. Locke's language thus subtly suggests that religious freedom is fundamentally more vulnerable than other rights. 
Caesar permits."135 When individual conscience conflicts with the governmental policy, the government will always prevail and the individual will always be forced to submit or suffer the punishment.

This understanding of religious toleration expressly precludes free exercise exemptions. The rights of religious exercise, according to Locke, are simply rights of nondiscrimination. "Whatsoever is lawful in the commonwealth, cannot be prohibited by the magistrate in the church. Whatsoever is permitted unto any of his subjects for their ordinary use, neither can nor ought to be forbidden by him to any sect of people for their religious uses." 136 Locke gave the example of a sect that wishes to sacrifice a calf. "I deny that that ought to be prohibited by a law," he said. ${ }^{137}$ Since individuals can lawfully kill a calf at home, and burn any part they see fit, they may do the same thing in a religious meeting. ${ }^{138}$ They are not entitled, however, to dispensations or exceptions:

[T]hose things that are prejudicial to the commonweal of a people in their ordinary use, and are therefore forbidden by laws, those things ought not to be permitted to churches in their sacred rites. Only the magistrate ought always to be very careful that he do not misuse his authority, to the oppression of any church, under pretence of public good. ${ }^{139}$

Accordingly, if the "interest of the commonwealth required all slaughter of beasts should be forborn for some while," the ritual slaughter of a calf for religious purposes may be forbidden as well. ${ }^{140}$

Locke's assertion of legislative supremacy and his opposition to special religious exemptions from generally applicable laws are consonant with arguments against free exercise exemptions. Unless there is reason to believe that the understanding of the free exercise clause held by the framers and ratifiers differed markedly from that of their intellectual forebear, Locke, Sherbert is historically unsupportable. ${ }^{141}$ As the next section demonstrates, however, the movement towards a more expansive notion of religious liberty would gain momentum in the wake of the American Revolution and shape the framing of both state and federal constitutions.

$135 \mathrm{~W}$. BERNS, supra note $\mathrm{I} 3$, at 44 .

$136 \mathrm{~J}$. LocKE, A Letter Concerning Toleration, supra note $\mathrm{II}_{3}$, at 34 .

137 Id.

138 See id.

139 Id. at $34-35$.

140 Id. at 34 .

141 The arguments against free exercise exemptions offered by Berns and Michael Malbin are based almost exclusively on Locke and his Enlightenment counterparts in America. See W. BERNS, supra note 13 ; M. MALBIN, supra note 17 . 


\section{Development of the Expansive Conception of Religious Freedom}

I. Disestablishment in the States. - The American Revolution immediately disrupted the relationship between religion and government in those states with an Anglican establishment. The Church of England was discredited during the Revolution by its connection to the Crown and the loyalist sympathies of most of its clergy. Accordingly, the Georgia Constitution of $\mathrm{I} 777$, the South Carolina Constitution of $I 778$, the North Carolina Constitution of 1776 , and the New York Constitution of 1777 (with reference to the four metropolitan counties that had an Anglican establishment) eliminated the special preferences and state support that had been given to the Church of England. South Carolina "established" the Protestant religion but gave it no governmental support, while Georgia authorized the imposition of a tax for the support of the taxpayer's "own profession." New York and North Carolina joined the ranks of states (Pennsylvania, New Jersey, Delaware, and Rhode Island) with no establishment. ${ }^{142}$

Virginia and Maryland were slower to adjust. Virginia adopted a free exercise provision in its Bill of Rights of $1776^{143}$ and exempted dissenters from payment of tithes to the Anglican Church; shortly thereafter, it temporarily suspended mandatory tithes for everyone. The Church was formally disestablished in 1785 , after a major popular and legislative battle in which James Madison played the leading role. ${ }^{144}$ The Maryland Declaration of Rights of 1776 authorized the legislature to "lay a general and equal tax, for the support of the Christian religion," 145 but during a protracted dispute in the Assembly in the I780's, supporters of an assessment were never able to prevail. ${ }^{146}$ Nonetheless, the Maryland legislature exercised continuing control over church affairs. So subservient was the established Church that in 1783 its clergy asked the legislature for permission to make changes in the prayer book. ${ }^{147}$ Accordingly, the Episcopal

142 See Ga. Const. of 1777 , art. LVI, reprinted in I Federal and STATE Constitutions, supra note 2 , at 377,383 ; N.Y. CONST of 1777 , art. XXXV, reprinted in 2 FEDERAL AND State Constitutions, supra note 2 , at 1328 , r338; N.C. Const. of 1776 , art. XXXIV, reprinted in 2 Federal AND STATE Constitutions, supra note 2, at 1409, 1413-14; S.C. CONST. of 1778 , art. XXXVIII, reprinted in 2 FEDERAL AND STATE CONSTITUTIONS, supra note 2, at $1620,1626-27$.

143 See Va. Bill of Rights of 1776 , reprinted in 2 FEderal and State Constitutions, supra note 2 , at 1908 .

144 See T. Buckley, Church and State in Revolutionary Virginia, 1776-1787, at 155-64 (1977).

145 Md. Declaration of Rights of 1776 , art. XXXIII, reprinted in I FEDERAL AND STATE Constitutions, supra note 2 , at $817,819$.

146 See T. CURRY, supra note 17 , at 154 .

147 See id. at $154-55$. 
Church of Maryland got the bitter of state meddling in church affairs without the sweet of regular state financial support.

The Congregational establishments of Connecticut, Massachusetts, New Hampshire, and Vermont were more firmly entrenched and emerged from the Revolution strengthened by their association with the patriot cause. In reference to the Massachusetts Congregationalists, John Adams observed that "[w]e might as soon expect a change in the solar system, as to expect that they would give up their establishment."148 And indeed, by I789 only these states maintained actual legal and financial support for the church. Outside of New England, only Maryland, South Carolina, and Georgia retained constitutional provisions permitting some form of establishment, and in none of these states did actual financial or other material support go into effect.

By I834, no state in the Union would have an established church, and the tradition of separation between church and state would seem an ingrained and vital part of our constitutional system. But as the delegates gathered at the Constitutional Convention in Philadelphia in 1787 and at the meeting of the First Congress in New York in I789, some form of establishment still held sway in most of New England, and the resolution of disestablishment controversies elsewhere could not be seen as assured.

2. The Evangelical Impetus Toward Religious Freedom. - The movement for freedom of religion in the I780's was part of a broad reaction against the dominant but uninspired religious cultures represented by the Congregationalists of New England and the Anglicans of the South. It is a mistake to read the religion clauses under the now prevalent assumption that "the governing intellectual climate of the late eighteenth century was that of deism (or natural law)."149 America was in the wake of a great religious revival. Historian Henry May has commented that the Enlightenment world view "excludes many, probably most, people who lived in America in the eighteenth and nineteenth centuries." 150 To determine the meaning of the religion clauses, it is necessary to see them through the eyes of their proponents, most of whom were members of the most fervent and evangelical denominations in the nation. ${ }^{151}$

One historian's portrait of Madison's neighbors, the Virginia Baptists, in the I760's may help recreate the actual intellectual - more

148 I W. McLoughLIN, supra note 5I, at 560 (quoting Isaac Backus' account of his confrontation with the Massachusetts delegation).

149 Marshall, supra note 17 , at 18 ; see also W. BERNS, supra note $\mathrm{I}_{3}$, at $\mathrm{I}-2, \mathrm{I}_{5}-32$ (same).

150 H. MAY, THE ENLIGHTENMENT IN AMERICA at xiv (1976).

151 This point was first brought to the attention of legal scholars by M. HowE, cited above in note 82 . 
precisely, spiritual - climate among the proponents of religious freedom:

Perhaps because they were at first largely lower class; perhaps because their worship sometimes caused their members to cry, bark like dogs, tremble, jerk, and fall to the ground; perhaps because they openly disdained the established religion and gentry mores; and perhaps because, as one Virginian charged, "they cannot meet a man on the road but they must ram a text of Scripture down his throat," the Baptists were reviled. They were seen as troublesome, and they were met with violence. ${ }^{152}$

It must have been particularly irksome to the gentry that the Baptists converted slaves in large numbers ${ }^{153}$ and included them "as 'brothers' and 'sisters' in their close communities."154 Even the Presbyterians, now pillars of mainstream Protestantism, were considered dangerously "enthusiastic" (meaning fanatical) by the authorities. Itinerant Presbyterian preachers in Virginia were said to "screw up the People to the greatest heights of religious Phrenzy, and then leave them in that wild state."155

The drive for religious freedom was part of this evangelistic movement. It is anachronistic to assume, based on modern patterns, that governmental aid to religion and suppression of heterodoxy were opposed by the more rationalistic and supported by the more intense religious believers of that era. The most intense religious sects opposed establishment on the ground that it injured religion and subjected it to the control of civil authorities. Guaranteed state support was thought to stifle religious enthusiasm and initiative. As Madison noted, the use of compulsory state taxes to support ministers would produce "pride and indolence in the Clergy; ignorance and servility in the laity."156 Moreover, establishment served as an instrument for state control over religion. This was particularly true in the states of the Anglican establishment, including Virginia, where the governor, legislature, and gentry exercised direct authority over the established church and the power of licensing over preachers of dissenting denominations. ${ }^{157}$ The establishment was localized and more democratic in

$152 \mathrm{~J}$. LEwIS, supra note 60 , at 49 . A similar, though more sympathetic, portrayal is found in $R$. IsAAC, cited above in note $6 \mathrm{I}$, at $\mathrm{I} 64-68$.

153 See R. ISAAC, supra note 6r, at $165-66$.

154 Id. at $17 \mathrm{I}-72$.

155 Id. at 550 ; see also D. Boorstin, The Americans: The Colonial Experience 13536 ( 1958 ) (providing an unflattering portrayal of the "Enthusiastick Preachers" of New Light Presbyterianism).

$156 \mathrm{~J}$. Madison, Memorial and Remonstrance, supra note 109, at 187 . This argument is elaborated by Adam Smith in A. Smith, The Wealth of Nations, bk. 5, ch. 1, pt. 3, art. 3, at 740-66 (E. Cannan ed. r937) (5th ed. 1789).

${ }^{157}$ See, e.g., D. Boorstin, supra note 155 , at $126-27,129$ (describing how, in the absence 
New England, but even there, the government set standards for licensing ministers and regulated ministerial tenure (hence ministerial independence) and itinerancy. ${ }^{158}$

State financial support was inevitably linked to control. The Baptists' declaration against the Virginia assessment proposal observed:

If, therefore, the State provide a Support for Preachers of the Gospel, and they receive it in Consideration of their Services, they must certainly when they Preach act as Officers of the State, and ought to be Accountable thereto for their Conduct, not only as Members of civil Society, but also as Preachers. The Consequence of this is, that those whom the State employs in its Service, it has a Right to regulate and dictate to; it may judge and determine who shall preach; when and where they shall preach; and what they must preach. ${ }^{159}$

The newer, more enthusiastic sects had the most to gain from breaking the monopoly of the old established church. This would allow new, often uneducated and itinerant preachers to conduct worship services and revival meetings and would make the financial support of a preacher dependent on the enthusiasm he generated among his adherents. The greatest support for disestablishment and free exercise therefore came from evangelical Protestant denominations, especially Baptists and Quakers, but also Presbyterians, Lutherans, and others. ${ }^{160}$ The decisive political event in the Virginia disestablishment struggle was the decision of the Presbyterians to

of a bishop in Virginia, the Anglican church was governed in temporal matters by the House of Burgesses and in other respects by the local gentry); S. CoBB, supra note 17 , at 97-98, 35153 (giving examples of restrictive licensing of ministers in Virginia and New York); id. at ro7 (recounting instances of investiture and defrocking of ministers by Virginia's governor); $i d$. at I26 (discussing governmental control over ministers under North Carolina law); id. at 393-94 (illustrating control by the proprietor over investiture in Maryland); T. CURRY, supra note I7, at 99 (describing Virginia's prohibition of itinerant preaching); R. IsAAc, supra note 6r, at I4854 (recounting the struggle by Presbyterians in Virginia for permission to hold religious meetings); R. Strickland, supra note 62, at 70, 83-87 (describing control by trustees over both the Church of England and Presbyterian ministries in Georgia).

158 See, e.g., S. COBB, supra note 17 , at $174,202-03$ (providing examples of the Massachusetts General Court's power to regulate doctrinal purity and the qualifications of preachers); $i d$. at 272-73 (recounting the adoption of laws against itinerant preaching in Connecticut); $T$. CURRY, supra note I7, at 99, II8 (discussing Connecticut laws against itinerant preaching); $i d$. at I7 I (discussing a Massachusetts law requiring ministers to possess degrees).

159 Declaration of the Virginia Association of Baptists (Dec. 25, 1776), in I PAPERS of JEFFERSON, supra note III, at 660, 66 (emphasis in original).

160 The small Jewish population of Philadelphia made its contribution to the struggle for free exercise with petitions against religious tests for office in Pennsylvania and at the federal level. See, e.g., Petition of the Philadelphia Synagogue to Council of Censors of Pennsylvania (Dec. 23, 1783), reprinted in 4 THE Founders' Constitution, supra note 72, at 635; Letter from Jonas Phillips to the President and Members of the Convention (Sept. 7, 1787), reprinted in 3 The Records of THE FEDERAL Convention of 1787 , at 78, 78-79 (M. Farrand ed. IgII and photo. reprint I966) [hereinafter FARRAND RECORDs]. 
desert the assessment cause and join the opposition. ${ }^{161}$ Madison's Memorial and Remonstrance Against Religious Assessments, with its mixed religious and secular arguments against the relatively liberal form of establishment proposed for Virginia in 1785 , garnered thousands of supportive signatures. Over twice as many Virginians, however, subscribed to petitions arguing against the assessment in frankly religious terms - stating, among other things, that the bill violated "the Spirit of the Gospel."162

Religious rationalists, who are often credited with the leading intellectual role in the movement for religious freedom, were far more likely than the enthusiastic believers to side with the established church (with notable exceptions such as Jefferson). ${ }^{163}$ Ironically, it was the Unitarian wing of the Standing Order, Jefferson's favored theological position, that led the fight against disestablishment in Massachusetts, ${ }^{164}$ while the "enthusiastic" Baptists sought to cast down all vestiges of the establishment. The established religions - the Congregational churches of New England and the Anglican churches of the South - tended to be far more intellectual, uninspired, and agreeable to rationalist sensibilities, in contrast to the disturbing enthusiasm of the upstart denominations.

The religious supporters of disestablishment and free exercise in the various states also supported adoption of constitutional protections at the federal level, for essentially the same reasons. They were joined in the latter cause by a heterogeneous coalition called the Antifederalists, who used the absence of a bill of rights as an argument against ratification of the Constitution. This was little more than a marriage

${ }^{161}$ As the established church of Scotland, the Presbyterians had no doctrinal tradition of opposition to establishment. Their principal concern with the proposed assessment bill was that its provision for support of the clergy would undermine the control of the elders over the minister and the church. See T. BuCKLEY, supra note 144, at 92-96, 137-139. Shortly after the assessment controversy, the Presbyterians in the United States formally amended their Confession of Faith to renounce their prior support for establishment. See Presbyterian Church (U.S.A.), "God Alone is LORD of the Conscience": Policy STATEMENT and Recommendations Regarding Religious Liberty 7, 69-70 (I988) [hereinafter Presbyterian Policy Statement].

${ }^{162}$ See T. BUCKLEY, supra note $\mathrm{r} 44$, at $\mathrm{I} 48-50$; T. CURRY, supra note $\mathrm{I} 7$, at $\mathrm{I} 43-44$.

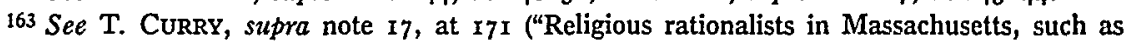
Samuel West, Charles Chauncey, and other ministers who benefited from the state-supported religious system, remained its devoted upholders and insisted on its fairness."); see also D. Boorstin, supra note $\mathrm{r}_{55}$, at $\mathrm{r}^{2-39}$ (describing the undogmatic character of the Anglican Church of Virginia); R. ISAAC, supra note 6r, at 120-2I (same); id. at 153 (reporting a sermon by an Anglican minister to the Virginia House of Burgesses that advocated "rational" religion and denounced the New Light evangelical movement); R. STrickLAND, supra note 62, at 65 (describing a "typical eighteenth century Church of England man" in Georgia as "decrying Calvinism, 'enthusiasm' and the doctrines of regeneration").

${ }_{164}$ See McLoughlin, Editor's Introduction to I. BACKUS, Government and Liberty Described, in Church, STATE, ANd Calvinism, supra note 116 , at $345,346$. 
of political convenience, for the advocates of religious freedom had little in common with the political principles of most Antifederalists. The Baptists of Virginia must have found it awkward to join forces with Patrick Henry, Virginia's leading Antifederalist, who had so recently championed the movement for religious assessments. Yet in the ratification convention in Virginia it was Henry who took up the issue of religious freedom and the absence of a Bill of Rights, ${ }^{165}$ while Madison, the erstwhile supporter of religious freedom, urged ratification of the Constitution without amendment. ${ }^{166}$

The political theory of the advocates of free exercise sharply conflicted with the "republican" ideology that prevailed among most Antifederalists (as well as many Federalists). ${ }^{167}$ The central preoccupation of republican political theory was the necessity of public "virtue." In its religious manifestation, this meant that government should support and encourage religion in order to promote public morality. ${ }^{168}$ The Massachusetts Constitution of 1780 , for example, justified its ministerial taxes on the ground that "the happiness of a people and the good order and preservation of civil government essentially depend on piety, religion, and morality."169 The Virginia assessment proposal was defended on the same ground. A petition by citizens of Isle of Wight County, for example, stated: "being thoroughly convinced that the prosperity and happiness of this country essentially depends on the progress of religion, they . . . [pray] that an act may pass to compel every one to contribute something, in proportion to his property, to the support of religion."170 The most famous statement of this sort was Washington's farewell address, in which he stated that "[o]f all the dispositions and habits which lead to political prosperity, religion and morality are indispensable supports. . . . And let us with caution indulge the supposition that morality can be maintained without religion."171

165 See 3 The Debates in the Several State Conventions on the Adoption of the FEDERAL CONSTITUTION 317-18 (J. Elliott 2d ed. I836) [hereinafter Elliot's DEBATES] (June I2, I788).

166 See id. at 330.

${ }^{167}$ For recent analyses of republican ideology, see M. Tushnet, RED, White, AND BluE: A Critical Analysis of Constitutional Law 4-14 (1988); Michelman, The Supreme Court, I985 Term - Foreword: Traces of Self Government, I00 HARV. L. REv. 4 (1986); and Sunstein, Beyond the Republican Revival, 97 YALE L. J. I539 (1988).

168 See G. Wood, The Creation of The AMERICAN Republic I 776-1787, at 426-29 (I969).

169 Mass. Declaration of Rights of 1780 , art. III, in I FEDERAL AND STATE CONSTITUTIONS, supra note 2 , at 957 .

170 Petition for General Assessment (Nov. 4, I784), reprinted in C. JAMES, DocumentaRy History of the Struggle for Religious Liberty IN VirginIA I25, I25 (Ig0o and photo. reprint 1971 ).

171 Washington, Farewell Address (Sept. I7, 1796), reprinted in I DocUMENTS OF AMERICAN HISTORY I69, I73 (H. Commager 9th ed. 1973). 
These arguments ran directly contrary to the position of the evangelical advocates of the religion clauses. To be sure, these advocates did not deny that religion is necessary to civil society. Isaac Backus, for example, affirmed that "religion is as necessary for the well-being of human society as salt is to preserve from putrefaction or as light is to direct our way and to guard against enemies, confusion, and misery."172 But they did deny that governmental support is necessary, or even useful, to religion. ${ }^{173}$ According to Elder John Leland, leader of the Virginia Baptists, "[i]t is error alone, that stands in need of government to support it; truth can and will do better without . . . it."174 Moreover, the evangelicals found this very mode of argument objectionable, because it implied that religion was to be used as an instrument of statecraft, thus implicitly subordinating religion to the goal of "political prosperity." As Backus caustically observed of the Massachusetts establishment, "a little while ago" the establishment was "for religion," but now it is said to be "for the good of civil society." 175

The paradox of the religious freedom debates of the late eighteenth century is that one side employed essentially secular arguments based on the needs of civil society for the support of religion, while the other side employed essentially religious arguments based on the primacy of duties to God over duties to the state in support of disestablishment and free exercise. It was Baptist preacher John Leland who first stated that "[t]he notion of a Christian commonwealth, should be exploded forever." 176

Although the secular strain of republicanism was less an object of the evangelicals' polemics, it was no less inconsistent with their understanding of the proper role of the state. Civic republicanism sought to inculcate public virtue through various devices, including sumptuary laws, education, and participatory politics. To the evangelical advocates of religious freedom, this too was a vain extension of the governmental sphere; virtue is either impossible or incoherent when divorced from duty to God. Their position places the state in the precarious posture of depending upon autonomous institutions to preserve the moral conditions necessary to the survival of republican government.

Thus, the evangelical position ultimately coalesced with the secular liberal position, as against the dying tradition of civic republicanism.

172 I. Backus, Policy, as Well as Honesty, Forbids the Use of Secular Force in Religious

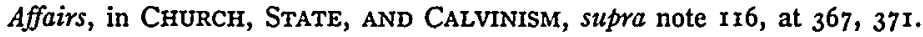

173 See supra pp. 1438-40.

$174 \mathrm{~J}$. LeLANd, The Virginia Chronicle, in The Writings of ThE LATE ELDER JoHN LELAND 9I, Ir8 (L. Greene ed. I845) [hereinafter LELAND Writings].

175 I. Backus, An Appeal to the Public for Religious Liberty, in ChURCH, STATE, AND CALvinism, supra note 116 , at 303,324 (emphasis in original).

$176 \mathrm{~J}$. LELAND, supra note $\mathrm{I} 74$, at 107. 
This explains why the more fervent evangelicals, including the Baptists, tended to become Jeffersonians, notwithstanding the deism of Jefferson and the piety of his opponents. Religion, the evangelicals believed, is vital to civic harmony. But voluntary religious societies - not the state - are the best and only legitimate institutions for the transmission of religious faith and, with it, virtue. The only support that churches can legitimately expect from the government, apart from equal participation in the benefits of civil society, is protection and noninterference. ${ }^{177}$

3. Advances Beyond Locke in the Popular Understanding of Religious Freedom. - The same evangelical forces converged in support of protections for religious liberty through free exercise provisions in state constitutions. It is no accident that Locke's vocabulary ("toleration of religion") was rejected in favor of more sweeping terms not just the "exercise," but the "free exercise" of religion, or "full and equal rights of conscience." When George Mason proposed the term "toleration" for the religious liberty clause of the Virginia Bill of Rights, ${ }^{178}$ Madison objected on the ground that the word "toleration" implies an act of legislative grace, which in Locke's understanding it was. Madison proposed, and the Virginia assembly adopted, the broader phrase: "the full and free exercise of [religion]."179

Madison was far from alone in his rejection of the concept of "toleration." Tench Coxe, a prominent essayist, stated that "[m]ere toleration is a doctrine exploded by our general constitution." $180 \mathrm{He}$ said that the Americans had "substituted an unqualified admission and assertion, that their own modes of worship and of faith equally belong to all the worshippers of God, of whatever church, sect, or denomination."181 George Washington, in his famous address to the Hebrew

177 See J. LELAND, The Rights of Conscience Inalienable, in LELAND WRITINGS, supra note I74, at I79, I84. Leland wrote:

Let every man speak freely without fear, maintain the principles that he believes, worship according to his own faith, either one God, three Gods, no God, or twenty Gods; and let government protect him in so doing, i.e., see that he meets with no personal abuse, or loss of property, for his religious opinions.

Id. The Presbyterian Church formally adopted a similar position at its first General Assembly in 1788: "We do not even wish to see any religious constitution aided by the civil power, further than may be necessary for protection and security, at the same time be equal and common to all others." Presbyterian Policy Statement, supra note $16 \mathrm{~T}$, at 7 (quoting the Presbyterian Principles of Church Order).

178 See Hunt, James Madison and Religious Liberty, I ANN. REp. AM. HIST. A. 163, I66 (Igor). Mason's proposal read in relevant part: "'that all men should enjoy the fullest toleration in the exercise of religion, according to the dictates of conscience, unpunished and unrestrained by the magistrate, unless under color of religion any man disturb the peace, the happiness, or safety of society."' Id.

179 Id.

180 Kurland, supra note $\mathrm{I} 7$, at 857 (quoting T. COXE, A VIEW of THE UNITEd STATES of AMERICA 103-04 (Philadelphia 1794)).

181 Id. 
Congregation of Newport, Rhode Island, stated: "It is now no more that toleration is spoken of, as if it was by the indulgence of one class of people, that another enjoyed the exercise of their inherent natural rights." 182 More pungently, Thomas Paine commented: "Toleration is not the opposite of intolerance, but is the counterfeit of it. Both are despotisms. The one assumes to itself the right of withholding liberty of conscience, and the other of granting it."183 The United States, several millions of dissenters and a century of pluralism ahead of Locke's England, had advanced beyond mere toleration of religion.

There are two primary reasons to believe that the popular conception of free exercise on this side of the Atlantic was more expansive than Locke's doctrine of religious toleration: the advent of judicial review, and a difference in conception of the nature and role of religion.

(a) Judicial Review. - One reason that Locke's doctrines may have seemed so limited from an American perspective is that he did not envision an authority within the law that was capable of limiting the sovereign power of the "magistrate" (by which he meant the government, the King, and Parliament). "[T]here is no judge upon earth between the supreme magistrate and the people."184 While Locke recognized the moral imperative to obey God instead of civil rulers, ${ }^{185}$ his conception of political institutions did not include a mediator who could transform this moral, prepolitical right into positive law. In the absence of such a mediator, individual conscience could be compelled to yield to government in the event of a conflict. For Locke, the field left to untrammeled conscience could only extend to that in which the civil magistrate had no particular interest principally, to things pertaining to the world to come. Religious liberty could only be defined negatively; any broader definition would be pointless, since the magistrate would be judge of his own powers.

Locke's key assumption of legislative supremacy no longer holds under a written constitution with judicial review. The revolutionary American contribution to political theory was that the people themselves are sovereign and therefore possess inherent power to limit the power of the magistrate, through a written constitution enforced by judges independent of the legislature and executive. As Madison would predict during deliberation over the Bill of Rights:

If [the provisions of the Bill of Rights] are incorporated into the constitution, independent tribunals of justice will consider themselves

182 3I G. Washington, The Writings of George Washington 93 n.65 (J. Fitzpatrick ed. I939).

183 T. Paine, The Rights of Man, pt. $\mathrm{I}$, in I The Complete Writings of Thomas Paine 243, 291 (P. Foner ed. 1945) (emphasis in original).

$184 \mathrm{~J}$. LOCKE, A Letter Concerning Toleration, supra note 113, at 44.

185 See id. at $43-45$. 
in a peculiar manner the guardians of those rights; they will be an impenetrable bulwark against every assumption of power in the legislative or executive; they will be naturally led to resist every encroachment upon rights expressly stipulated for in the constitution by the declaration of rights. ${ }^{186}$

Once the courts are vested with the power to determine the proper boundary between individual conscience and the magistrate's authority, based on the words of a written charter derived from the people, fuller protection for conscience becomes conceivable. An independent judiciary could define religious liberty affirmatively, in terms of what religious liberty requires, and not merely what the legislature concedes. The modern "judicial restraint" position, that legislatures are entitled to make free exercise exemptions but courts are not, is a relic of Lockean legislative supremacy. Once the people empowered the courts to enforce the boundary between individual rights and the magistrate's power, they entrusted the courts with a responsibility that prior to 1789 had been exercised only by the legislature.

(b) The Nature and Role of Religion. - Those most engaged in the struggle for religious freedom guarantees in the United States also departed from Locke's understanding of the role of religion and the utility of religious liberty. While they put Locke's arguments to good effect in legitimating their position, the free exercise apologists used Locke opportunistically, ignoring implications of his argument that were inconvenient to their case. To Locke, religious divisions and discord presented a political problem; the solution was to keep the peace by making religion irrelevant to the things of this world other than a reasonable, uncontroversial advocacy of good morals, which would be fully consistent with the public good, publicly defined.

This was not the religious enthusiasts' idea of religion and not their idea of religious liberty. To them, the church-state problem was principally a religious problem: the state too frequently used its power to prevent the practice and spread of the gospel. The Baptists languishing in the Culpepper jail and the Presbyterians fighting legislative interference with their form of church governance were not fearful of religion. They were fearful of government. To the evangelical spirit of the minority Protestant sects in America, Locke's conception of the separation between the secular and the religious would have seemed absurd. Does not the will of God govern all of life? Is $\mathrm{He}$ not sovereign over all? To the preachers who only recently had been among the leading advocates of revolution against the King, Locke's

186 I ANNALS OF CoNG. 457 (J. Gales ed. 1834) (June 8, 1789). The evidence is overwhelming that the framers and ratifiers understood and intended the courts to engage in constitutional judicial review. For a brief summary, see D. CURRIE, The Constitution in the Supreme CoURT: The FirST HUNDREd YeARS 1789-1888, at 69-70 (1985). 
claim that they should be "forbidden meddling with making or executing laws in their preaching"187 must have seemed quaint, as well as presumptuous. If Locke and Jefferson wished to promote a peaceable, rational religion that minds its own business, is tolerant of others, and does not meddle in affairs of state, ${ }^{188}$ their aspirations were diametrically opposed to those whose political efforts produced the first amendment.

These differing conceptions of the purposes of religious freedom have clear implications for the question of free exercise exemptions. From the religious perspective, the scope of free exercise cannot be defined, in the first instance, by asking what matters the public is rightly concerned about. Religion involves itself in many matters of importance to the public. Free exercise must be defined, in the first instance, by what matters God is concerned about, according to the conscientious belief of the individual.

In this respect, Madison's argument in the Memorial and Remonstrance echoed evangelical convictions about the roles of religion and civil government. His position that duty to God precedes the claims of civil society ${ }^{189}$ strongly resembles the teachings of John Witherspoon, the nation's leading Presbyterian clergyman and President of the College of New Jersey (Princeton) while Madison was a student. In an address that Madison might have heard, Witherspoon observed:
Another reason why the servants of God are represented as trouble- some is, because they will not, and dare not comply with the sinful commandments of men. In matters merely civil, good men are the most regular citizens and the most obedient subjects. But, as they have a Master in heaven, no earthly power can constrain them to deny his name or desert his cause. ${ }^{190}$

The demands of civil society must be judged against the demands of God. That is why the "servants of God" seem "troublesome" and why a society that determines to respect the claims of conscience must recognize exemptions from its laws.

$187 \mathrm{~J}$. LOCKE, EsSays on the LAW OF NATURE 275 (W. von Leyden ed. 1954) (ca. 1660).

188 Compare Jefferson's praise for the Virginia Methodists with his criticism of the Presbyterian clergy: "The Methodists are republican mostly, satisfied with their governmt. [,] medling with nothing but the concerns of their own calling and opposing nothing"; the Presbyterian clergy "are violent, ambitious of power, and intolerant in politics as in religion and want nothing but license from the laws to kindle again the fires of their leader John Knox, and to give us a 2d blast from his trumpet." Letter from Thomas Jefferson to Dr. Thomas Cooper (March 13, I820), in The Life and Selected Writings of Thomas JefFerson 697, 697 (A. Koch \& W. Peden eds. I944) [hereinafter Selected Writings of Jefferson].

${ }^{189}$ See infra text accompanying notes 229-230.

$190 \mathrm{~J}$. Witherspoon, The Charge of Sedition and Faction Against Good Men, Especially Faithful Ministers, Considered and Accounted for, in 2 THE WORKS OF THE REv. JOHN Witherspoon 4I5, 427 (Philadelphia 1802). 
While the argument for exemptions tended to be oblique and by implication, opponents of free exercise automatically assumed that liberty of conscience must entail exemptions, and thus claimed that free exercise was tantamount to anarchy. Proponents of exemptions could have responded by denying any claim to exemptions and confining their opposition to discriminatory treatment. But this was not their approach. Proponents did attempt to minimize the practical consequences of the exemptions position by stoutly declaring their fealty to almost all of the laws. But they cleverly used ambiguous language to leave open the theoretical possibility that conscience would prevail over wrongful legislation.

The question of exemptions arose for the first time in the disputation between John Cotton and Roger Williams in the I640's and I650's. ${ }^{191}$ Williams argued that the government has no authority to enforce the so-called "First Table" (the first four commandments, which deal with religious worship). ${ }^{192}$ Cotton responded that this undermined the government's authority to enforce the "Second Table" (murder, theft, perjury, etc.), as well. ${ }^{193}$ As Thomas Curry, author of the of the leading history of church-state conflicts in preconstitutional America, observes:

This rebuttal to Williams derived its strength from its solid foundation in a very real problem, which Williams was unable to tackle and which still has not been solved: how to distinguish between those areas that belong only to religion or conscience and those that belong to the law. In other words, to what extent does a claim to the free exercise of religion exempt one from the laws of the land? ${ }^{194}$

If conscience must be respected, and if conscience can be defined in no way other than by the individual believer, then doesn't liberty of conscience give believers a license to violate laws vital to social order?

Williams never provided a direct response to this question. William Penn did. In The Great Case of Liberty of Conscience, Penn posed and answered a number of "objections" made by opponents of religious freedom. To objection number three, "[b]ut at this Rate ye may pretend to Cut our Throats, and do all Manner of Savage Acts, "195 Penn responded:

Though the Objection be frequent, yet it is as foully ridiculous[.] We are pleading only for such a Liberty of Conscience, as preserves the Nation in Peace, Trade, and Commerce; and would not exempt any

191 The exchange is summarized in T. CuRRY, cited above in note I7, at I8.

192 See id.

193 See id.

194 Id.

195 W. PENN, supra note I07, at 457. 
Man, or Party of Men, from not keeping those excellent Laws, that tend to Sober, Just, and Industrious Living. ${ }^{196}$

This endorsement of certain "excellent laws" falls conspicuously short of a denial of exemption from any laws. Penn went on to deny that the Quakers had violated any laws, properly so called, even though "[i]f the enacting any Thing can make it lawful," it was true that the Quakers had violated the "law" against unlawful assemblies. 197 His position was that "law" in the true sense was confined to limited purposes, which could not conflict with Quaker practices. He argued that "the Words Lareful or Unlaveful" must "bear their Signification from the Nature of the Things they stand for" rather than from mere enactment into statutes. 198

A century later, John Leland, the leader of the Baptists in Virginia during the assessment controversy and the enactment of the first amendment, addressed the same question. Like Penn, he condemned in the strongest language the notion that liberty of conscience would justify crimes such as murder or tax evasion:

Should a man refuse to pay his tribute for the support of government, or any wise disturb the peace and good order of the civil police, he should be punished according to his crime, let his religion be what it will; but when a man is a peacable subject of state, he should be protected in worshipping the Deity according to the dictates of his own conscience. ${ }^{199}$

But also like Penn, Leland made clear that this did not mean that believers could be required to obey all laws. "It is often the case," he wrote, "that laws are made which prevent the liberty of conscience; and because men cannot stretch their consciences like a nose of wax, these non-conformists are punished as vagrants that disturb the peace."200 Unfortunately, Leland supplied no clear basis for distinguishing between the cases. "Let any man read the laws," he said, "and see who were the aggressors." 201 Instead, he seems to have assumed that the distinction would be readily apparent. When a believer's "practice is opposed to good law, he is to be punished,"202 but when the law has invaded the province of conscience, punishment would be an aggression.

$196 I d$.

197 Id. at 458 .

198 Id.

${ }^{199} \mathrm{~J}$. LELAND, The Yankee Spy, in LELAND Writings, supra note 174 , at $213,228$.

$200 \mathrm{Id}$.

201 Id.

202 Id.; see also I. BAcKUS, supra note $\mathrm{I75}$, at $3 \mathrm{I} 7$ ("We view it to be our incumbent duty to render unto Caesar the things that are his but also that it is of as much importance not to render unto him anything that belongs only to God, who is to be obeyed rather than any man."). 
Locke's position of no exemptions would have been an easier one to maintain, especially for the Baptists, whose religious practices did not conflict with any generally applicable secular laws. But the Baptists and other proponents of religious freedom in America did not adopt Locke's position, presumably because they insisted on defining liberty of conscience as adherence to the demands of God. This, then, is the key difference between the Lockean view and the popular American view: the former takes the perspective of government and the latter the perspective of the believer. It remains to be seen which of these perspectives dominated the legal arrangements for religious liberty in the years leading up to 1789 .

4. The Views of the Framers. - The growing popular support for broad religious freedom within the newly formed American states helped to shape the views of the framers of the Constitution and the free exercise clause. Of particular interest are the contrasting positions of Jefferson and Madison regarding the religion issue, not only because they played the key roles in formulating the free exercise clauses of Virginia and the federal Constitution, but also because their differences illuminate the American evolution away from the narrower conception of religious liberty championed by Locke.

Like Locke, Jefferson favored a mild, tolerant, and rationalistic brand of religion. 203 Professor Sanford Kessler points out that "Jefferson's debt to Locke in theological matters was so great that in some instances he accepted Locke's interpretation of the gospels over what he believed to be the doctrines of Jesus himself."204 As Locke advocated a watered-down and de-politicized Christianity in his Reasonableness of Christianity, so Jefferson took the more radical step of composing his own version of the gospels, excluding everything at variance with his understanding of science and natural morality. ${ }^{205}$ Jefferson far surpassed Locke in his hostility to orthodox Christianity. Jefferson called Athanasius and Calvin - the pillars of Catholic and Reformed theology - "impious dogmatists" and "mere usurpers of the Christian name, teaching a counter-religion made up of the deliria of crazy imaginations." 206 He denied the divinity of Christ and the

${ }^{203}$ See Kessler, Jefferson's Rational Religion, in The Constitutional Polity: Essays on the Founding Principles of American Politics 58 (S. Pearson ed. I983); Kessler, supra note I13; Little, Thomas Jefferson's Religious Views and Their Infiuence on the Supreme Court's Interpretation of the First Amendment, 26 CATH. U.L. REV. 57, 58-64 (1976).

${ }^{204}$ Kessler, supra note II3, at 247-48 (footnotes omitted).

205 See T. Jefferson, The Life and Morals of Jesus of Nazareth (Philadelphia I804 and photo. reprint I904). For example, Jefferson deleted from his narrative all of the miracles of Jesus reported in the New Testament.

206 Letter from Thomas Jefferson to Dr. Benjamin Waterhouse (June 26, 1822), in $\mathrm{x} 2 \mathrm{THE}$ Works OF ThOMAS JEFFERSON 24I, 242 (P. Ford ed. IgO5) [hereinafter WORKS OF JEFFERSON] (emphasis in original); see also Letter from Thomas Jefferson to John Adams (April II, I823), in SElected Writings of JefFerson, supra note 188, at 705-06 (calling Calvin "an atheist, ... or rather his religion was daemonism"). 
authority of scripture, ${ }^{207}$ condemned the Protestant doctrine that forgiveness of sins is achieved through repentance as opposed to good works, ${ }^{208}$ and ridiculed Presbyterians, among others, for "fanaticism" in matters of religion. ${ }^{209} \mathrm{He}$ was equally contemptuous of Judaism, whose theology he called "degrading and injurious" and whose ethics he called "repulsive."210

Jefferson advocated religious freedom, in large part, as a means of combatting religious enthusiasm and advancing the day when all would become adherents of Unitarianism, his idea of a rational and sensible religion:

I rejoice that in this blessed country of free inquiry and belief, which has surrendered its creed and conscience to neither kings nor priests, the genuine doctrine of one only God is reviving, and I trust that there is not a young man now living in the United States who will not die an Unitarian. ${ }^{211}$

This Lockean-Jeffersonian preference for rational over traditional religion continues to characterize one strain, perhaps the dominant strain, of American liberalism. ${ }^{212}$

In many respects, Jefferson advocated a fuller freedom of religion than Locke. Whereas Locke favored a single established church, Jefferson opposed any form of state-established church, even the broad multiple establishment proposed for Virginia. Unlike Locke, Jefferson

207 See Letter from Thomas Jefferson to Peter Carr (Aug. Io, 1787), in SELECTEd Writings OF JEFFERSON, supra note 188 , at 429, 43I-33; Letter from Thomas Jefferson to William Short (Aug. 4, I820), in 15 THE Writings of ThOMAS JEFFERSON 257, 261-62 (A. Lipscomb ed. I903) [hereinafter WRITINGS OF JEFFERSON].

208 See Letter from Thomas Jefferson to William Short (April 13, 1820), in I5 Writings of JEFFERSON, supra note 207 , at $243,244$.

${ }^{209}$ Letter from Thomas Jefferson to Dr. Thomas Cooper (Nov. 2, 1822), in Thomas JEFFERSON: WRITINGS 1463 , 1464 (M. Peterson ed. 1984). Jefferson once wrote to John Adams: "If, by religion, we are to understand Sectarian dogmas, in which no two of them agree, then your exclamation on that hypothesis is just, "that this would be the best of all possible worlds, if there were no religion in it." Letter from Thomas Jefferson to John Adams (May 5, 1817), in 2 The AdAMS-JefFerson Letters 512, 512 (L. Cappon ed. 1959) (emphasis in original).

$210 \mathrm{See}$ Letter from Thomas Jefferson to Dr. Benjamin Rush (April 21, 1803), in SELEcted Writings of JEFFERSON, stipra note 188, at 566, 569 (enclosing Jefferson's Syllabus of an Estimate of the Merit of the Doctrines of Jesus, Compared with Those of Others); see also Letter from Thomas Jefferson to John Adams (Oct. 12, 1813), in 2 THE ADAMS-JEFFERsoN LETTERS, supra note 209 , at $383,383-84$ (commenting on the "wretched depravity of sentiment and manners" which prevailed among the Jews, and which Jesus undertook to reform).

211 Letter from Thomas Jefferson to Dr. Benjamin Waterhouse (June 26, 1822), supra note 206 , at 243 (emphasis in original). To similar effect, see Letter from Thomas Jefferson to James Smith (Dec. 8, 1822), in SElected WrITINGS OF JEFFERSON, cited above in note 188, at 703; cf. Letter from Thomas Jefferson to John Adams (April 11, 1823), in 2 THE ADAMS-JEFFERSON LETTERS, supra note 209, at 59I, 593-94 (rejecting the doctrine of a Holy Spirit separate from God).

212 See, e.g., J. Dewey, A Common FaITh (1934). 
would extend toleration to atheists and Catholics, though he appeared to agree that toleration should be denied those who would not tolerate others. ${ }^{213}$ Unlike Locke, Jefferson would deny all power to the government to provide financial support for religious teaching, arguing that "to compel a man to furnish contributions of money for the propagation of opinions which he disbelieves and abhors, is sinful and tyrannical."214 Finally, Jefferson departed from Locke's views by denying the authority of governmental officials to promote or encourage religion, even through persuasion. ${ }^{215}$

Jefferson's understanding of the scope and rationale of free exercise rights, however, was more limited even than Locke's. Like Locke, he based his advocacy of freedom of religion on the judgment that religion, properly confined, can do no harm: "The legitimate powers of government extend to such acts only as are injurious to others. But it does me no injury for my neighbour to say there are twenty gods, or no god. It neither picks my pocket nor breaks my leg."216 On this rationale, Jefferson espoused a strict distinction between belief, which should be protected from governmental control, and conduct, which should not. As he wrote in his famous "wall of separation" letter to the Danbury Baptist Association, "the legislative powers of government reach actions only, and not opinions . . . . [M] an . . . has no natural right in opposition to his social duties." 217 It was in reliance on Jefferson that the Supreme Court later held that there can be no free exercise right to exemption from a generally applicable law when such laws are directed at actions and not opinions. ${ }^{218}$

Jefferson's advocacy of a belief-action distinction placed him at least a century behind the argument for full freedom of religious exercise in America. William Penn wrote in I670 that "by Liberty of Conscience, we understand not only a meer Liberty of the Mind, in believing or disbelieving . . . but the exercise of ourselves in a visible way of worship."219 Historian Thomas Curry recounts the I65 I flogging of Obediah Holmes, a Baptist, for holding a religious meeting in Lynn, Massachusetts: "To the familiar argument that he was sentenced not for conscience but for practice, Clark replied that there could be

213 See T. JEFFERSON, supra note III, at 550 n.2.

214 Jefferson, A Bill for Establishing Religious Freedom (June 12, 1779), reprinted in 5 THE FOUNDERS' CoNSTITUTION, supra note 72 , at 77,77 .

215 See Letter from Thomas Jefferson to the Rev. Samuel Miller (Jan. 23, I808), in II WORKS OF JEFFERSON, supra note 206, at 7 (explaining his refusal to issue a presidential proclamation of a day of fasting and prayer).

216 T. Jefferson, Notes on the State of Virginia 159 (W. Peden ed. I955) (Ist ed. 1787).

217 Letter from Thomas Jefferson to a Committee of the Danbury Baptist Association (Jan.

1,1820 ), in 16 WRITINGS OF JEFFERSON, supra note 207, at 28I, 28I-82.

${ }^{21 \times}$ See Reynolds v. United States, 98 U.S. 145,164 (1878).

2"W. PENN, supra note 107, at 447 (emphasis in original). 
no such thing as freedom of conscience without freedom to act."220 It is unlikely that many Americans would have disputed that position by I 789 . St. George Tucker, no radical, wrote in 1803 that "[l]iberty of conscience in matters of religion consists in the absolute and unrestrained exercise of our religious opinions, and duties, in that mode which our own reason and conviction dictate."221 Thus, while Jefferson was one of the most advanced advocates of disestablishment, his position on free exercise was extraordinarily restrictive for his day. ${ }^{222}$

Although often linked with Jefferson's "Enlightenment-deist-rationalist" stance toward religious freedom, ${ }^{223}$ Madison's views on the religion-state question should be distinguished from those of his fellow Virginian, and hence from Locke. ${ }^{224}$ To begin with, Madison possessed a far more sympathetic attitude toward religion than did Jefferson. ${ }^{225}$ While Madison's religious convictions as an adult are unknown, as a young man he attended a Presbyterian college in New Jersey (Princeton) instead of pursuing the more natural course of study at the Anglican college, William and Mary, in his own state. Madison's correspondence with his close friend, William Bradford, suggests that the more evangelical Presbyterian teachings took hold, at least for a time; he urged Bradford to become a "fervent Advocate[ in the cause of Christ."226 None of Madison's writings displayed the disdain Jefferson expressed for the more intense manifestations of religious spirit. Indeed, the sight of "5 or 6 well meaning men" - Baptist preachers imprisoned in Culpepper, Virginia "for publishing their religious Sentiments which in the main are very orthodox" - sparked his concern for religious freedom. The usually soft-spoken Madison described such persecution as a "diabolical Hell conceived principle,"

$220 \mathrm{~T}$. CURRY, supra note $\mathrm{I} 7$, at 15 .

221 ST. George Tucker, I Blackstone's Commentaries, reprinted in 5 The Founders' Constitution, supra note 72 , at 96,97 (emphasis added).

222 For this reason, Michael Malbin's argument against free exercise exemptions must be rejected. After noting that Jefferson opposed free exercise exemptions, Malbin contends that "whatever protection the free exercise clause might have meant to give to religion, it was not likely to have been greater than the protection Jefferson thought religion should be given." $M$. MALBIN, supra note 17 , at 36 .

${ }^{223}$ See D. RichaRdS, supra note 54, at III-2I, I47-48; Pepper, supra note 18 , at 314 . The Supreme Court has repeatedly linked Jefferson and Madison as if their thought were identical. See, e.g., School Dist. v. Schempp, 374 U.S. 203, 214 (1963); McGowan v. Maryland, 366 U.S. 420, 465 (I96I) (Frankfurter, J. concurring); Everson v. Board of Educ., 330 U.S. I, 40 (1947) (Rutledge, J. dissenting); Reynolds v. United States, 98 U.S. 145, 163-64 (1878).

224 See Pepper, supra note 18, at 320-21. For a discussion of differences between Madison and Jefferson in other areas, see A. KoCH, JefFERson and Madison: the Great CollaboRATION 43-46 (I950).

${ }^{225}$ See Ketcham, James Madison and Religion: A New Hypothesis, in JaMES MADISON oN RELigious Liberty i 75 (R. Alley ed. I985).

226. Letter from James Madison to William Bradford (Sept. 25, 1773), in I The Papers of Ja.ues Madison 95, 96 (R. Rutland \& C. Hobson eds. I977) [hereinafter Madison Papers]. 
and stated that it "vexes me the most of any thing whatsoever."227 He recounted that he had "squabbled and scolded abused and ridiculed so long about it, [to so lit]tle purpose that I am without common patience."228 This formative experience exemplifies the marked difference between Madison and Jefferson in their attitudes towards religious liberty. In all Jefferson's writings about liberty of conscience, he never once showed concern for those who wish to practice an active faith; to Jefferson, unlike Madison, liberty of conscience meant largely freedom from sectarian religion, rather than freedom to practice religion in whatever form one chooses.

Consistent with this more affirmative stance toward religion, Madison advocated a jurisdictional division between religion and government based on the demands of religion rather than solely on the interests of society. In his Memorial and Remonstrance, he wrote:

The Religion then of every man must be left to the conviction and conscience of every man; and it is the right of every man to exercise it as these may dictate. . . . It is the duty of every man to render to the Creator such homage, and such only, as he believes to be acceptable to him. ${ }^{229}$

Moreover, Madison claimed that this duty to the Creator is "precedent both in order of time and degree of obligation, to the claims of Civil Society," and "therefore that in matters of Religion, no man's right is abridged by the institution of Civil Society."230

This striking passage illuminates the radical foundations of Madison's writings on religious liberty. While it does not prove that Madison supported free exercise exemptions, it suggests an approach toward religious liberty consonant with them. If the scope of religious liberty is defined by religious duty (man must render to God "such homage ... as he believes to be acceptable to him"), and if the claims of civil society are subordinate to the claims of religious freedom, it would seem to follow that the dictates of religious faith must take precedence over the laws of the state, even if they are secular and generally applicable. This is the central point on which Madison differs from Locke, Jefferson, and other Enlightenment advocates of religious freedom. ${ }^{231}$

227 Letter from James Madison to William Bradford (Jan. 24, 1774), in I MADIson PAPERS, supra note 226 , at I04, го6.

228 Id.

$229 \mathrm{~J}$. MAdison, Memorial and Remonstrance, supra note rog, at $183, \mathrm{I} 84$.

230 Id. at $184-85$.

231 Walter Berns, an astute scholar of Locke and the liberal Enlightenment, argues against free exercise exemptions on Lockean grounds: "Congress does not have to grant an exemption to someone who follows the command of God rather than the command of the law because the Congress established by the Constitution denies . . that God issues any such commands." W. BERNS, supra note 13 , at 48 (emphasis in original). "Liberalism," Professor Berns goes on to 
Additional evidence supports the conclusion that Madison believed freedom of religion to include exemption from generally applicable laws in some circumstances. As discussed more fully below, ${ }^{232} \mathrm{Mad}-$ ison supported a formulation of the Virginia Bill of Rights that allowed generous scope for free exercise exemptions and proposed an express religious exemption from military conscription for inclusion in the Bill of Rights. 233 These positions tend to confirm the "pro-exemptions" reading of the Memorial and Remonstrance.

Another passage in the Memorial and Remonstrance arguably contradicts such a reading. Virginia's proposed assessment bill made special provision for "Quakers and Menonists," who could use the funds appropriated from their members "in a manner which they shall think best calculated to promote their particular mode of worship," rather than being required, like other denominations, to use the money exclusively "for a Minister or Teacher of the Gospel of their denomination, or the providing places of divine worship."234 In response to this special provision, Madison commented:

As the Bill violates equality by subjecting some to peculiar burdens; so it violates the same principle, by granting to others peculiar exemptions. Are the Quakers and Menonists the only sects who think a compulsive support of their religions unnecessary and unwarantable? Can their piety alone be intrusted with the care of public worship? Ought their Religions to be endowed above all others, with extraordinary privileges, by which proselytes may be enticed from all others?235

This passage provides some support for the no-exemptions view, since it describes the "peculiar exemptions" in the bill as "extraordinary privileges" that violate the principle of religious equality. However, the meaning of the passage is ambiguous and must be weighed against evidence that Madison departed from the Lockean objection to exemptions. Instead of indicating a general objection to exemptions, the passage can be read as objecting only to the fact that the bill singled out two sects by name, giving them a preference over others that might have similar scruples. Alternatively, the quoted passage may

say, "began in the effort to subordinate religious opinion to the law." Id. at 5o. Professor Berns has no doubt correctly summarized Locke's position - and Jefferson's as well - but this position is at odds with Madison's. According to Madison, it is precisely because God does issue commands (though there will be disagreement over what they are) that the state must respect religious liberty, as a subordinate must respect the commands of a superior power.

232 See infra pp. $1462-63$.

233 See infra text accompanying note 466.

$234 \mathrm{Va}$. House of Delegates, A Bill Establishing a Provision for Teachers of the Christian Religion (December 24, 1784), reprinted in Everson v. Board of Educ., 330 U.S. 1, 28 app. at 72 (1947) (Rutledge, J., dissenting).

$235 \mathrm{~J}$. MADISON, Memorial and Remonstrance, supra note 109 , at $\mathrm{x} 86$. 
mean no more than that one reason to reject establishments is that they generate a need for otherwise unnecessary exemptions. The passage therefore does not tell us whether Madison would oppose exemptions from legitimate secular legislation that create unavoidable conflicts with conscience.

No other political figure played so large a role in the enactment of the religion clauses as Jefferson and Madison. ${ }^{236}$ To a large extent, Jefferson reflected the rationalist premises of Locke, and it is these premises that the modern courts and commentators have relied upon in arguing for a no-exemption interpretation of the free exercise clause. The evidence indicates, however, that Madison, with his more generous vision of religious liberty, more faithfully reflected the popular understanding of the free exercise provision that was to emerge both in state constitutions and the Bill of Rights.

\section{Legal Protections After Independence}

The Revolution inspired a wave of constitution-writing in the new states. Eleven of the thirteen states (plus Vermont) adopted new constitutions between 1776 and 1780 . Of those eleven, six (plus Vermont) included an explicit bill of rights; three more states adopted a bill of rights between I78I and I790. With the exception of Connecticut, every state, with or without an establishment, had a constitutional provision protecting religious freedom by 1789 , although two states confined their protections to Christians and five other states confined their protections to theists. ${ }^{237}$ There was no discernible difference between the free exercise provisions adopted by the states with an establishment and those without. The free exercise clauses of Massachusetts and New Hampshire were almost identical to those of

236 Fisher Ames of Massachusetts drafted the last version of the amendment to pass the House; his version was quite similar to the amendment that was ultimately ratified. His views, therefore, could be relevant. But Ames, who wrote numerous letters and essays on various issues of public importance, never made any reference in them to free exercise or to religious freedom. See F. Ames, WORKS OF Fisher AmEs (S. Ames ed. 1854). His biographer does not even mention his authorship of the free exercise clause. See W. BERNHARd, Fisher AMES: FEDERALIST AND STATESMAN: 1758-1808 (1965). Nor do his opinions regarding religion seem noteworthy. He was a member of the majority denomination in his state, the Congregational Church, and left late in life to join the Episcopal Church, apparently because of political differences with the pastor. See W. BERNHARD, supra, at 330-3r. Evidently, his role in drafting the free exercise clause was one of political peacemaker, rather than exponent of a particular vision of religious freedom.

${ }^{237}$ Maryland and Delaware explicitly limited their free exercise protections to Christians, although a related provision of the Delaware Declaration of Rights contains language that is not so confined. New Hampshire, Massachusetts, New Jersey, North Carolina, and Pennsylvania limited their free exercise protections to believers in God. New York, Georgia, Rhode Island, and South Carolina extended their protections to all religions. Virginia's Bill of Rights is ambiguous; it contains a theistic definition of religion but also contains language that may be broader in application. See infra pp. 1456-57 \& note 242. 
New Jersey, Pennsylvania, and Delaware. Freedom of religion was universally said to be an unalienable right; the status of other rights commonly found in state bills of rights, such as property or trial by jury, was more disputed and often considered derivative of civil society. 238

These state constitutions provide the most direct evidence of the original understanding, for it is reasonable to infer that those who drafted and adopted the first amendment assumed the term "free exercise of religion" meant what it had meant in their states. The wording of the state provisions thus casts light on the meaning of the first amendment.

\section{New York's 1777 Constitution was typical:}

[T] ]he free exercise and enjoyment of religious profession and worship, without discrimination or preference, shall forever hereafter be allowed, within this State, to all mankind: Provided, That the liberty of conscience, hereby granted, shall not be so construed as to excuse acts of licentiousness, or justify practices inconsistent with the peace or safety of this State. ${ }^{239}$

\section{Likewise, New Hampshire's provision stated:}

Every individual has a natural and unalienable right to worship GOD according to the dictates of his own conscience, and reason; and no subject shall be hurt, molested, or restrained in his person, liberty or estate for worshipping GOD, in the manner and season most agreeable to the dictates of his own conscience, ... provided he doth not disturb the public peace, or disturb others, in their religious worship. ${ }^{240}$

238 The New Hampshire Constitution of 1784 declared: “Among the natural rights, some are in their very nature unalienable, because no equivalent can be given or received for them. Of this kind are the RIGHTS OF CONSCIENCE." N.H. CONST. of I784, pt. I, art. IV, reprinted in 2 Federal and State Constitutions, silpra note 2, at 1280, 1280-8I. The Pennsylvania Constitution of $\mathrm{I} 790$ listed both liberty of conscience and the rights of property and reputation as among the "inherent and indefeasible rights." PA. CoNST. of 1790 , art. IX, $\S \S \mathrm{I}, 3$, reprinted in 2 Federal and State Constitutions, supra note 2, at 1548, 1554; see also I ANNALS of CoNG. 454 (J. Gales ed. I834) (speech by James Madison, June 8, 1789) ("Trial by jury cannot be considered as a natural right, but a right resulting from a social compact which regulates the action of the community, but is as essential to secure the liberty of the people as any one of the pre-existent rights of nature."); Madison, Property, National Gazette, Mar. 29, 1792, reprinted in 6 THE WRITINGS OF JAMES MADISON, supra note 109, at IOI, IOI-03 (treating property as a right "dependent on positive law"). See generally M. WhITE, The PHILosophy OF THE AMERICAN REVOLUTION 195-228 (1978) (discussing the distinction between unalienable and alienable rights, placing "the right to worship" in the former category, and recounting Jefferson's view that "property," an example from the latter category, should not be enumerated in the Declaration of Independence).

239 N.Y. CONST. of 1777 , art. XXXVIII, reprinted in 2 FEDERAL AND STATE CONSTITUTIONS, supra note 2 , at 1328,1338 .

240 N.H. Const. of 1784 , pt. I, art. V, reprinted in 2 FEDERAL and State Constitutions, supra note 2 , at $1280,128 \mathrm{r}$. 
As a final example, Georgia's religious liberty clause read: "All persons whatever shall have the free exercise of their religion; provided it be not repugnant to the peace and safety of the State."241 Other state provisions were similar. ${ }^{242}$ In addition to these state provisions, article

241 Ga. Const. of 1777 , art. LVI, reprinted in I Federal and State Constitutions, supra note 2 , at 377,383 .

242 Together with the provisions quoted in the text, the following is a complete collection of state free exercise provisions at the time of the adoption of the first amendment.

The Delaware Declaration of Rights and Fundamental Rules of $I 776$ provided:

2. That all Men have a natural and unalienable Right to worship Almighty God according to the Dictates of their own Consciences and Understandings; that no Man ought or of Right can be compelled to attend any religious Worship or maintain any Ministry contrary to or against his own free Will and Consent, and that no Authority can or ought to be vested in, or assumed by any Power whatever that shall in any Case interfere with, or in any Manner controul the Right of Conscience in the Free Exercise of Religious Worship.

3. That all Persons professing the Christian Religion ought forever to enjoy equal Rights and Privileges in this State, unless, under Colour of Religion, any Man disturb the Peace, the Happiness or Safety of Society.

Del. Declaration of Rights and Fundamental Rules of 1776 , $\S ~ 2,3$, reprinted in 5 THE FOUNDERS' CoNSTITUTION, supra note 72, at 70.

The Maryland Declaration of Rights of 1776 provided:

That, as it is the duty of every man to worship God in such manner as he thinks most acceptable to him; all persons, professing the Christian religion, are equally entitled to protection in their religious liberty; wherefore no person ought by any law to be molested in his person or estate on account of his religious persuasion or profession, or for his religious practice; unless, under colour of religion, any man shall disturb the good order, peace or safety of the State, or shall infringe the laws of morality, or injure others, in their natural, civil, or religious rights . . . .

Md. Declaration of Rights of 1776 , art. XXXIII, reprinted in I FEDERAL AND STATE ConstITUTIONS, supra note 2 , at 817,819 .

The Massachusetts Constitution of 1780 provided:

It is the right as well as the duty of all men in society, publicly and at stated seasons, to worship the Supreme Being, the great Creator and Preserver of the universe. And no subject shall be hurt, molested, or restrained, in his person, liberty, or estate, for worshipping God in the manner and season most agreeable to the dictates of his own conscience, or for his religious profession or sentiments, provided he doth not disturb the public peace or obstruct others in their religious worship.

Mass. Const. of 1780 , art. II, reprinted in I Federal and State Constitutions, supra note 2, at 956,957 .

The New Jersey Constitution of 1776 provided: "That no person shall ever, within this Colony, be deprived of the inestimable privilege of worshipping Almighty God in a manner agreeable to the dictates of his own conscience; nor, under any pretence whatever, be compelled to attend any place of worship, contrary to his own faith and judgment . . ." N.J. CoNST. of $\mathrm{I776}$, art. XVIII, reprinted in 2 FEDERAL AND STATE CONSTITUTIONS, supra note 2, at I3Io, I3I3.

The North Carolina Constitution of $x 776$ provided: "That all men have a natural and unalienable right to worship Almighty God according to the dictates of their own consciences." N.C. Const. of 1776 , art. XIX, reprinted in 2 FEDERAI AND STATE Constitutions, supra note 2 , at 1409 , 1410 .

The Pennsylvania Constitution of 1776 provided:

That all men have a natural and unalienable right to worship Almighty God according to the dictates of their own consciences and understanding: And that no man ought or of right can be compelled to attend any religious worship, or erect or support any place of worship, or maintain any ministry, contrary to, or against, his own free will and 
I of the Northwest Ordinance of 1787 , enacted contemporaneously with the drafting of the Constitution and re-enacted by the First Congress, provided: "No person, demeaning himself in a peaceable and orderly manner, shall ever be molested on account of his mode of worship, or religious sentiments, in the said territory."243

While differing in their particulars, these constitutional provisions followed the model set by the early Rhode Island, Carolina, and New Jersey charters, both in the scope of the liberty and in its limitations. Each of these elements warrants attention.

I. Scope of the Liberty. - Each of the state constitutions first defined the scope of the free exercise right in terms of the conscience

consent: Nor can any man, who acknowledges the being of a God, be justly deprived or abridged of any civil right as a citizen, on account of his religious sentiments or peculiar mode of religious worship: And that no authority can or ought to be vested in, or assumed by any power whatever, that shall in any case interfere with, or in any manner controul, the right of conscience in the free exercise of religious worship.

PA. Const. of 1776 , art. II, reprinted in 2 FEDERAL AND STATE Constitutions, supra note 2 , at $\mathrm{x} 54 \mathrm{O}$, I54I.

The Charter of Rhode Island and Providence Plantations of 1663 provided:

[N]oe person within the sayd colonye, at any tyme hereafter, shall bee any wise molested, punished, disquieted, or called in question, for any differences in opinione in matters of religion, and doe not actually disturb the civill peace of our sayd colony; but that all and everye person and persons may, from tyme to tyme, and at all tymes hereafter, freelye and fullye have and enjoye his and theire owne judgments and consciences, in matters of religious concernments, throughout the tract of lande hereafter mentioned; they behaving themselves peaceblie and quietlie, and not useing this libertie to lycentiousnesse and profanenesse, nor to the civill injurye or outward disturbeance of others; any lawe, statute, or clause, therein contayned, or to bee contayned, usage or custome of this realme, to the contrary hereof, in any wise, notwithstanding.

R.I. Charter of i663, reprinted in 2 FEDERAL and State Constitutions, supra note 2, at 1595, 1596-97.

The South Carolina Constitution of 1790 provided:

The free exercise and enjoyment of religious profession and worship, without discrimination or preference, shall forever hereafter be allowed within this State to all mankind: Provided, That the liberty of conscience thereby declared shall not be so construed as to excuse acts of licentiousness, or justify practices inconsistent with the peace or safety of this State.

S.C. Const. of 1790 , art. VIII, § $\mathrm{I}$, reprinted in 2 FEDERAL and STATE Constitutions, supra note 2 , at $1628,1632-33$ (emphasis in original). The South Carolina Constitution of 1778 contained a much more limited religious freedom clause, similar to the Fundamental Constitutions of 1669 . See S.C. CoNST. of 1778 , art. XXXVIII, reprinted in 2 FEderal AND STATE Constitutions, supra note 2 , at $1620,1626-27$. References in text are to the 1790 constitution unless otherwise specified.

The Virginia Bill of Rights of 1776 provided:

That religion, or the duty which we owe to our Creator, and the manner of discharging it, can be directed only by reason and conviction, not by force or violence; and therefore all men are equally entitled to the free exercise of religion, according to the dictates of conscience; and that it is the mutual duty of all to practise Christian forbearance, love, and charity towards each other.

Va. Bill of Rights of 1776 , $§ 16$, reprinted in 2 FEDERAL AND STATE ConstituTions, supra note 2 , at 1908,1909 .

243 Northwest Territorial Ordinance of 1787 , art. I, reprinted in I Federal aND STATE Constitutions, supra note 2 , at $429,43 \mathrm{I}$. 
of the individual believer and the actions that flow from that conscience. None of the provisions confined the protection to beliefs and opinions, as did Jefferson, nor to expression of beliefs and opinions, as some recent scholars have suggested. ${ }^{244}$ Indeed, the language appears to have been drafted precisely to refute those interpretations. Maryland, for example, prohibited punishment of any person "on account of his religious persuasion or profession, or for his religious practice."245 Opinion, expression of opinion, and practice were all expressly protected. The key word "exercise," found in six of the constitutions, was defined in dictionaries of the day to mean "action."246 Two of the other constitutions used terms as broad or broader - Maryland referred to religious "practice," Rhode Island to matters of "religious concernment." 247

Nor did these constitutions follow Locke in defining the scope of free exercise negatively, as a sphere of otherworldly concern that does not affect the public interest. The free exercise provisions defined the free exercise right affirmatively, based on the scope of duties to God perceived by the believer. The New Hampshire formulation defined the believer's right by "the dictates of his own conscience, and reason";248 it extended to all "matters of religious concernment," according to Rhode Island. These could, and often would, include matters of concern to the public. This is consistent with the proposition, reflected in Madison's Memorial and Remonstrance, that the right of free exercise precedes and is superior to the social contract. ${ }^{249}$

Although the free exercise right plainly extends to some forms of conduct, the scope of protected conduct in these clauses is less clear. The provisions fall into two categories. Four states - Virginia, Georgia, Maryland, and Rhode Island - protected all actions stemming from religious conviction, subject to certain limitations. ${ }^{250}$ The Virginia Bill of Rights, the model for three of the state proposals for the first amendment and presumably the greatest influence on Madison, is especially clear on this point. It provides that "all men are equally entitled to the free exercise of religion, according to the dictates of conscience" and defines "religion" as "the duty which we owe to our

244 See Marshall, Solving the Free Exercise Dilemma: Free Exercise as Expression, 67 MrNN.

L. REv. 545 (1983):

$245 \mathrm{Md}$. Declaration of Rights of 1776 , art. XXXII, reprinted in I FEDERAI AND STATE

ConstituTIONS, supra note 2 , at $8 \mathrm{I} 7,8 \mathrm{I} 9$ (emphasis added).

246 See infra text accompanying notes 407-409.

247 See Md. Declaration of Rights of 1776 , art. XXXIII, reprinted in I FEDERAL AND STATE Constitutions, supra note 2 , at 817 , 819; R.I. Charter of 1663 , in 2 FEderal and STATE ConstituTions, supra note 2 , at 1595,1596 .

248 N.H. Const. of 1784 , art. V, reprinted in 2 FEDERAL and State Constitutions, supra note 2 , at 1280,1281 (emphasis added).

249 See supra text accompanying notes 229-230.

250 See supra text accompanying note $24 \mathrm{I} \&$ note 242 . 
Creator, and the manner of discharging it."251 In the biblical tradition, "duties" to God included actions, perhaps all of life, and not just speech and opinion. So according to Virginia, the right of free exercise extended to all of a believer's duties to God and included a choice of means as well as ends.

By contrast, eight states - New York, New Hampshire, Delaware, Massachusetts, New Jersey, North Carolina, Pennsylvania, and South Carolina - plus the Northwest Ordinance, confined their protection of conduct to acts of "worship." The word "worship" usually signifies the rituals or ceremonial acts of religion, such as the administration of sacraments or the singing of hymns, and thus would indicate a more restrictive scope for the free exercise provisions. ${ }^{252}$

The limitation to "worship" was not carried over into the federal free exercise clause, which in this respect most closely resembles the Georgia provision. ${ }^{253}$ No direct evidence suggests whether the adoption of the broader formulation was deliberate, but this seems consistent with the general theological currents of Protestant America, which were "low church" and anti-ritualistic. One of the main elements of the Great Awakening was the insistence that duties to God extend beyond the four walls of the church and the partaking of the sacraments. From the evangelical Protestant perspective, "worship" would not have been sharply distinguished from "the duty we owe to our Creator."254 The ready availability of narrow models in the recently enacted Northwest Ordinance and the constitution of final drafter Fisher Ames' home state of Massachusetts makes it likely that the choice of broader language was deliberate. The federal free exercise

251 Va. Bill of Rights of $1776, \S 16$, reprinted in 2 FEDERAL AND STATE Constitutions, supra note 2, at 1908, x909. The definition of "religion" resembles the one provided by James Buchanan in 1757 : "Piety, godliness, the worship of God, and the practice of any duty in obedience to his commands." J. Buchanan, Linguae Britannicae Vera Pronunciatio (R. Alston ed. 1967) (London 1757). Under this definition, the exercise of "religion" would include both "worship" and "the practice of any duty" to God.

252 Samuel Johnson's A Dictionary of THE English Language (Philadelphia i805) defines the verb "worship" as "[t]0 adore; to honour or venerate with religious rites." Id. Other dictionaries of the day are less specific in the connection to religious ritual. See J. Buchanan, supra note 251 (defining "worship" as "[t]o adore or praise the Almighty"); N. WEBSTER, A Dictionary OF THE ENGlish Language 301 (New Haven 1807) (defining "worship" as "to adore, perform adoration"). The latter two definitions make no direct reference to religious ceremonials. Modern definitions, like Johnson's, are more specific. Webster's Third New International Dictionary defines "worship" as "the reverence or veneration tendered a divine being or supernatural power; also: an act, process, or instance of expressing such veneration by performing or taking part in religious exercises or ritual." WEBSTER's THIRD NEW INTERNATional Dictionary of the ENGLish Language 2637 (P. Gove ed. r986) (emphasis in original).

253 See supra text accompanying note $24 \mathrm{I}$.

254 R. MEHL, The Sociology OF ProtestantisM I07-08 (J. Farley trans. 1970) (explaining that "worship" is understood as "[a]ll that one calls 'the Christian life,' with all its ethical components"). 
clause seems in every respect to have followed the most expansive models among the states.

Indeed, even in the states that apparently limited free exercise to acts of "worship," it is not clear that the limitation had any actual effect. In none of the state free exercise cases in the early years of the Republic did the lawyers argue or the courts hold that religiously motivated conduct was unprotected because it was not "worship." Since the scope and nature of religious duty was itself a contested issue among religions, it seems unlikely that the state provisions intended to interject a judicial discrimination among forms of religious practice, and especially unlikely that this interjection would favor ritual over pious conduct. Interestingly, Pennsylvania (a state whose substantial Quaker population had an interest in exemptions) revised its constitutional protection for liberty of conscience in I790, removing the language that had limited it to acts of worship. ${ }^{255}$ Kentucky borrowed this broader language for its first constitution in I792. ${ }^{256}$ This may suggest a movement toward broader protections, simultaneous with the ratification of the first amendment.

In any event, it would be difficult on this evidence to conclude that the framers of the free exercise clause intended it to be confined to acts of "worship." That would require the assumption that Fisher Ames and the First Congress accidentally failed to use familiar language that would have precisely expressed their meaning and adopted instead new language that went beyond their intentions. Either the broader meaning was intended, or no thought was given to the matter at all.

2. Limits on the Liberty. - The second common element in state free exercise provisions is that the provisions limit the right by particular, defined state interests. Nine of the states limited the free exercise right to actions that were "peaceable" or that would not disturb the "peace" or "safety" of the state. ${ }^{257}$ Four of these also expressly disallowed acts of licentiousness or immorality; ${ }^{258}$ two for-

255 The 1776 Declaration of Rights of the Inhabitants of the State of Pennsylvania states that "no authority can or ought to be vested in, or assumed by any power whatever, that shall in any case interfere with, or in any manner controul, the right of conscience in the free exercise of religious worship." A Declaration of Rights of the Inhabitants of the State of Pennsylvania of 1776 , reprinted in 2 FEDERAL AND STATE CONSTITUTIONS, supra note 2 , at $154 \mathrm{I}$, $154 \mathrm{I}$. The I790 Pennsylvania Constitution states that "no human authority can, in any case whatever, control or interfere with the rights of conscience." PA. CONST. of I790, art. IX, $\S_{3}$, reprinted in 2 Federal and State Constitutions, supra note 2, at 1548, i554.

256 See Ky. Const. of 1792 , art. XII, reprinted in I FEDERAL aND STATE Constitutions, supra note 2 , at 647,654 .

257 The nine states are New York, New Hampshire, Georgia, Delaware, Maryland, Massachusetts, New Jersey, Rhode Island, and South Carolina. See supra p. I456 \& note 242.

258 The four states are New York, Maryland, Rhode Island, and South Carolina. See supra text accompanying note 239 \& note 242 . 
bade acts that would interfere with the religious practices of others; ${ }^{259}$ one forbade the "civil injury or outward disturbance of others"; 260 one added acts contrary to "good order"; 261 and one disallowed acts contrary to the "happiness," as well as the peace and safety, of society. ${ }^{262}$

These provisos are the most revealing and important feature of the state constitutions. They further confirm that the free exercise right was not understood to be confined to beliefs. Beliefs without more do not have the capacity to disturb the public peace and safety. As Virginia's Bill for Establishing Religious Freedom, drafted by Jefferson, stated, "it is time enough for the rightful purposes of civil government for its officers to interfere when principles break out into overt acts against peace and good order."263 If the basic right did not extend to "overt acts," the provisos would be unnecessary.

Moreover, the state provisions make sense only if free exercise envisions religiously compelled exemptions from at least some generally applicable laws. Since even according to the Lockean no-exemptions view, religious persons cannot be prohibited from engaging in otherwise legal activities, the provisos would only have effect if religiously motivated conduct violated the general laws in some way. The "peace and safety" clauses identify a narrower subcategory of the general laws; the free exercise provisions would exempt religiously motivated conduct from these laws up to the point that such conduct breached public peace or safety.

The language of these provisos cannot be dismissed as boilerplate, synonymous with "an assertion of interest on the part of the public." The debates surrounding the drafting of these provisos suggest that they served as independent criteria for evaluating assertions of legislative power. The debate over the free exercise provision of the Virginia Bill of Rights of 1776 most clearly demonstrates the understanding of the states that passed these provisos. George Mason, chief architect of the religious liberty clause of the Declaration, proposed "that all men should enjoy the fullest toleration in the exercise of religion, according to the dictates of conscience, unpunished and unrestrained by the magistrate, unless under color of religion any man disturb the peace, the happiness, or safety of society."264 Madison objected to the proposal on two grounds. First, he criticized the use of the word "toleration" for reasons already discussed. ${ }^{265} \mathrm{He}$ offered

${ }^{259}$ The two states are New Hampshire and Massachusetts. See supra text accompanying note $240 \&$ note 242 .

${ }^{260}$ The state is Rhode Island. See supra note 242.

261 The state is Maryland. See id.

262 The state is Delaware. See id.

263 Jefferson, A Bill for Establishing Religious Freedom (June 12, 1779), reprinted in 5 THE Founders' Constitution, supra note 72 , at 77 .

${ }^{264} \mathrm{~S}$. COBB, supra note $\mathrm{I} 7$, at $49 \mathrm{I}$.

265 See id. at 492. 
a substitute that read that "all men are equally entitled to the full and free exercise of religion according to the dictates of conscience."266 This change was accepted, with minor alteration. Second, Madison criticized the breadth of Mason's proposed state interest limitation. Madison proposed instead that free exercise be protected "unless under color of religion the preservation of equal liberty and the existence of the State are manifestly endangered." 267 This is obviously a much narrower state interest exception than Mason's. While "peace" and "safety" refer to the fundamental peacekeeping functions of government, "happiness" is a term as compendious as all of public policy. ${ }^{268}$ The "peace, happiness, or safety of society" is therefore a standard that would encompass virtually all legitimate forms of legislation. The "preservation of equal liberty" and "manifest endangerment of the existence of the State," on the other hand, is a standard that only the most critical acts of government can satisfy.

The Virginia legislature ultimately passed a religious liberty guarantee that did not spell out the nature of the state interest that could outweigh a free exercise claim. Apparently, the legislature could not decide between the Mason and Madison formulations and compromised through silence. It is fair to assume, however, that the state's interest must fall somewhere between "the peace, the happiness, or safety of society" - Mason's broad formulation - and "manifest danger" to the "preservation of equal liberty, and existence of the State" - Madison's more limited formulation. If so, Virginia was typical of its sister states. While none adopted a proviso as restrictive as Madison's, only one (Delaware) adopted a proviso as broad as Mason's. Almost all opted for the terms "peace" or "safety," presumably on the ground that "happiness" was too broad. In any event, the dispute between Madison and Mason would not have mattered if the proviso were of no legal significance, and the proviso would have been of no legal significance if the "full and free exercise of religion" did not include the right of exemption from generally applicable laws that conflict with religious conscience.

$266 I d$.

267 Id. In a private letter many years later, Madison endorsed a different formulation under which religion is immune from governmental authority "in every case where it does not trespass on private rights or the public peace." Letter from James Madison to Edward Livingston (July Io, 1822), in 9 The WRITINGS OF JAMEs MADISON, supra note rog, at 98, Ioo.

268 Samuel Johnson's two-volume A Dictionary of THE English LANGUaGe (London I755), chooses two of five exemplars of the use of the word "happiness" from political sources. It quotes Richard Hooker to the effect that: "Happiness is that estate whereby we attain, so far as possibly may be attained, the full possession of that which simply for itself is to be desired, and containeth in it after an eminent sort, the contentation of our desires, the highest degree of all our perfection." Id. It also quotes John Locke: "The various and contrary choices that men make in the world, argue that the same thing is not good to every man alike: this variety of pursuits shews, that every one does not place his happiness in the same thing." Id. (emphasis in original). 
The wording of the state constitutions also provides some guidance regarding when the government's interest is sufficiently strong to override an admitted free exercise claim. The modern Supreme Court has stated only that the government's interest must be "compelling," "of the highest order," "overriding," or "unusually important."269 These formulations are unnecessarily open-ended, leading to grudging and inconsistent results. The historical sources suggest that the government's interest can be more precisely delimited in a few specific areas, although other cases will remain difficult to resolve. ${ }^{270}$

The most common feature of the state provisions was the government's right to protect public peace and safety. As Madison expressed it late in life, the free exercise right should prevail "in every case where it does not trespass on private rights or the public peace."271 This indicates that a believer has no license to invade the private rights of others or to disturb public peace and order, no matter how conscientious the belief or how trivial the private right on the other side. There is no free exercise right to kidnap another person for the purposes of proselytizing, or to trespass on private property whether it be an abortion clinic or a defense contracting plant - to protest immoral activity. Conduct on public property must be peaceable and orderly, so that the rights of others are not disturbed.

Where the rights of others are not involved, however, the free exercise right prevails. The state constitutional provisions give no warrant to paternalistic legislation touching on religious concerns. They protect the "public" peace and safety but respect the right of the believer to weigh spiritual costs without governmental interference. Thus, some modern free exercise controversies, such as the refusal by Jehovah's Witnesses to receive blood transfusions ${ }^{272}$ or the enforcement of minimum wage laws in a religious community, ${ }^{273}$ should be easy to resolve and require no subjective judicial judgments about the importance of public policy. Moreover, the early free exercise clauses seem to allow churches and other religious institutions to define their own doctine, membership, organization, and internal requirements

${ }^{269}$ Goldman v. Weinberger, 475 U.S. 503, 529-30 (r 986 ) (O'Connor, J., dissenting) (summarizing free exercise tests from earlier cases).

270 For another discussion of governmental interest in light of the early state constitutions, see RePORT TO THE ATtORNEY GeNERAL, cited above in note 17 , at 61-68.

271 Letter from James Madison to Edward Livingston (July Io, 1822), in 9 ThE WRITINGS OF JAMES MADison, supra note rog, at 98 , 100.

272 But see In re President and Directors of Georgetown College, 33I F.2d 1000 (D.C. Cir.), cert. denied, 377 U.S. 978 (1964); John F. Kennedy Memorial Hosp. v. Heston, 58 N.J. 576, 279 A.2d 670 (I97I).

273 But see Tony and Susan Alamo Found. v. Secretary of Labor, 47 I U.S. 290 (I985). The author of this Article was the principal author of the Secretary's brief in that case but believes the position was wrong. 
without state interference. As Jefferson wrote to the Reverend Samuel Miller, "the government of the United States [is] interdicted by the Constitution from intermeddling with religious institutions, their doctrines, discipline, or exercises."274 That their internal practices may seem unjust or repugnant to the majority should be of no moment. ${ }^{275}$ Only a handful of states allowed laws against "licentiousness" or immorality to override free exercise claims, and those provisions may well have referred to public displays of immoral behavior.

Obvious connections exist between the scope of the free exercise right defined by these provisions and the wider liberal political theory of which they are an expression. The central conception of liberalism, as summarized in the Declaration of Independence, is that government is instituted by the people in order to secure their rights to life, liberty, and the pursuit of happiness. Governmental powers are limited to those needed to secure these legitimate ends. In contrast to both ancient and modern non-liberal regimes, government is not charged with promotion of the good life for its citizens. Except as needed for mutual protection and a limited class of common interests, government must leave the definition of the good life to private institutions, of which family and church are the most conspicuous. Even in the absence of a free exercise clause, liberal theory would find the assertion of governmental power over religion illegitimate, except to the extent necessary for the protection of others.

To eighteenth-century evangelicals, this issue was posed in theological terms but the answer was much the same. God instituted government for the punishment of wrongdoing, ${ }^{276}$ which they interpreted to mean injury to others. ${ }^{277}$ While the evangelicals could not accede to the Lockean proposition that the reach of governmental authority is defined by the judgments of civil authorities, they found the liberal theory of government a way to reconcile their insistence on the primacy of conscience with their equal insistence on the divinely ordained authority of government. Thus, when describing the legiti-

274 Letter from Thomas Jefferson to the Rev. Samuel Miller (Jan. 23, I808), in II WoRks OF JeFFERSON, supra note 206 , at 7,7 .

275 Bul cf. Bob Jones Univ. v. United States, 46r U.S. 574 (1983) (finding no violation of the free exercise clause when the IRS refused to grant charitable status to a religious school due to its proscription of interracial dating).

276 "Let every soul be subject unto the higher powers. For there is no power but of God: the powers that be are ordained of God. Whosoever therefore resisteth the power, resisteth the ordinance of God: and they that resist shall receive to themselves damnation." Romans I3:I-2.

277 See, e.g., J. LELAND, supra note 174, at II8 ("The legitimate powers of government extend only to punish men for working ill to their neighbors . . . ."); I. BAckUS, supra note 175, at 313-14 (interpreting Romans $13: 1-10$ as "clearly show[ing] that the crimes which fall within magistrates' jurisdiction to punish are only such as work ill to our neighbors," while "church government respects our behavior toward God as well as man"). 
mate reach of government, the evangelical writers sounded little different from the American followers of Locke. ${ }^{278}$

The "peace and safety" limitations of the state constitutions are therefore neither simple restatements of unbridled governmental supremacy in a clash with religious precepts, nor mere expedient exceptions to what would otherwise be unlimited rights of religiously motivated conduct. Both the affirmative free exercise protections and the peace and safety limitations follow logically from the liberal and evangelical theories of government, which reached similar conclusions from different premises about the origin and scope of legitimate government.

\section{E. Actual Free Exercise Controversies}

An examination of actual free exercise controversies in the preconstitutional period bears out these conclusions. To be sure, the issue of exemptions did not often arise. ${ }^{279}$ The American colonies were peopled almost entirely by adherents of various strains of Protestant Christianity. ${ }^{280}$ The Protestant moral code and mode of worship was, for the most part, harmonious with the mores of the larger society. Even denominations like the Quakers, whose theology and religious practice differed sharply from the others, entertained similar beliefs about public decorum. ${ }^{281}$ Moreover, the governments of that era were far less intrusive than the governments of today. Thus, the occasions when religious conscience came into conflict with generally applicable secular legislation were few.

Nonetheless, the issue of exemptions did arise, primarily centered around three issues: oath requirements, military conscription, and religious assessments. The resolution of these conflicts suggests that exemptions were seen as a natural and legitimate response to the tension between law and religious convictions.

278 For example, compare the passages quoted in note 277 above with Jefferson's statement that "[t]he legitimate powers of government extend to such acts only as are injurious to others." T. JefFerson, Notes on the State of Virginia, supra note 216 , at 159.

279 Professor Marshall relies heavily on this point in his attack on free exercise exemptions. See Marshall, supra note 17 , at 19-20. But of course, few instances are not the same as no instances.

${ }^{280}$ For a discussion of the number of churches of each denomination at the end of the colonial period, see I A. Stokes, ChURCh aNd State in the UNIted STATES 273 \& n.50 (1950). The largest groups, in order, were Congregationalists, Presbyterians, Baptists, and Anglicans. Out of 3,005 congregations, only 5o were Roman Catholic. See id. There were fewer than 2,000 Jews, concentrated in five cities - New York, Philadelphia, Newport, Charleston, and Savannah. See M. Borden, supra note 75 , at 6.

281 See T. CURRX, supra note 17 , at 81 . In the early days of the American colonies, the Quakers' behavior had been more unconventional. See W. Russell, supra note 65 , at 3 n.1 (describing offensive Quaker practices, including interrupting others' worship services and going naked in public in protest against cruelty and sinfulness). 
I. Oaths. - By far the most common source of friction was the issue of oaths. The oath requirement was the principal means of ensuring honest testimony and of solemnizing obligations. At a time when perjury prosecutions were unusual, extratemporal sanctions for telling falsehoods or reneging on commitments were thought indispensable to civil society. Quakers and certain other Protestant sects, however, conscientiously refused to take oaths, ${ }^{282}$ producing more serious consequences than it might at first seem. A regime requiring oaths prior to court testimony effectively precluded these groups from using the court system to protect themselves and left them vulnerable to their adversaries, "who could sue them for property and never doubt the result."283 There are three possible responses. First, the government could eliminate the oath-taking requirement for everyone, making oath-taking purely voluntary. Second, the government could continue to insist on the oath requirement, making it impossible for dissenters to give evidence in court or participate in any civic activity involving an oath. Third, the government could continue the oath requirement for the majority, allowing those with religious scruples to comply by an alternative procedure. According to the no-exemption view, only the first two possibilities are available. But the first possibility is disruptive of the entire judicial system and the second is unnecessarily harsh to the dissenters.

The third alternative - to create a religious exception to the oath requirement - was in fact adopted in most of the colonies. As early as the seventeenth century the proprietors of the Carolina colony permitted Quakers to enter pledges in a book in lieu of swearing an oath. Similarly, New York passed a law in I69I permitting Quakers to testify by affirmation in civil cases, ${ }^{284}$ and in 1734 passed a law permitting Quakers to qualify for the vote by affirmation instead of oath. ${ }^{285}$ Jews in Georgia received dispensation to omit the words "on the faith of a Christian" from the naturalization oath required in I740. 286 In I743, Massachusetts, one of the states with a strong established church tradition, substituted an affirmation requirement for "Quakers [who] profess to be in their consciences scrupulous of

282 Their refusal to take oaths was based on Matthew 5:33-37:

Again, ye have heard that it hath been said by them of old time, Thou shalt not forswear thyself, but shalt perform unto the Lord thine oaths: But I say unto you, swear not at all; neither by heaven; for it is God's throne: Nor by the earth; for it is his footstool: neither by Jerusalem; for it is the city of the great King. Neither shalt thou swear by thy head, because thou canst not make one hair white or black. But let your communication be, Yea, yea; Nay, nay; for whatsoever is more than these cometh of evil.

Id.

283 R. Brugger, Maryland: A Middle Temperament 30 (I988).

284 See T. CURRY, supra note 17 , at 64 .

285 See id. at 71 .

286 See R. STRICKLAND, supra note 62, at 29. 
taking oaths."'287 By I789, virtually all of the states had enacted oath exemptions. ${ }^{288}$

2. Military Conscription. - The exemption issue also arose in connection with military conscription. Exemption from conscription provides a particularly telling example due to the entirely secular nature of conscription, its importance to preservation of the state in times of war, and the high costs the granting of exemptions imposes on others. Several denominations in colonial America, most prominently the Quakers and Mennonites, refused on religious grounds to bear arms. As early as I670-80, Quakers in several states asserted that liberty of conscience exempted them from bearing arms. Rhode Island, ${ }^{289}$ North Carolina, ${ }^{290}$ and Maryland ${ }^{291}$ granted the exemptions; New York refused.292 It is presumably not coincidental that Rhode Island, North Carolina, and Maryland had explicit free exercise or liberty of conscience clauses in the seventeenth century, while New York did not.

In Georgia, the Moravians claimed a right to be exempt from military service during the troubles with Spanish Florida, and when they were denied, the entire Moravian community departed Georgia between I737 and I740 and moved to Pennsylvania. ${ }^{293}$ Pennsylvania, where Quakers were most numerous and influential, went without a militia until $\mathrm{I} 755$, when one was organized on a voluntary basis. ${ }^{294}$ The issue arose in New York again in I734, and again the Quakers were denied exemption from penalties imposed for refusal to train for military service. ${ }^{295}$ The colony finally relented in 1755 , provided the objector would pay a commutation fee or send a substitute. ${ }^{296}$ Massachusetts and Virginia soon adopted similar policies. ${ }^{297}$ New Hampshire exempted Quakers from conscription in I759.298 Later, the Continental Congress was to grant exemptions in these words:

${ }^{287} \mathrm{~T}$. CURRY, supra note $\mathrm{I}$, at 90 (citing I MASSACHUSETTS ACTS AND RESOLVES 305 ; and 2 id. at $494-95)$.

288 See Adams \& Emmerich, supra note 17 , at $1631-32$.

${ }^{289}$ See Russell, Development of Conscientious Objector Recognition in the United States, 20 Geo. WASH. L. REv. 409, 412-13 (1952). Roger Williams opposed militia exemptions. See Adams \& Emmerich, supra note 17 , at 1624,1630 .

${ }^{290}$ See T. CURRY, supra note 17 , at 56 .

291 S. COBB, supra note 17 , at 380 \& n.2.

${ }^{292}$ See T. CURRY, supra note $\mathrm{I} 7$, at 63.

${ }^{293}$ See R. STRICKLAND, supra note 62, at $76-78$.

294 See Russell, supra note 289 , at 413.

295 See S. COBB, supra note 17 , at 356 .

296 See Act of Feb. I9, I755, reprinted in U.S. Selective Service SySTEM, 2 BackGRounds of Selective Service: Military Obligation pt. 9, at 186, 203-04 (A. Vollmer ed. 1947) [hereinafter SELECTIVE SERviCE].

297 See Act of Nov. 3I, I757, reprinted in SELECTIVE SERviCE, supra note 296, pt. 6, at 195, I95-97 (Massachusetts); Act of Nov. 1776, reprinted in SELECTIVE SERvicE, stipra note 296 , pt. 14, at 249, 249-53 (Virginia).

298 An Act for the More Speedy Levying One Thousand or at Least Eight Hundred Men 
As there are some people, who, from religious principles, cannot bear arms in any case, this Congress intend no violence to their consciences, but earnestly recommend it to them, to contribute liberally in this time of universal calamity, to the relief of their distressed brethren in the several colonies, and to do all other services to their oppressed Country, which they can consistently with their religious principles. ${ }^{299}$

The language as well as the substance of this policy is particularly significant, since it recognizes the superior claim of religious "conscience" over civil obligation, even at a time of "universal calamity," and leaves the appropriate accommodation to the judgment of the religious objectors.

3. Religious Assessments. - A third example of a religious exception recognized under the preconstitutional free exercise provisions is found only in states with established churches. Such states often required the citizens to make payments for the support of ministers either of the established church or of their own denomination. Not uncommonly, however, these states accommodated the objection of members of sects conscientiously opposed to compelled tithes. For example, from $\mathrm{I}_{727}$ on, Massachusetts and Connecticut exempted Baptists and Quakers from ministerial taxes. This exception was expressly, if grudgingly, made in recognition of the "alleged scruple of conscience" of these sects. ${ }^{300}$ From 1692 on, New Hampshire exempted anyone who could prove in a contested proceeding that he was "conscientiously" of "a different persuasion," attended services of his own faith regularly ("constantly," in the words of the statute), and made financial contributions toward its support. 301 New Hampshire also exempted Quakers who served as constables from the duty of collecting the assessments from others. ${ }^{302}$ Virginia exempted Huguenots in I700, German Lutherans in I730, and all dissenters from the Anglican Church in 1776.303

Inclusive of Officers to be Employd in His Majestys Service in the Current Year, 32 Geo. 2. Orig. Acts, vol. 4, p. 55; recorded Acts, vol. 2, p. 412 ; N.H. Province Laws I96, I98 (enacted Mar. 9, 1759).

299 See Resolution of July 18 , I775, reprinted in 2 JoURNALS OF THE CONTINENTAL CONGRESS, 1774-I789, at I87, I89 (W. Ford ed. I905 \& photo. reprint I968).

300 See T. CuRRY, supra note 17 , at 89-90 (quoting $x$ MASSACHUSETTS ACTS AND Resolves 305; 2 JouRnals of THE CONTINENTAL CONGRESS, I774-1789, supra note 299, at 494-95). Cobb's account is slightly different from Curry's. See S. CoBB, supra note I7, at 234-35. Cobb reports that in 1727 , Massachusetts passed a law similar to one already existing in Connecticut, allowing Episcopalians to pay tithes to their own churches (instead of to the prevailing Congregational churches) and that Massachusetts extended this treatment to Quakers and Baptists in I728. Massachusetts exempted Quakers from any religious assessment whatsoever in 1731 , and "Anabaptists" in 1734. See id.

301 See S. CoвB, supra note 17 , at 298-99.

302 See An Act to Exempt Those People Called Quakers From Gathering the Rates for the Ministers of Other Perswations Within the Province of New Hampshire, 4 Geo. 2. Orig. Acts; vol. 2, p. 50; recorded Acts, vol. I, p. 329; N.H. Province Laws 530 (enacted May IO, 173I).

303 See S. CoBB, supra note 17 , at 98,492 . 
Exemptions were a far from perfect solution to the assessment problem. Having obtained inclusion in the certificate system, the Baptists of Massachusetts eventually concluded that the system would not work. In 1773 , the association of Baptist churches voted to urge their members to refuse to provide the certificates required for legal exemption. ${ }^{304}$ Through civil disobedience, the Baptists resolved to pressure the legislature to abolish mandatory tithes altogether.

The Baptists' objections arose from both practice and principle. Administration of the certificate system was in the hands of local officials and local courts, who gave vent to the general hostility against the Baptists. Certificates were sometimes ignored ${ }^{305}$ and more often rejected on technicalities. ${ }^{306}$ In addition, popular opposition (amounting in some instances to violence) made the certificate system unworkable. ${ }^{307}$ It became evident that exemptions would not be administered evenhandedly. Moreover, the Baptists objected to the requirement of certifying which "members" (itself a theologically loaded term) were "conscientiously" of the Baptist persuasion, a judgment they believed could only be made by God. ${ }^{308}$ These objections foreshadow two critiques of modern free exercise exemptions: that their administration is implicitly biased in favor of familiar religions, ${ }^{309}$ and that the "sincerity" requirement is an inappropriate governmental inquiry. 310 But in the case of religious assessments, these problems could be resolved by abolishing the system of ministerial taxes - a solution not always available for secular interferences with conscience.

It might be objected that the example of exemptions from religious assessments is inapt, because the generally applicable law is itself religious, not secular, and would be unconstitutional under the establishment clause today. This is a valid point, even though the assessment laws were most frequently defended in terms of the secular need to promote morality. ${ }^{311}$ The decisive question, however, is whether the people at the time of adoption of the first amendment would likely have considered exemptions, whether legislative or judicial, an appropriate remedy when law and conscience conflict. Those states with

304 See I W. McLoughlin, supra note 5 I, at 550-54.

305 See id. at 548.

$306 \mathrm{See} i d$. at 549 (describing a certificate deemed invalid because it was signed by two persons plus the Elder, rather than three); $i d$. at 549-50 (discussing a certificate rejected because it did not state that the persons listed "belonged to" the church); id. at 547-48 (discussing a certificate rejected because "it did not state that the persons listed were 'conscientiously' of the Baptist persuasion").

${ }^{307}$ See id. at 550 (describing instances of mob action).

308 See I. BACKUS, supra note 175 , at 333 .

${ }^{309}$ See, e.g., Tushnet, supra note 33 , at $38 \mathrm{I}-83$. The greater the variance between religious practices and the prevailing social norm, the greater will be the difficulty of accommodation.

310 See, e.g., Noonan, supra note 26 , at 718-20.

311 See T. CURRy, supra note 17 , at $139-4 \mathrm{r}$. 
established churches had free exercise provisions which were almost identical to the provisions in states without establishment; and the establishment states understood the principle of free exercise to entail exemption from religious assessments, solely for the benefit of those with religious scruples. If exemptions were a recognized form of free exercise protection in establishment states, they likely would also have been recognized in the others (although the occasions for exemptions would be less frequent). The fact that exemptions were also made available from military conscription laws (plainly secular) and from oath requirements (largely secular), as well as from other secular laws, supports the broader principle.

4. Other Religious Exemptions. - Other colonies and states responded to particular conflicts between religious convictions and generally applicable laws by exempting those faced with the conflict. The Trustees of Georgia, for example, allowed certain groups of Protestant refugees from the European Continent virtual rights of self-government, a form of wholesale exemption that enabled these dissenters from the Church of England to organize themselves in accordance with their own faith. ${ }^{312}$ A group from Salzburg formed the town of Ebenezer, described by one historian as "a state within a state, a sort of theocracy under the direction of their ministers with daily conferences of the entire congregation in which God's guidance was invoked at the beginning and end." 313 In 1764 , the colonial legislature of Rhode Island passed a statute waiving the laws governing marriage ceremonies for "any persons possessing [professing] the Jewish religion who may be joined in marriage, according to their own usages and rites." 314 In $\mathrm{x} 798$, the state legislature exempted Jewish residents from the operation of state incest law, "within the degrees of affinity or consanguinity allowed by their religion."315 This was important because Jewish law was understood to encourage the marriage between uncle and niece, a relationship illegal under Rhode Island law.

Similarly, both North Carolina ${ }^{316}$ and Maryland ${ }^{317}$ exempted Quakers from the requirement of removing their hats in court, which

312 See R. Strickland, supra note 62 , at $21-22,71-76,87$. These groups were required to obey the colonial laws regarding military service, "property, place and good government," but were otherwise free to govern themselves. Id. at 72 .

313 Id.

314 Hartogensis, Rhode Island and Consanguineous Jewish Marriages, 20 PUbliCation AM. JEWISH HIST. Soc'y 137, I44 (I9II).

315 An Act Regulating Marriage and Divorce, I798 R.I. Pub. Laws § 7; see also Hartogensis, supra note 314, at 139-40 (discussing the Rhode Island law as an early example of religious exemptions in family law); Weisbrod, Family, Church and State: An Essay on Constitutionalism and Religious Authority, 26 J. FAM. L. 74I, 744 n.6 (I988) (same).

316 See An Act to prescribe the affirmation of allegiance and fidelity to this state to be taken by the people called quakers, and for granting them certain indulgences therein mentioned, 1784 N.C. Laws ch. 209, at 488 .

317 See R. BRUGGER, supra note 283 , at 29-30. 
they considered a form of obeisance to secular authority forbidden by their religion. This exemption may seem trivial today, ${ }^{318}$ but it was an issue of historical and emotional importance to the Quakers of that day. One of the most notorious courtroom cases of religious intolerance in England involved William Penn's refusal to remove his hat when he appeared in court to face an indictment for speaking to an unlawful assembly. Penn came to court bareheaded, but knowing his religious scruple, the judge ordered a court official to place a hat on his head. Penn then refused to remove the hat in respect to the court. Although acquitted on the charge on which he was tried, Penn was held in contempt and imprisoned for refusing to doff his hat. ${ }^{319}$ This case became a cause célèbre in America, and the North Carolina and Maryland exemptions were no doubt passed as a result. 320

The history of oath requirements, military conscription, religious assessments, and other sources of conflict between religious convictions and general legislation demonstrates that religion-specific exemptions were familiar and accepted means of accommodating these conflicts. Rather than make oaths, military service, and tithes voluntary for everyone, which would undercut important public programs and objectives, and rather than coerce the consciences of otherwise loyal and law-abiding citizens who were bound by religious duty not to comply, the colonies and states wrote special exemptions into their laws. Lest the exemptions be extended too broadly, they confined the exemptions to denominations or categories known or proven to be "conscientiously" opposed. This aspect of the historical practice parallels in its purposes the requirement of "sincerity" under current law, ${ }^{321}$ although

318 Interestingly, the right to wear a hat has featured prominently in modern free exercise litigation. See, e.g., Goldman v. Weinberger, 475 U.S. 503 (1986) (denying an Orthodox Jewish officer the right to wear a yarmulke with his military uniform); Cooper v. Eugene School Dist., 3or Or. 358,723 P.2d 298 (1986) (upholding a revocation of tenure and teaching certificate when a Sikh teacher violated the dress statute by wearing a turban while teaching), appeal dismissed, 480 U.S. 942 ( 1987 ) (Brennan, Marshall, and O'Connor, JJ., dissenting).

319 An excellent summary of the case may be found in I. BRANT, THE BiLL of Rights 6267 (1965).

${ }^{320} \mathrm{It}$ is interesting that this subject came up for oblique discussion in the First Congress, during the debate over the Bill of Rights. Theodore Sedgwick of Massachusetts had ridiculed the Select Committee's list of freedoms to be protected, saying that "they might have declared that a man should have a right to wear his hat if he pleased; that he might get up when he pleased, and go to bed when he thought proper; but he would ask the gentleman whether he thought it necessary to enter these trifles in a declaration of rights." I ANNALs OF CoNG. 7596o (J. Gales ed. I834) (Aug. 15, 1789). John Page of Virginia responded:

The gentleman from Massachusetts . . . objects to the clause, because the right is of so trivial a nature. He supposes it no more essential than whether a man has a right to wear his hat or not; but let me observe to him that such rights have been opposed, and a man has been obliged to pull off his hat when he appeared before the face of authority; people have also been prevented from assembling together on their lawful occasions.

Id. at 760 . This was an evident reference to Penn's case. See I. BRANT, supra note 319 , at 53-55.

${ }^{321}$ See supra text accompanying notes $26-28$. 
the tendency to recognize only those beliefs that are a formal part of the religious dogma of the claimant's denomination has been superseded by a more individualistic view of religious conscience. ${ }^{322}$

An obvious objection to all these examples would be that they were initiated by the legislature. While these examples may refute the absolute no-exemption position, they are not inconsistent with the "judicial restraint" position. If, however, as seems to be the case, the exemptions were granted because legislatures believed the free exercise principle required them, it is reasonable to suppose that framers of constitutional free exercise provisions understood that similar applications of the principle would be made by the courts, once courts were entrusted with the responsibility of enforcing the mandates of free exercise.

\section{The Federal Free Exercise Clause}

\section{A. The Constitution of 1787}

The original Constitution drafted by the Convention in 1787 and ratified by the states in 1788 contained no provision protecting the general freedom of religion. It was not, however, entirely silent about religion. Two provisions of the Constitution reflect a spirit and purpose similar to that of the free exercise clause: the prohibition on religious tests for office in article VI, ${ }^{323}$ and the allowance of affirmations in lieu of oaths in articles I, II, and VI. ${ }^{324}$ Both provisions

322 See, e.g., Frazee v. Illinois Dep't of Employment Sec., Iog S. Ct. I5I4 (I989).

${ }^{323}$ Article VI provides: "no religious Test shall ever be required as a Qualification to any Office or public Trust under the United States." U.S. CoNST. art. VI, § 3. This provision was first proposed by Charles Pinckney of South Carolina as a freestanding amendment, see 2 I787: Drafting the U.S. Constitution 4487 (W. Benton ed. 1986) [hereinafter Drafting the Constitution], and ro days later, as an amendment to the article on the oath of office, see id. at 488. Debate was brief. Roger Sherman of Connecticut "thought it unnecessary, the prevailing liberality being a sufficient security against such tests," but Gouverneur Morris of Pennsylvania and Pinckney's second cousin, General Charles Cotesworth Pinckney, supported the motion, which passed unanimously. See id. at r488-89; 2 FARRAND RECORDS, supra note 160, at 457, 460-6I (Journal, Aug. 30, I787); id. at 46I, 468 (Madison's notes, Aug. 30, I787). Later, during the ratification debates, the provision generated some opposition from those who believed that atheists, "heathens," non-Christians, "Papists," or "Mahometans" should be excluded from office. See, e.g., 2 Elliot's Debates, supra note I65, at rrg (noting Col. Jones' opposition to the provision during the Massachusetts convention); 4 id. at 199 (noting Caldwell's argument against the provision during the North Carolina convention); id. at 215 (noting W. Lancaster's opposition during the North Carolina convention). On the importance of this provision, see C. ANTIEAU, A. Downey \& E. RoBerTs, cited above in note 16, at 92-ITo; and Bradley, The No Religions Test Clause and the Constitution of Religious Liberty: A Machine That Has Gone of Itself, 37 CASE W. REs. L. REv. 674 (1987).

324 Article I requires that the Senate "shall be on Oath or Affirmation" when sitting for the trial of impeachments. U.S. CoNST. art. I, $\S_{3}, \mathrm{cl}$. 6. As originally proposed by Gouverneur Morris and as reported by the Committee on Style, this provision required an oath. See I 
were designed to prevent restrictions hostile to particular religions and thus to make the government of the United States more religiously inclusive. Neither provision, however, used the device of a religionspecific exemption.

The framers' decision to ban religious tests was a dramatic departure from the prevailing practice in the states, eleven of which then banned non-Christians and at least four of which banned non-Protestants from office. ${ }^{325}$ While innovative in practice, however, the provision was unexceptional in theory. From the outset, the prevention of persecution, penalties, or incapacities on account of religion has served as a common ground among all the various interpretations of religious liberty. Religious tests for office are classic examples of laws that single out particular religious beliefs for peculiar disability, and they would be unconstitutional under any intelligible construction of the religion clauses. ${ }^{326}$ As Oliver Ellsworth of Connecticut, later Chief Justice of the United States, wrote during the ratification campaign:

[T] is to exclude persecution, and to secure to you the important right of religious liberty .... In our country every man has a right to worship God in that way which is most agreeable to his own conscience. If he be a good and peaceable citizen, he is liable to no penalties or incapacities on account of his religious sentiments; or in other words, he is not subject to persecution. ${ }^{327}$

DRAFTing THE Constitution, supra note 323 , at $640,64 \mathrm{I}$. The words "or affirmation" were added on September 14, I787, by unanimous vote of the Convention. See id. at 641 .

Article II provides:

Before he enter on the Execution of his Office, [the President] shall take the following Oath or Affirmation: "I do solemnly swear (or affirm) that I will faithfully execute the Office of President of the United States, and will to the best of my Ability, preserve, protect, and defend the Constitution of the United States."

U.S. CoNST. art. II, $\S \mathrm{I}, \mathrm{cl}$. 8. The allowance of an affirmation in lieu of an oath was part of the original provision as drafted by the Committee of Detail. See 2 Drafting THE ConstITUTION, supra note 323 , at 1488 .

Article VI provides: "The Senators and Representatives before mentioned, and the Members of the several State Legislatures, and all executive and judicial Officers . . . shall be bound by Oath or Affirmation, to support this Constitution." U.S. CoNST. art. VI, cl. 3. As originally proposed by the Committee of Detail, this provision required an oath. This appears to have been an oversight; the words "or affirmation" were added, apparently on the floor of the Convention, without separate vote. See 2 DRAFTing THE CONSTitution, supra note 323, at I488.

325 See Bradley, supra note 323 , at $68 \mathrm{I}-83$. By this time, Virginia had eliminated religious tests. New York allowed Jews but banned Catholics; Maryland banned Jews but allowed Catholics. See M. Borden, supra note 75, at 13-14.

326 See Torcaso v. Watkins, 367 U.S. 488 ( $196 \mathrm{I}$ ) (striking down Maryland's religious test under the first amendment). But cf. Davis v. Beason, 133 U.S. 333 (1890) (upholding an antiMormon oath requirement for voting).

327 Ellsworth, $A$ Landholder VII, in I4 THE Documentary History of THE Ratification of THE Constitution 448, 449 (J. Kaminski \& G. Saladino eds. 1983) (originally published 
The significance of the "oath or affirmation" provisions is more subtle. Oaths of office were serious matters, so serious that the President's oath of office is spelled out in the otherwise spare text of article II. Moreover, the I787 Constitution requires that state as well as federal officers be "bound by Oath or Affirmation, to support this Constitution" - one of the few provisions of the Constitution directed at state officers. Yet the framers of the Constitution realized that several small religious sects, including the influential Quakers, refused to swear oaths, on authority of Matthew 5:33-37. Lest members of these sects be excluded from office, it was necessary to provide alternatives.

As has already been noted, this problem had arisen in most of the states in connection with the oaths required of witnesses in court, as well as with oaths of office. ${ }^{328}$ The usual solution was to create an exemption only for those with the religious objection and to require all others to take the oath. The framers of the federal Constitution, however, did not follow this model; they allowed any person, whether "conscientiously scrupulous" or not, to promise by affirmation instead of oath. Perhaps this was an act of verbal economy. Perhaps it reflected a principled objection to exemptions limited to those of particular beliefs. In any event, the framers solved the oath problem without the need for a free exercise exemption.

The new Constitution made no other provision for religious differences. Indeed, it appears the subject did not come up, though Luther Martin (not always the most reliable of sources) stated that he was "positive" that "[a]n honorable member from South Carolina" made an "attempt to have a stipulation in favour of liberty of conscience, but in vain." 329 The prevailing view among the Federalists, the supporters of the new Constitution, was that additional guarantees of individual liberty were unnecessary. Explicit guarantees might even be counterproductive, since the express mention of some liberties might be taken to disparage the existence of other rights, which were

in the Connecticut Courant, Dec. 17, I787). Oddly, Ellsworth supported a strict religious test for office in his own state. See M. BoRDEN, supra note 75 , at 18 .

328 See supra pp. $1467-68$.

329 Martin, Reply to The Landholder (Mar. I9, 1788), reprinted in 3 FARRAND RECoRdS, supra note 160 , at 286, 290. Martin was probably recalling Charles Pinckney's several efforts to ban religious tests for office. A less likely possibility is that Martin recalled Pinckney's original draft of a constitution, which may have provided: "The Legislature of the United States shall pass no Law on the subject of Religion." The Pinckney Plan, reprinted in 3 Farrand Records, supra note 160 , at 595, 599. This draft (if it existed) was never debated, and the Committee of Detail included no such provision in the drafts it presented to the Convention. See 3 Farrand RECORDS, supra note 160 , at 595. According to Farrand, "it is established beyond all doubt" that the draft containing this language was not at all similar to the original Pinckney plan. See id. at 603; Jameson, Studies in the History of the Federal Convention of 1787 , I ANN. REP. AM. HIST. A. 89, III-32 (IgO2). 
adequately secured through the careful enumeration and delimitation of federal powers. ${ }^{330}$

Other participants in the debate were less trustful of the novel and distant federal government. Patrick Henry complained that a toopowerful federal government could override religious freedoms that had been hard won at the state level. 331 "Philadelphiensis," a Pennsylvania pamphleteer, objected to the transfer of control over military service to the federal government for fear that the Quakers would lose the exemptions from compulsory service they had won at the state level: "Their influence in the state of Pennsylvania is fully sufficient to save them from suffering very materially on this account; but in the great vortex of the whole continent it can have no weight." "332 The leader of the Virginia Baptists, John Leland, opposed ratification on the ground that religious freedom was "not sufficiently secured."333 "[]]f Oppression dose not ensue," he wrote, "it will be owing to the Mildness of administration \& not to any Constitutional defence." 334 In the Rhode Island town meetings of $1788-89$, citizens spoke out against the lack of protection for liberty of conscience "and other fundamental liberties," and the state refused to ratify the Constitution until after the Bill of Rights had been proposed.335 Others, perhaps more numerous, supported ratification but demanded amendments incorporating a bill of rights. These advocates were sufficiently persuasive (or sufficiently numerous) to extract the promise of a Bill of Rights as the price for ratification of the rest of the Constitution.

Perhaps the most significant political battleground for future development of a strong protection for religious freedom was in the foothills of Virginia, where the young James Madison, recently returned from the Constitutional Convention, was seeking a seat in the first House of Representatives. Like other proponents of the Consti-

330 See, e.g., I ANNALS OF CONG. 456 (J. Gales ed. 1834) (statement of James Madison, June 8, I789); The Federalist No. 84, at 5 ro (A. Hamilton) (C. Rossiter ed. I961).

331 See 3 Elliot's Debates, supra note 165 , at 317-18 (June 12, 1788).

${ }_{332} 3$ The COMPLETE ANTI-FEDERALIST $\$ 3.9 .12$, at I07 (H. Storing ed. I98I). A similar argument was made by another pamphleteer nicknamed "An Old Whig." See id. $\S 3.3 .29$, at 36.

3334 Documentary History of the Constitution of the United States of AMERica 528 (U.S. Dep't of State ed. I905) [hereinafter DocumentaRy History of ThE Constirution]. The Virginia Baptist Association voted unanimously to oppose ratification, a fact that several men quickly communicated to Madison, with the request that he take steps to mollify them. See R. Semple, A History of the Rise and Progress of the Baptists in Virginia 99 (Richmond I8ro); Letter from James Madison, Sr., to James Madison (Jan. 30, 1788), in 5 THE WRITINGS OF JAMES Madison, supre note ro9, at ro5 n.r; Letter from Joseph Spencer to James Madison (Feb. 28, 1788), in 4 Documentary History of the Constitution, supra, at 525.

3344 Documentary History of the Constitution, supra note 333 , at 528.

335 See C. AntieaU, A. Downey \& E. Roberts, supra note 16, at 152-53; F. Bates, RHODE ISLAND AND THE FORMATION OF THE UNION $165-76$ (I898). 
tution of 1787 , Madison initially lacked enthusiasm for adding a Bill of Rights, though he came to recognize the need for one to assuage the demands of the Antifederalist opposition. In a letter to Washington, he called "several of" Virginia's proposed amendments "highly objectionable." 336 But when he initiated his candidacy for Congress, he discovered that his Baptist constituents were prepared to throw their support to his opponent, James Monroe. On advice of his political adviser, George Nicholas, ${ }^{337}$ Madison contacted Baptist leaders and proclaimed his support for "the most satisfactory provisions for all essential rights, particularly the rights of Conscience in the fullest latitude." 338 He then championed a constitutional provision for religious liberty as a campaign issue. ${ }^{339}$ The Baptist leaders responded by giving him their electoral support, which contributed to his narrow margin of victory. A letter to Madison contains an interesting eyewitness account of a gathering at the Blue Run Baptist Church, at which the minister, the Reverend George Eve, "took a very Spirited and decided Part in your favour" and "Spoke Long" on the subject of Madison's contributions to religious freedom. ${ }^{340}$

There were two strands to the Federalist argument against a free exercise amendment. First, under the Constitution, the new federal government was not given any powers to pass laws affecting religion. As Madison told the Virginia ratifying convention, "There is not a shadow of right in the general government to intermeddle with religion. Its least interference with it would be a most flagrant usurpation." 341 Proponents of a free exercise amendment understandably

336 See Letter from James Madison to George Washington (June 27, I788), in II MadisoN PAPERS, supra note 226, at I82; see also Letter from James Madison to Thomas Jefferson (Oct. I7, I788), in 5 The Writings OF JAMEs MADISON, supra note I09, at 271 (stating that Madison had never viewed the Bill of Rights "in an important light").

337 See Letter from George Nicholas to James Madison (Jan. 2, 1789), in Ir MADISON PAPERS, supra note 226, at 406 .

338 Letter from James Madison to the Rev. George Eve (Jan. 2, I789), in II MaDISON PAPERS, supra note 226, at 404, 405; see also Letter from James Madison to Thomas M. Randolph (Jan. I3, I789), in II MADISON PAPERS, supra note 226, at 415, 416.

${ }^{339}$ See Letter from James Madison published in the Fredricksburg (Va.) Herald (Jan. 29, I789), in II MADISON PAPERS, supra note 226, at 428 (promising to sponsor a constitutional amendment); Letter from James Madison to George Washington (Jan. 14, I789), in Ir MadisoN PAPERS, supra note 226, at 4I7 (describing his speeches and newspaper campaign to dispel a report that he opposed constitutional amendments); see also Letter from David Jameson, Jr., to James Madison, in II MAdison PAPERS, supra note 226, at 4I9 (Jan. 14, I789) (thanking Madison for making an address in Culpepper County on the issue of amendments).

${ }^{340}$ Letter from Benjamin Johnson to James Madison (Jan. 19, I789), in II MADISON PAPERS, supra note 226 , at 423,424 .

3413 Elliot's Debates, supra note 165 , at 330 (June 12, 1788). James Iredell made a similar argument in the North Carolina ratifying convention. See 4 id. at I94 (July 30, 1788). Roger Sherman of Connecticut continued to make the argument in the First Congress in 
rejected this argument. The federal government would exercise plenary regulatory authority in the territories, ${ }^{342}$ the District of Columbia, ${ }^{343}$ and the military. ${ }^{344}$ Its powers of taxation, ${ }^{345}$ spending, ${ }^{346}$ immigration and naturalization, ${ }^{347}$ copyright, ${ }^{348}$ international trade, ${ }^{349}$ bankruptcy, ${ }^{350}$ and relations with Indian tribes ${ }^{351}$ and foreign governments $^{352}$ could, with little imagination, be expected to affect the exercise of religion. The potential of the necessary and proper clause might be viewed - and was viewed, according to Madison as the most threatening of all. ${ }^{353}$ Thus, a federal government bent

opposition to enactment of the religion clauses. See I ANNaLs of Cong. 757 (J. Gales ed. 1834) (statement of Roger Sherman, Aug. 15, 1789).

${ }_{342}$ See Reynolds v. United States, 98 U.S. 145 (1878) (upholding the petitioner's conviction under territorial legislation outlawing the Mormon practice of polygamy).

343 See H. Rep., Returned Bill 2 I (Feb. 23, 1811), reprinted in 5 The Founders' ConstITUTion, supra note 72, at 99 (recording President Madison's veto of "An Act incorporating the Protestant Episcopal Church in the town of Alexandria, in the District of Columbia," on the ground that Congress' authority over the District of Columbia should not be used to define the functions and governance of a church).

344 See Goldman v. Weinberger, 475 U.S. 503 (1986) (upholding an Air Force uniform regulation prohibiting the wearing of a yarmulke).

345 See Hernandez v. Commissioner, rog S. Ct. 2136 (r989) (rejecting a claim that disallowance of claimed charitable contributions violated the religion clauses).

346 See Flast v. Cohen, 392 U.S. 83 (1968) (holding that federal taxpayers who alleged that the appropriation of federal funds to religious schools violated the establishment and free exercise clauses had standing to sue).

347 See Girouard v. United States, 328 U.S. 6I (1946) (holding that the Nationality Act did not require Seventh-day Adventist aliens to swear to bear arms in defense of the country); United States v. Aguilar, 87 I F.2d I436 (9th Cir. 1989) (sustaining the conviction of defendants engaged in a sanctuary movement who challenged enforcement of immigration laws as violative of their free exercise rights).

348 See United Christian Scientists v. Christian Science Bd. of Directors, 829 F.2d I152 (D.C. Cir. 1987) (holding that congressional extension of the Christian Science Church's copyright on all Christian Science scripture unconstitutionally contravened the first amendment rights of a dissident group that wished to publish a variant).

349 See I9 U.S.C. $\S \mathrm{I} 202$, sch. 8, pt. 4, I 850 (I988) (exempting certain religious artifacts from import duties).

350 See In re Reynolds, 83 Bankr. 684 (W.D. Mo. 1988) (regulating the religious contributions of a debtor in bankruptcy).

351 See Quick Bear v. Leupp, 2ro U.S. 50 (1908) (maintaining that prohibiting the exercise of Indian treaty power to appropriate tribal and trust funds for sectarian education would deny an Indian's free exercise of religion).

352 See Americans United for Separation of Church \& State v. Reagan, 786 F.2d 194 (3d Cir.) (upholding denial of standing to a group raising an establishment clause challenge to the appointment of an ambassador to the Vatican), cert. denied, 479 U.S. 914 (1986).

353 See I ANNALs of Cong. 758 (J. Gales ed. 1834) (speech by James Madison, Aug. I5, 1789). Madison observed:

[S]ome of the State Conventions ... seemed to entertain an opinion that under the clause of the constitution, which gave power to Congress to make all laws necessary and proper to carry into execution the constitution, and the laws made under it, enabled them to make laws of such a nature as might infringe the rights of conscience, and establish a national religion. 
on religious oppression could accomplish such oppression under pretext of one of the enumerated powers. Moreover, the argument that the lack of enumerated power could serve as a sufficient assurance of religious liberty offered no comfort to those who understood free exercise of religion to entail exemption from otherwise legitimate general legislation. Such legislation is by definition within the enumerated powers of the federal government.

The second strand of the Federalist argument was more persuasive. The Federalists argued that the structure of government, combined with the multiplicity of religious sects, would provide an effective guarantee against religious oppression. Madison's defense of the Constitution in the Virginia convention typified this position:

Religion is not guarded; there is no bill of rights declaring that religion should be secure .... Happily for the states, they enjoy the utmost freedom of religion. This freedom arises from that multiplicity of sects which pervades America, and which is the best and only security for religious liberty in any society; for where there is such a variety of sects, there cannot be a majority of any one sect to oppress and persecute the rest. 354

This argument exactly parallels Madison's famous defense of the Constitutional structure in Federalist No. 5I. There he says that the "security for civil rights must be the same as that for religious rights. It consists in the one case in the multiplicity of interests, and in the other in the multiplicity of sects." 355 The best cure for factional oppression is a large republic with many conflicting factions and a representative government with checks and balances. ${ }^{356}$

3543 Elliot's Debates, supra note 165 , at 330 (June I2, 1788).

355 The Federalist No. 5I, at 324 (J. Madison) (C. Rossiter ed. I96I). See also id. No. Io, at 79 (J. Madison) (citing "[a] zeal for different opinions concerning religion" as his first example of a "faction").

356 Madison's theory of religious faction was no doubt a product of his experiences during the assessment controversy in Virginia, where the two largest denominations - Anglican and Presbyterian - were played off against one another. It also had roots in European thought. Madison was fond of quoting Voltaire that "[i]f one religion only were allowed in England, . . . the government would possibly become arbitrary; if there were but two, the people would cut each other's throats; but, as there are such a multitude, they all live happy and in peace." W. RIves, 2 History OF THE LIFE AND Times OF JAMES Madison 220 n.I (I866) (quoting F. Voltaire, LetTres SUR LeS ANGlais). Similarly, Adam Smith, in The Wealth of Nations, observed:

The interested and active zeal of religious teachers can be dangerous and troublesome only where there is, either but one sect tolerated in the society, or where the whole of a large society is divided into two or three great sects; the teachers of each acting by concert, and under a regular discipline and subordination. But that zeal must be altogether innocent where the society is divided into two or three hundred, or perhaps into as many thousand small sects, of which no one could be considerable enough to disturb the public tranquillity.

A. SMITH, supra note 156 , bk. 5 , ch. 1 , pt. 3 , art. 3 , at 745 . 
If the principal danger to religious liberty was the deliberate oppression of religious minorities by the majority, then the Madisonian vision offered a more powerful answer to those demanding a free exercise clause. In a nation of many different religious groups, each jealous of the others, it would be difficult if not impossible for any group to impose its beliefs on the others. Yet Madison's argument did not carry the day. Perhaps the reason is that his argument did not satisfy the concerns of those, like the Quakers addressed by "Philadelphiensis," who feared not deliberate oppression, but the unintended effects of legislation passed without regard to the religious scruples of small minorities. The multiplicity of sects provides no protection against ignorance or indifference. Indeed, the position of religious minorities might be made much worse. Because settlements of minorities tend to be concentrated in particular regions, most sects had greater influence at the state level than in "the great vortex of the whole continent."357 The same extended Union that protected minority faiths against oppression would make them more vulnerable to thoughtless general legislation.

Federalist assurances thus failed to assuage the concerns of America's religious sects, including many of Madison's own constituents. Only a bill of rights would do.

\section{B. Framing and Ratifying the Free Exercise Clause}

r. Debates in the First Congress. - Madison admitted that the lack of a provision protecting the rights of conscience had "alarmed many respectable Citizens," and he pledged to work for "the most satisfactory provisions for all essential rights, particularly the rights of Conscience in the fullest latitude, the freedom of the press, trials by jury, security against general warrants \&c."358 Lawmakers in other states responded to the same popular pressure. Seven states drafted proposals for amendments, and five of them (plus the minority report in Pennsylvania) urged protection for religious freedom. New York, for example, ratified the Constitution but proposed a bill of rights including the following provision: "That the people have an equal, natural, and unalienable right freely and peaceably to exercise their religion, according to the dictates of conscience ...."359 Virginia proposed a similar provision, using the phrase "free exercise of reli-

3573 The CoMplete ANTI-FEderalist, supra note 332 , $\$ 3.9 .12$, at 107.

358 Letter from James Madison to the Rev. George Eve (Jan. 2, 1789), in 11 Madison PAPERS, supra note 226, at 404, 404-05. Madison subsequently published this promise in the Fredericksburg Herald. See Letter from James Madison published in the Fredericksburg (Va.) Herald (Jan. 29, 1789), in II MADison PAPERS, supra note 226, at 428 .

359 I ELLIOT'S DEBATES, supra note 165 , at 327 (July 26, I788). 
gion"; 360 Rhode Island ${ }^{361}$ and North Carolina ${ }^{362}$ made proposals virtually identical to Virginia's.

Only New Hampshire, of the states that proposed a federal bill of rights, used a markedly different formulation: "Congress shall make no laws touching religion, or to infringe the rights of conscience."363 The wording of this proposal tends to support the exemptions view, since the second clause would have little, if any, application unless secular, generally applicable laws (laws not "touching religion") could violate the rights of conscience. This proposal was considered on the floor of the House of Representatives, briefly adopted, and then rejected in favor of a formulation similar to today's free exercise clause. 364

The recorded debates in the House over these proposals cast little light on the meaning of the free exercise clause. Indeed, the main controversy during these debates centered on establishment. The key changes in free exercise language ("free exercise of religion" in place of "equal rights of conscience," and "prohibiting" in place of "infring[ing]") took place after the recorded debate. Thus, we must rely primarily on the successive drafts of the clause during its passage through the First Congress.

Madison undertook an initial draft of the Bill of Rights, to be proposed to the House of Representatives. His draft free exercise clause did not follow the language of the state proposals. Rather, he suggested the following formulation: "The civil rights of none shall be abridged on account of religious belief or worship, [n]or shall any national religion be established, nor shall the full and equal rights of conscience be in any manner, nor on any pretext, infringed."365 Three aspects of the Madison proposal are suggestive. First, the formulation "full and equal rights of conscience" implies that the liberty has both a substantive and an equality component: the rights must be both "full" and "equal." Hence, the liberty of conscience is entitled not only to equal protection, but also to some absolute measure of protection apart from mere governmental neutrality.

360 The Virginia proposal read:

That religion, or the duty which we owe to our Creator, and the manner of discharging it, can be directed only by reason and conviction, not by force or violence; and therefore all men have an equal, natural, and unalienable right to the free exercise of religion, according to the dictates of conscience . . . .

3 id. at 659 (June 27,5788 ). The Virginia proposal was taken almost verbatim from the Virginia Bill of Rights of 1776 . See supra text accompanying note $25 \mathrm{r}$.

361 See I Elliot's Debates, supra note 165, at 334 (May 29, I790).

362 See 4 id. at 244 (Aug. I, I788).

$363 \mathrm{I}$ id. at 326 (June $2 \mathrm{I}, \mathrm{I788}$ ).

364 See I ANnals of Cong. 757-59 (J. Gales ed. I834) (Aug. I5, I789), 796 (Aug. 20, I789).

${ }^{365}$ Id. at $45 \mathrm{I}$ (proposal of James Madison, June 8, I789). 
Second, the formulation that the rights in question shall not "in any manner nor on any pretext" be infringed suggests protection from infringements in any form, even those not expressly directed at religious practice. This proposal recognized that infringements on rights of conscience could result from Congress' exercise of its enumerated powers even when the legislation made no direct reference to religion. For the most part these infringements would be indirect - secular laws that invaded religious freedom as applied, rather than acts directed toward religious practice or belief as such.

Third, Madison favored the formulation "rights of conscience" over the formulation "free exercise of religion," which was found both in his own state's laws and in three of the five state proposals. This choice of language was ultimately reversed after deliberation by the House and the Senate; its meaning is considered below. ${ }^{366}$

Rather than debating Madison's proposal, the Select Committee proposed a much shorter version: "no religion shall be established by law, nor shall the equal rights of conscience be infringed."367 The Committee deleted Madison's reference to "Civil Rights," probably because it was redundant, and shortened his "full and equal rights of conscience" to "equal rights of conscience." If this change was more than stylistic, which seems doubtful, it might suggest a move toward a no-exemptions view of free exercise, since it emphasizes equal treatment rather than full substantive protection.

The Select Committee language ran into trouble in the House, largely because of concerns that its establishment provision might interfere with the ability of the states to support religion - an issue especially important to those states with established churches. After a brief flirtation with the New Hampshire language, previously discussed, 368 the House adopted a formulation proposed by Fisher Ames of Massachusetts: "Congress shall make no law establishing religion, or to prevent the free exercise thereof, or to infringe the rights of conscience."369 This version omitted the modifiers "full" and "equal" from the phrase "rights of conscience." This suggests that the deletion of "full" by the Committee was no more than stylistic and that the word "equal" was deleted so as not to create a negative inference.

More strikingly, the Ames version introduced a new term into the debate: "free exercise of religion." "Free exercise" had been part of most of the state proposals but had not appeared in the Madison, Select Committee, or New Hampshire proposals previously debated in the House, all of which had used the alternative formulation "rights of conscience." In many contexts, the phrases "rights of conscience"

366 See infra pp. 1488-1500.

367 I ANNALS of CoNg. 757 (J. Gales ed. 1834) (Aug. I5, 1789).

368 See supra text accompanying notes $363-364$.

369 I ANNAls of Cong. 796 (J. Gales ed. 1834) (proposal of Fisher Ames, Aug. 20, 1789). 
and "free exercise of religion" seem to have been used interchangeably. But here, Ames, a notoriously careful draftsman and meticulous lawyer, thought it necessary to use both terms. The significance of this change will be considered below. ${ }^{370}$

The House of Representatives approved the amendment as proposed by Ames without recorded debate or discussion. Both the House and the Senate journals record that the House passed and sent to the Senate a proposed amendment slightly different from the Ames proposal: "Congress shall make no law establishing Religion, or prohibiting the free exercise thereof, nor shall the rights of conscience be infringed." 371 The difference between these two versions is a shift in verbs from "prevent" to "prohibit" and a shift in grammatical form from infinitives to gerunds. Whether these changes result from an unrecorded amendment or from mistranscription in either the Annals or the final copy of the engrossed bill is unknown. ${ }^{372}$

Whatever the precise chain of events, the language considered by the Senate and ultimately employed in the first amendment was "prohibiting the free exercise [of religion]." This wording has proven significant to the Supreme Court's interpretation of the free exercise clause and is discussed in detail below. ${ }^{373}$

In the Senate, the debate was not recorded, but various versions of the religion clauses were adopted and rejected in succession. The versions adopted, in order, were as follows:

(I) "Congress shall make no law establishing one religious sect or society in preference to others, nor shall the rights of conscience be infringed." 374

(2) "Congress shall make no law establishing religion, or prohibiting the free exercise thereof." 375

${ }^{370}$ See infra pp. $1488-1500$.

371 I DOCUMENTARy History of the First FEderal Congress of the UNited States of America 136 (L. De Pauw ed. I972) (Senate Journal); 3 id. at 159 (House Journal) [hereinafter DOCUMENTARY HISTORY].

372 See Laycock, supra note 16, at 879 n.27. The Annals is not entirely reliable. See id. at 885. For a glaring example, see I ANNALS of CoNG. 948 (J. Gales ed. I834) (Sept. 24, 1789) (transcribing the final version of the free exercise clause adopted by both Houses as ". . . or prohibiting $a$ free exercise thereof" (emphasis added)). Madison wrote that the reporter's notes, later printed in the Annals, showed "the strongest evidences of mutilation \& perversion, and of the illiteracy of the Editor." Tinling, Thomas Lloyd's Reports of the First Federal Congress, i 8 WM. \& MARY Q. 519, 532-33 (3d ser. I96I) (quoting PAPERS OF JAMES MAdISON XI, No. 58, Lib. Congress). See generally Hutson, The Creation of the Constitution: The Integrity of the Documentary Record, 65 TEX. L. REv. I (1986) (arguing that most records of the drafting and ratification of the Constitution may be seriously unreliable).

373 See infra pp. 1486-88.

374 I DOCUMENTARY HISTORY, supra note $37 \mathrm{I}$, at $15 \mathrm{I}$ (Senate Journal).

375 Id. 
(3) "Congress shall make no law establishing articles of faith or a mode of worship, or prohibiting the free exercise of religion . . ."376

Note that each of these versions used either the phrase "rights of conscience" or the phrase "free exercise of religion." No version used the phrases in conjunction, as had the Ames proposal.

The third version passed the Senate and was transmitted to the House, which rejected it, presumably because of its narrow provision on establishment. A Conference Committee, on which Madison served, proposed the version of the religion clauses that was ultimately ratified. ${ }^{377}$ The free exercise clause itself was unchanged from the final Senate bill.

One final point about the debate in the First Congress deserves mention. In addition to the provision already discussed, which applied only to the federal government, Madison proposed an amendment that would have been applicable to the states. It read: "[N]o State shall infringe the equal rights of conscience, nor the freedom of speech or of the press, nor of the right of trial by jury in criminal cases."378 Madison said that he conceived this to be "the most valuable amendment in the whole list. If there were any reason to restrain the Government of the United States from infringing upon these essential rights, it was equally necessary that they should be secured against the State Governments."379 Significantly, Madison did not propose that the establishment clause be made applicable to the states; this reflects the prevailing view at the time that states should be permitted to set their own course with respect to establishment, but that liberty of conscience was an unalienable right. With minor editorial change, the House adopted Madison's proposal. 380 Later the Senate rejected the proposal, presumably in deference to states' rights. ${ }^{381}$ This left the provisions of the Bill of Rights solely as limitations against the federal government, ${ }^{382}$ as they were to remain

376 Id. at I66 (Senate Journal).

377 See 3 id. at 228 (House Journal).

378 I ANNALS OF Cong. 783 (J. Gales 1834) (Aug. I7, 1789).

379 Id.

380 See id. at 784 .

381 No less a Federalist than James Iredell had commented in his state's ratifying convention:

It has been asked . . . why a guaranty of religious freedom was not included. . . . Had

Congress undertaken to guaranty religious freedom, or any particular species of it, they would then have had a pretence to interfere in a subject they have nothing to do with.

Each state, so far as the [republican form of government clause] does not interfere, must

be left to the operation of its own principles.

4 Elliot's Debates, supra note 165 , at $194-95$ (July 30, 1788 ) (emphasis in original).

382 See Permoli v. Municipality No. I, 44 U.S. (3 How.) 588, 609 (1845) ("The Constitution makes no provision for protecting the citizens of the respective States in their religious liberties; this is left to the State constitutions and laws."). 
until the Supreme Court held that they had been selectively "incorporated" pursuant to the fourteenth amendment. ${ }^{383}$

Any interpretation of the religion clauses as applying to the states is thus somewhat anachronistic. Because the free exercise clause at the federal level was itself modeled on free exercise provisions in the various state constitutions, however, no structural distortions arise from assuming that, for modern purposes (after "incorporation"), the free exercise clause means the same thing for states that it has always meant for the federal government. ${ }^{384}$

2. Ratification. - The ratification debates in the state legislatures were unilluminating. Most states ratified the proposed amendments quickly, with little debate or controversy. Three states - Georgia, Massachusetts, and Connecticut - failed to ratify, but the refusal seems to have been unrelated to questions of religious freedom. Only in Virginia is there record of opposition to the religion clauses as proposed by Congress. In Virginia, the Senate delayed ratification of the first amendment, partly on the ground that it "does not prohibit the rights of conscience from being violated or infringed." 385 The reasons for this are difficult to fathom, since neither Virginia's own Bill of Rights nor the amendment on religious freedom the state proposed to the Congress contained a separate "rights of conscience" clause, and in the only legal document in which the "rights of conscience" and the "exercise of religion" were differentiated - the Georgia Charter of $\mathrm{I} 73^{386}$ - free exercise was broader than the rights of conscience. ${ }^{387}$ Historian Leonard Levy attributes the delay to Antifederalist political maneuvering rather than to serious substantive opposition to the language of the first amendment. ${ }^{388}$ After two years, the first amendment was ratified without additional comment.

3. Two Issues of Interpretation. - As has been noted, ${ }^{389}$ two key modifications in the language that ultimately became the free exercise clause were made after the close of recorded debate. In the House, the verb "prohibit" was substituted for the broader term "infringe."

${ }^{383}$ See Cantwell v. Connecticut, 310 U.S. 296, 303 (1940) (applying the free exercise clause to the states for the first time through the fourteenth amendment).

384 Incorporation of the establishment clause presents far more serious interpretive difficulties, since there existed no national consensus on the question of governmental aid to religion, other than to leave the question to the states; in addition, the ramifications of establishment are different for small than for large units of government.

385 C. ANTIEAU, A. Downey \& E. RoBerts, supra note 16 , at 145 (quoting Journal of THE SENATE of VIRGINIA FOR 1789 , at 5I (available at Virginia State Library, Richmond)).

386 See Ga. Charter of 1732 , reprinted in I Federal and State Constitutions, supra note 2 , at 369 .

${ }^{387}$ See infra pp. r489-9o.

388 See L. LEVX, supra note 16 , at 86-89.

389 See supra p. I48I. 
In the Senate, the term "free exercise of religion" was adopted and the term "rights of conscience" was deleted. Both changes could have important implications for the meaning of the free exercise clause. But since there was no recorded debate or discussion of these later versions, we can only rely on context, contemporary diction, and other indirect evidence of meaning.

(a) The Meaning of "Prohibiting." - The prior drafts considered by the House used the verbs "infringing" or "preventing" to describe the forbidden effect on the rights of conscience. Moreover, in parallel clauses of the first amendment, the framers used the verb "abridging" to protect the freedoms of speech, assembly, and petition. The Supreme Court later relied on this choice of words to support a restrictive reading of the free exercise clause. In Lyng $v$. Northwest Indian Cemetery Protective Association, ${ }^{390}$ the Court reasoned: "The crucial word in the constitutional text is 'prohibit"; therefore, the free exercise clause does not require the government "to bring forward a compelling justification" for actions "which may make it more difficult to practice certain religions but which have no tendency to coerce individuals into acting contrary to their religious beliefs." 391 This textual argument is further developed in the Department of Justice study of the origins of the free exercise clause: "[P]rohibiting' and 'abridging' are denotatively and connotatively distinct. 'Prohibiting' means to forbid or prevent, while 'abridging' means to reduce or limit. Thus, 'prohibiting' connotes a finality, certitude, or damning not present in 'abridging,' which connotes limitations falling short of the finality of prohibition or prevention." 392 On the strength of this textual evidence alone, the report concludes that laws that discourage or inhibit religious exercise by denying government benefits (even those enacted in "purposeful discrimination" against a religion) do not violate the free exercise clause. ${ }^{393}$ Only laws that make a religious practice unlawful or impossible are forbidden.

While contemporaneous definitions of "prohibit" indicate that it was a stronger and narrower term than "abridge" or "infringe," the distinction is probably overdrawn in the context of the free exercise debate in I789. Among the synonyms for "prohibit" listed in Samuel Johnson's I755 edition is "to hinder,"394 which seems weaker and broader than "abridge" or "infringe." Since the verb form used for the establishment clause ("respecting") was different from the verb form used for the free speech clause ("abridging"), it seems more likely

\footnotetext{
390485 U.S. 439 (I 988$)$.

391 Id. at 451 .

392 REPORT TO THE ATTORNEY GENERAL, supra note 17 , at 17 (citing various dictionaries, including a I755 edition of Samuel Johnson's and an I828 edition of Noah Webster's).

393 See id. at 47 n.84.

394 2 S. Johnson, A Dictionary of The ENglish Language, supra note 268.
} 
that the drafters found it less awkward or more euphonious to use yet a third verb form ("prohibiting") for the free exercise clause. 395 No one in the debate, in or out of Congress, expressed the view that infringements that are not final, certain, or "damning" 396 should be allowed. Madison had promised to support "the most satisfactory provisions for all essential rights, particularly the rights of Conscience in the fullest latitude," 397 and Daniel Carroll, a Roman Catholic from Maryland, had stated that the "rights of conscience . . . will little bear the gentlest touch of governmental hand" and that "many sects have concurred in opinion that they are not well secured under the present constitution." 398 If the final version had been understood to allow infringements short of outright prohibition, one of these gentlemen would surely have spoken up. But both seemed satisfied with the bill's language, as did their constituents. A Baptist leader wrote Madison to tell him "that the amendments had entirely satisfied the disaffected of his Sect."399

Ten years after the House debate, Madison commented on the difference in verbs in the three portions of the first amendment (laws respecting Establishment, laws prohibiting free exercise, and laws abridging the freedom of speech, press, or assembly). The argument had been made (by no less a figure than John Marshall) that Congress had greater power over the press than over the establishment of religion, because the term "abridging" was less encompassing than the term "respecting." 400 Madison, in response, stated that "the liberty of conscience and the freedom of the press were equally and completely

395 The word choice may therefore reflect what is called "elegant variation," disapproved of by modern authorities. See H. Fowler, A Dictionary OF MODERN ENGLish USAGE 130-33 (1927).

396 See REPORT to THE ATtORNEy General, supra 17 , at 17.

397 Letter from James Madison to the Rev. George Eve (Jan. 2, 1789), in I I Madison PAPERS, supra note 226, at $404,405$.

398 I ANNALS of CoNG. 757-58 (J. Gales ed. 1834) (Aug. 15, 1789).

399 Letter from James Madison to George Washington (Nov. 20, 1789), in 5 The Writings OF JAMES MADison, supra note rog, at 429 .

400 See Marshall, Report of the Minority on the Virginia Resolutions (Jan. 22, I799), reprinted in 5 THE FOUNDERS' CONSTITUTION, supra note 72, at 136 , 138 . Marshall's argument, in full, was as follows:

In a solemn instrument, as is a constitution, words are well weighed and considered before they are adopted. A remarkable diversity of expression is not used, unless it be designed to manifest a difference of intention. Congress is prohibited from making any law RESPECTING a religious establishment, but not from making any law RESPECTING the press. When the power of Congress relative to the press is to be limited, the word RESPECTING is dropt, and Congress is only restrained from the passing any law ABRIDGING its liberty. This difference of expression with respect to religion and the press, manifests a difference of intention with respect to the power of the national legislature over those subjects, both in the person who drew, and in those who adopted this amendment.

Id. 
exempted from all authority whatever of the United States."401 He went on to argue:

[I]f Congress may regulate the freedom of the press, provided they do not abridge it, because it is said only "they shall not abridge it," and is not said "they shall make no law respecting it," the analogy of reasoning is conclusive that Congress may regulate and even abridge the free exercise of religion, provided they do not prohibit it; because it is said only "they shall not prohibit it," and is not said "they shall make no law respecting, or no law abridging it." 402

Madison found this interpretation of the free exercise clause so absurd that to state it was to refute it. Despite its plausibility as a textual matter, the narrow interpretation of "prohibiting" should therefore be rejected, and the term should be read as meaning approximately the same as "infringing" or "abridging."

(b) The Substitution of "Free Exercise of Religion" for the "Rights of Conscience." - As noted above, ${ }^{403}$ the states requesting constitutional protection for religious freedom, with one exception, employed the language free "exercise" of "religion," borrowing from the Virginia Bill of Rights. Madison, for reasons that remain mysterious, did not follow this lead in his draft, using instead the term "rights of conscience," a term also used by the Select Committee and New Hampshire drafts debated on the floor of the House of Representatives. The term "free exercise of religion" reappeared after the close of recorded debate, in the Ames version, which protected both "free exercise of religion" and the "rights of conscience," and which passed the House. The Senate first voted to protect "rights of conscience" and then settled upon protecting the "free exercise of religion" alone, a formulation that ultimately carried the day. It is possible that these changes in language were without substantive meaning, for in many of the debates in the preconstitutional period, the concepts of "liberty of conscience" and "free exercise of religion" were used interchangeably. There are, nonetheless, three principal differences between the terms that may have significance for interpretation.

The least ambiguous difference is that the term "free exercise" makes clear that the clause protects religiously motivated conduct as well as belief. This point merits emphasis, because in I879 the Supreme Court, relying on Jefferson, explicitly rejected this reading. ${ }^{404}$ Only in 1940 did the Court begin to include religiously motivated conduct within the ambit of the free exercise clause, and even then,

401 Madison, Report on the Virginia Resolutions (Jan. 18, 1800), reprinted in 5 THE FOUNDERS' Constitution, supra note 72 , at 141,146 (emphasis in original).

402 Id.

${ }^{403}$ See supra pp. 1481-82.

404 See Reynolds v. United States, 98 U.S. 145, 164 (1879). 
only to a limited degree. ${ }^{405}$ The belief-action distinction is often used to suggest that protection for religiously motivated conduct is far weaker than that accorded to free speech or other, seemingly "absolute" freedoms. ${ }^{406}$

The choice of the words "free exercise of religion" in lieu of "rights of conscience" is therefore of utmost importance. As defined by dictionaries at the time of the framing, the word "exercise" strongly connoted action. The American edition of Samuel Johnson's Dictionary of the English Language, published in Philadelphia in I805, used the following terms to define "exercise": "Labour of the body," "Use; actual application of any thing," "Task; that which one is appointed to perform," and "Act of divine worship, whether public or private."407 Noah Webster's American dictionary defined "exercise" as "employment."408 James Buchanan's I757 dictionary defined "exercise" as "[t]o use or practice." 409 "Conscience" was more likely to have been understood as opinion or belief. Johnson equated "conscience" with the terms "knowledge," "Real sentiment; veracity; private thoughts," "Scruple; difficulty," and "reason; reasonableness." 110 Webster defined it as "natural knowledge, or the faculty that decides on the right or wrong of actions." 411 Buchanan defined it as the "testimony of one's own mind." $" 412$

The Georgia Charter of $I 732$ is the only legal document of the period to make a distinction between the two phrases. It provided "that there shall be a liberty of conscience allowed in the worship of God, to all persons inhabiting, or which shall inhabit or be resident within our said province, and that all such persons, except papists, shall have a free exercise of religion." 413 Since Roman Catholics were

405 See Cantwell v. Connecticut, 310 U.S. 296, 303-04 (1940).

406 See, e.g., McDaniel v. Paty, 435 U.S. 618, 626-27 (1978) (plurality opinion); Braunfeld v. Brown, 366 U.S. 599, 603-07 (196I); Walker v. Superior Court, 47 Cal. 3d II2, I39, 763 P.2d 852, 869, $253 \mathrm{Cal}$. Rptr. I, I8 (I988) (holding that the prosecution for manslaughter of a mother who refused any medical treatment except prayer for her son was not prohibited by the free exercise clause); Molko v. Holy Spirit Ass'n for the Unification of World Christianity, 46 Cal. 3d I092, III2, 762 P.2d 46, 56, 252 Cal. Rptr. I22, I32 (I988) (holding that the free exercise clause does not bar an action for fraud against a religious organization when that action implicates conduct, not belief); Madsen v. Erwin, 395 Mass. 715, 727-27, 48I N.E.2d 1 x60, II67 (1985) (holding that the free exercise clause would not prevent the consideration of tort claims arising out of the termination of a Christian Science Monitor employee who refused to seek healing through the church for her sexual preference).

407 S. JoHnson, supra note 252.

408 N. Webster, A Compendious Dictionary of the English Language (New Haven I806).

$409 \mathrm{~J}$. Buchanan, supra note $25 \mathrm{I}$.

$410 \mathrm{~S}$. JoHNSON, supra note 252.

$411 \mathrm{~N}$. WEBSTER, supra note 252.

$412 \mathrm{~J}$. BUChaNAN, supra note $25 \mathrm{I}$.

$413 \mathrm{Ga}$. Charter of 1732 , reprinted in I Federal and State Constitutions, supra note 2 , at 369,375 . 
guaranteed liberty of conscience but not the free exercise of religion, this suggests that the former was understood to be narrower than the latter. ${ }^{414}$ The most plausible reading of the provision is that it permitted Catholics to believe what they wished (and possibly to worship as they liked, though that is more doubtful), but did not permit them to put their faith into action. Such a policy would be consistent with the fears of the papacy that existed at the time.

By using the term "free exercise," the first amendment extended the broader freedom of action to all believers. As noted, the freedom of religion was almost universally understood (with Jefferson being the prominent exception) to include conduct as well as belief. 415 Accordingly, free exercise is more likely than mere liberty of conscience to generate conflicts with, and claims for exemption from, general laws and social mores.

A second important difference between the terms "conscience" and "religion" is that "conscience" emphasizes individual judgment,416 while "religion" also encompasses the corporate or institutional aspects of religious belief. In the great battle cry of the Protestant Reformation - "God alone is Lord of the conscience"417 - the individual conscience was used in contradistinction to the teaching of the institutional church. "Religion," by contrast, connotes a community of believers. The most widely accepted derivation of the word "religion" is from the Latin "religare" - to bind.418 Religion binds believers together; conscience refers to the inner faculty of judgment. Thus, the "free exercise of religion" suggests that the government may not interfere with the activities of religious bodies, even when the interference has no direct relation to a claim of conscience. ${ }^{419}$ This inter-

${ }^{414}$ It is not apparent what "liberty of conscience" included as applied to Catholics, or if the charter provision was enforced at all. During this period, Catholics were excluded from the colony, and those who entered were not permitted to receive land grants, inherit property, or hald public office. See R. STRICKLAND, supra note 62, at 80-81. Later, when governance of the colony was transfered from the Trustees to the Crown, the instructions to the royal governor denied even the liberty of conscience to Catholics and omitted any reference to "free exercise." See id. at I20.

415 For a discussion of the belief-action distinction prior to the framing, see pp. 1451-52 above.

416 See supra p. 1489 (quoting contemporaneous dictionary definitions of "conscience").

417 This statement was formally adopted as part of their creed by the Calvinists of Great Britain in I647. See The Westminster Confession of Faith, in 3 THE CREedS of Christendom 600 (P. Schaft $4^{\text {th }}$ ed. 1919). It presumably derived from John Calvin's Reply to Cardinal Sadolet, published in 1539, which stated: "There is nothing of Christ, then, in him who does not hold the elementary principle, that it is God alone who enlightens our minds to perceive his truth, who by his Spirit seals it on our hearts, and by his sure attestation to it confirms our conscience." J. Calvin, Reply to Letter by Cardinal Sadolet to the Senate and People of Geneva, in John Calvin: Selections FRom his Writings 81, 105 (J. Dillenberger ed. 1971).

418 See Random House DictionaRY of THE ENGLISH LANGUAGe 1628 (2d ed. 1987 ).

${ }^{419}$ An example would be the application of a nondiscrimination law to the employment of 
pretation is also consistent with the distinction drawn in the Georgia Charter, since the private devotions of individual Catholics would be of less concern to the state than the operations of an institutional Church with supposed connections to foreign powers.

The third, and most controversial, difference between the "free exercise of religion" and the "rights of conscience" is that the latter might seem to extend to claims of conscience based on something other than religion - to belief systems based on science, history, economics, political ideology, or secular moral philosophy. By deleting references to "conscience," the final version of the first amendment singles out religion for special treatment. And so the Supreme Court has held: "A way of life, however virtuous and admirable, may not be interposed as a barrier to reasonable state regulation . . . if it is based on purely secular considerations; to have the protection of the Religion Clauses, the claims must be rooted in religious belief."420

This distinction between religion and other belief systems has come under substantial attack in academic circles. ${ }^{421}$ Religion is understood

a minister. See, e.g., Rayburn v. General Conference of Seventh-Day Adventists, 772 F.2d II64 (4th Cir. I985), cert. denied, 478 U.S. IO20 (I986). Under the view of free exercise espoused in the text, such a law would be an unconstitutional interference in a religious function even if the religious group in question had no doctrinal tenet requiring or allowing discrimination.

420 Wisconsin v. Yoder, 406 U.S. 205, 215-16 (1972). This position was unanimously reaffirmed in Frazee v. Illinois Dep't of Employment Sec., rog S. Ct. I514, I5I7 (1989); see also Texas Monthly, Inc. v. Bullock, rog S. Ct. 890, gor n.8 (Ig8g) (plurality opinion) (Brennan, J.) (noting that exemptions conferred exclusively on religious groups or individuals on account of their religious convictions do not violate the establishment clause if they are "designed to alleviate government intrusions that might significantly deter adherents of a particular faith from conduct protected by the Free Exercise Clause"); Marsh v. Chambers, 463 U.S. 783, 812 (I983) (Brennan, J., dissenting) ("[I]n one important respect, the Constitution is not neutral on the subject of religion: Under the Free Exercise Clause, religiously motivated claims of conscience may give rise to constitutional rights that other strongly held beliefs do not." (emphasis in original)) .

The draft cases of the Vietnam War era marked the only instance in the Court's history that it extended religious exemptions to persons with essentially secular claims of conscience. See Welsh v. United States, 398 U.S. 333 (1970). Four members of the Court in Welsh rested their decision on (not very persuasive) statutory construction grounds. One member of the Court Justice Harlan - joined the majority on the ground that a distinction between religious and secular claims of conscience would be unconstitutional. See id. at 356 (Harlan, J., concurring).

Although the Supreme Court has consistently confined the constitutional protections of the free exercise clause to religion, it sometimes takes the opposite position with regard to accommodations not required under the free exercise clause. Compare Estate of Thornton v. Caldor, Inc., 472 U.S. 703, 7II (1985) (O'Connor, J., concurring) (finding a statute unconstitutional because it "singles out Sabbath observers for special . . . protection without according similar accommodation to ethical and religious beliefs and practices of other private employees") and Caldor, 472 U.S. at 7 Io n. 9 (same) with Corporation of the Presiding Bishop of the Church of Jesus Christ of Latter-Day Saints v. Amos, 483 U.S. 327, 338 (I987) ("Where . . government acts with the proper purpose of lifting a regulation that burdens the exercise of religion, we see no reason to require that the exemption come packaged with benefits to secular entities.").

421 See, e.g., R. DWorkin, TAKING RIghtS SERIOUSLY 200-OI (I977); M. Konvitz, RELIGIOUS LIBERTY AND CONSCIENCE 73-IO6 (1968); D. RICHARDS, supra note 54, at 136-46; Gamwell, Religion and Reason in American Politics, 2 J.L. \& RELIGION 325, 325-27 (I984). 
to be a product of individual choice, and protected as such. It is said to be arbitrary (and even unconstitutional) to differentiate between belief systems, all of which are the product of individual judgment, on the ground that some are "religious" and some are not.

David A.J. Richards has presented the most sustained and thoughtful exposition of this position. ${ }^{422}$ Professor Richards' conception of free exercise is rooted in liberal individualism. He views religious freedom as an aspect of the "equal respect" that must be shown "for the capacity to exercise our twin moral powers of rationality and reasonableness." 423 It is ultimately based on "respect for the person as an independent source of value."424 A definition of "conscience" sufficiently broad to encompass all that "neutrality requires" would "include[] everything and anything, including purely scientific beliefs about the causal structure of the world integrated into some larger rational and reasonable conception of one's ends."425 If the science of the origin and structure of the universe is included, so presumably must be the soft sciences of economics, politics, history, psychology, and the like. Richards thus contends that "the motivation for universal toleration must encompass all belief systems, religious and nonreligious, expressive of our moral powers of rationality and reasonableness." 426

Under this view, religious claims have no higher status than nonreligious claims - and maybe even lower status, to the extent that modern moral philosophy elevates "rationality and reasonableness" over the characteristic religious claims of revelation, tradition, and spirit-filled inspiration. And if the distinction between religious and nonreligious conscience is arbitrary, then it amounts to an indefensible preference - an establishment of religion - to accommodate religious and not nonreligious claims of comparable magnitude.

The question is therefore whether the principle of free exercise, as enacted by the framers and ratifiers of the first amendment, was a specific instantiation of a wicler liberty of conscience encompassing individual moral judgments rooted in nonreligious as well as religious sources, or whether religious conscience is different in some fundamental respect from other forms of individual judgment, in which case the free exercise clause would provide no warrant for protecting a broader class of claims. ${ }^{427}$ The question is all the more significant

422 See D. RICHARDS, supra note 54 , at $\mathrm{I}_{36-46}$.

423 Id. at 136.

424 Id. at 142 .

425 Id. at $14 \mathrm{I}-42$.

426 Id. at 138 .

${ }^{427}$ Professor Richards agrees that this issue must be resolved by reference to the "history and practice of religion clause jurisprudence," id. at I4I, but he devotes no attention to the actual history of the free exercise clause bearing on the specific point (nor to its "practice"). See 
for the practical reason that if the exercise of religion extends to "everything and anything," 428 the interference with ordinary operations of government would be so extreme that the free exercise clause would fall of its own weight. To protect everything is to protect nothing.

The historical materials uniformly equate "religion" with belief in God or in gods, ${ }^{429}$ though this can be extended without distortion to transcendent extrapersonal authorities not envisioned in traditionally theistic terms. ${ }^{430}$ By contrast, Noah Webster's Dictionary of the English Language, the first comprehensive American dictionary (published in 1807), defined "conscience" as: "natural knowledge, or the faculty that decides on the right or wrong of actions in regard to one's self."431 Similarly, James' Buchanan's I757 dictionary, Linguae Britannicae Vera Pronunciatio, defined "conscience" as "[t]he testimony of one's own mind."432 And Samuel Johnson's great Dictionary of the English Language gave as the first definition: "The knowledge or faculty by which we judge of the goodness or wickedness of ourselves." 433 In none of these definitions was there specific reference to religion, although about half of the literary examples Johnson gave in the four volume edition had a religious context. ${ }^{434}$

On the other hand, outside of dictionaries, the vast preponderance of references to "liberty of conscience" in America were either expressly or impliedly limited to religious conscience. 435 A few examples suffice to make the point; dozens of others would do as well. St. George

id. Significantly, Richards uses a vocabulary that was deliberately rejected by the framers. He talks of "toleration," although the framers condemned the concept of toleration. See supra pp. 1443-49. And he speaks of "conscience," when the framers considered drafts employing the term and chose to use the term "religion" instead.

428 D. RiCHARDS, supra note 54 , at I4r.

${ }^{429}$ See Freeman, The Misguided Search for the Constitutional Definition of "Religion," 7 I GEo. L.J. 1519, 1520 ( 1983 ). For example, the Virginia Bill of Rights defined "religion" as "the duty which we owe to our Creator, and the manner of discharging it." Virginia Bill of Rights of 1776 , $\$ 16$, reprinted in 2 FEDERAL AND STATE Constitutions, supra note 2, at igo8, Igog.

430 Madison, for example, deliberately chose terms other than "God" to refer to the object of religious homage, including "Creator," "Governor of the Universe," and "Universal Sovereign." J. MAdison, Memorial and Remonstrance, supra note Iog, at I84-85. This suggests an attempt at a definition more compendious than the familiar Judeo-Christian God, but it retains the distinction between transcendent authority and personal judgment. See Freeman supra note 429 , at I52 I-23; Ingber, supra note 429 , at $25 \mathrm{I}$. The literature on the meaning of "religion" under the first amendment is vast. See id. at 233 n.3.

431 N. WEBSTER, supra note 252.

$432 \mathrm{~J}$. BUCHANAN, supra note $25 \mathrm{I}$.

433 S. JoHnson, supra note 252.

434 See id.

435 See I A. SToKes, supra note 280, at 16-17; Adams \& Emmerich, supra note 17, at 1599 n. 174 . 
Tucker's I803 commentary on American constitutional law divided "[t]he right of personal opinion" into two subcategories: "liberty of conscience in all matters relative to religion" and "liberty of speech and of discussion in all speculative matters, whether religious, philosophical, or political."436 Madison himself used the terms "free exercise of religion" and "liberty of conscience" interchangeably when explaining the meaning of the first amendment. ${ }^{437}$ The laws of at least ten of the states expressly linked "liberty of conscience" to religion. The Massachusetts Charter of I69I provided that "a liberty of Conscience [be] allowed in the Worshipp of God to all Christians (Except Papists),"438 and the Connecticut legislature passed a similar measure in I784, entitled "An Act for securing the Rights of Conscience in Matters of Religion, to Christians of every Denomination."439 The Carolina proprietors' Agreement with proposed settlers granted "liberty of conscience in all religious and spiritual things." 440 Maryland's Toleration Act of I649 declared "the enforcing of the conscience in matters of Religion . . . to be of dangerous consequence. $" 441$

Religious and popular writings also linked conscience and religion. Elisha Williams, sometime president of Yale, wrote a pamphlet in I 744 called The essential Rights and Liberties of Protestants. A seasonable Plea for the Liberty of Conscience, and The Right of private Judgment in Matters of Religion without any Control from Human Authority. ${ }^{442}$ Virginia Baptist leader John Leland's pamphlet, The Rights of Conscience Inalienable, focused on attacking religious establishments and state-supported religion. ${ }^{443}$ There was no recorded controversy in preconstitutional America in which the right of "conscience" was invoked on behalf of beliefs of a political, social, philosophical, economic, or secular moral origin.

In any event, the final version of the amendment adopted by Congress and ratified by the states omitted any reference to "rights of conscience" and protected the "free exercise of religion" instead. There

436 ST. GeORge TuCker, BlaCkstone's CoMmentaries, reprinted in 5 The Founders' Constitution, supra note 72 , at 96-97.

${ }^{437}$ See e.g., Madison, Report on the Virginia Resolutions (Jan. 18, 1800), reprinted in 5 THE Founders' Constitution supra note 72 , at 141 .

438 Mass. Bay Charter of 1691, reprinted in I Federal and State Constitutions, supra note 2 , at 942,950 .

439 T. CURRY, supra note I7, at I80 (quoting ACTS AND LAwS of the STATE OF ConNectICUT 2I-22).

$440 \mathrm{~S}$. COBB, supra note 17 , at 116.

441 Id. at 376; see also id. at 293-94 (New Hampshire): id. at 303-04, 308, 323-54 (New York); id. at $40 \mathrm{I}-02$ (New Jersey); id. at $4 \mathrm{Ig}$ (Georgia); id. at $43 \mathrm{I}$ (Rhode Island).

42 See T. CuRry, supra note 17 , at $97-98$ \& n.59 (citing E. Willians, The essentiat RightS AND Liberties of ProtestaNts (Boston I 744 )).

${ }^{443}$ See J. LELAND, supra note 574 , at $179-92$. 
are two possible explanations for this. The reference to conscience could have been dropped because it was redundant, or it could have been dropped because the framers chose to confine the protections of the free exercise clause to religion."

The "redundancy" explanation can be supported by the absence of any recorded speech or discussion of differences between the terms. ${ }^{444}$ The drafters alternated between the two formulations without apparent pattern, ${ }^{445}$ and participants in the debate later referred to the free exercise clause as a "liberty of conscience" provision without apparent awareness of the difference in denotation.

Still, the theory that the phrase "free exercise of religion" was deliberately used in order to exclude nonreligious conscience seems more likely, since the different drafts called attention to the question. If no distinction was intended, it would have been more natural to stick with a single formulation and to concentrate on the wording of the contested establishment clause. This theory also derives support from Samuel Huntington's comment that he hoped "the amendment would be made in such a way as to secure the rights of conscience, and a free exercise of the rights of religion, but not to patronize those who professed no religion at all."446

It derives further support from the debate over a proposed constitutional exception for those "religiously scrupulous of bearing arms."447 Representative Thomas Scott of Pennsylvania opposed the clause, stating:

There are many sects I know, who are religiously scrupulous in this respect; I do not mean to deprive them of any indulgence the law affords; my design is to guard against those who are of no religion. It has been urged that religion is on the decline; if so, the argument is more strong in my favor, for when the time comes that religion shall be discarded, the generality of persons will have recourse to these pretexts to get excused from bearing arms. ${ }^{448}$

444 The sole exception is the objection posed by the Virginia State Senate to the first amendment, discussed above at text accompanying note 385 , which can be read as distinguishing between the terms.

445 The Senate adopted three different versions of the religion clauses in turn, which included three different formulations of the establishment provision, each of which was coupled with either a "free exercise of religion" clause or a "rights of conscience" clause. See supra pp. 148384. There is no apparent pattern that might connect the free exercise/liberty of conscience terminology with the establishment formulations. The term "free exercise" seems to be associated with both the broadest and the narrowest conceptions of disestablishment, and "rights of conscience" associated with the intermediate establishment provision. It is difficult to harmonize this with an understanding of religious liberty.

446 I ANNALS OF CoNG. 758 (J. Gales ed. I834) (Aug. 15, 1789).

447 See infra pp. 1500-03.

448 I ANnals of Cong. 796 (J. Gales ed. I834) (Aug. 20, 1789). 
Why the proposed language ("religiously scrupulous") was not adequate for Scott's purposes is hard to say, but his underlying view of the proper scope of free exercise exemptions is clear: they should be reserved for cases of conflict with actual religious beliefs. Elbridge Gerry expressed a similar view. 449

In any event, it does not matter which explanation - redundancy or intentionality - is correct, for under either explanation, nonreligious "conscience" is not included within the free exercise clause. If "the rights of conscience" were dropped because they were redundant, "conscience" must have been used in its narrow, religious, sense. If the omission was a substantive change, then the framers deliberately confined the clause to religious claims. Neither explanation supports the view that free exercise exemptions must be extended to secular moral conflicts.

The textual insistence on the special status of "religion" is, moreover, rooted in the prevailing understandings, both religious and philosophical, of the difference between religious faith and other forms of human judgment. Not until the second third of the nineteenth century did the notion that the opinions of individuals have precedence over the decisions of civil society gain currency in American thought. In I789, most would have agreed with Locke that "the private judgment of any person concerning a law enacted in political matters, for the public good, does not take away the obligation of that law, nor deserve a dispensation." 450

Religious convictions were of a different order. Conflicts arising from religious convictions were conceived not as a clash between the judgment of the individual and of the state, but as a conflict between earthly and spiritual sovereigns. The believer was not seen as the instigator of the conflict; the believer was simply caught between the inconsistent demands of two rightful authorities, through no fault of his own. This understanding was grounded in the Protestant doctrine of "two kingdoms," taught by both Calvin and Luther, ${ }^{451}$ and had still older roots in Augustinian thought. 452

449 I ANNALS OF Cong. 779 (J. Gales ed. 1834) (Aug. 17, 1789) (reporting that Gerry "wished the words to be altered so as to be confined to persons belonging to a religious sect scrupulous of bearing arms").

$450 \mathrm{~J}$. LoCKE, A Letter Concerning Toleration, supra note $\mathrm{II}_{3}$, at 43 . Locke wrote:

[E]very man, by consenting with others to make one Body Politic under one Government, puts himself under an Obligation to every one of that Society to submit to the determination of the majority, and to be concluded by it; or else this original Compact . . . would signifie nothing, and be no Compact . . . .

J. Locke, The Second Treatise of Government, supra note $\mathrm{r} 34, \S 97$, at 376 (emphasis in original).

451 See 2 J. Calvin, Institutes of the Christian Religion 1485 (J. McNeill ed. 1960); M. LUTHER, Temporal Authority: To What Extent It Should Be Obeyed, in 45 LUTHER's Works 8I, 89-129 (W. Brandt ed. I962).

452 See St. Augustine, The City of God 376-77 (M. Dods ed. 1950). For a brief discussion of "two kingdoms" doctrine and its relation to religious liberty, see Adams \& Em- 
Not only were the spiritual and earthly authorities envisioned as independent, but in the nature of things the spiritual authorities had a superior claim. "[O]bedience is due in the first place to God, and afterwards to the laws," according to Locke. ${ }^{453}$ The American conception of religious liberty was accordingly defended in those terms. The key passage in Madison's Memorial and Remonstrance reads as follows:

Before any man can be considered as a member of Civil Society, he must be considered as a subject of the Governor of the Universe: And if a member of Civil Society, who enters into any subordinate Association, must always do it with a reservation of his duty to the general authority; much more must every man who becomes a member of any particular Civil Society, do it with a saving of his allegiance to the Universal Sovereign. ${ }^{454}$

Far from being based on the "respect for the person as an independent source of value," 455 the free exercise of religion is set apart from mere exercise of human judgment by the fact that the "source of value" is prior and superior to both the individual and the civil society. The freedom of religion is unalienable because it is a duty to God and not a privilege of the individual. The free exercise clause accords a special, protected status to religious conscience not because religious judgments are better, truer, or more likely to be moral than nonreligious judgments, but because the obligations entailed by religion transcend the individual and are outside the individual's control.

It is important to remember that the framers and ratifiers of the first amendment found it conceivable that a God - that is, a universal and transcendent authority beyond human judgment - might exist. If God might exist, then it is not arbitrary to hold that His will is superior to the judgments of individuals or of civil society. Much of the criticism of a special deference to sincere religious convictions arises from the assumption that such convictions are necessarily mere subcategories of personal moral judgments. ${ }^{456}$ This amounts to a denial of the possibility of a God (or at least of a God whose will is made manifest to humans). But while this skeptical position is tenable

merich, cited above in note 17 , at $1623^{-24}$; see also Cover, Obligation: $A$ Jewish Jurisprudence of the Social Order, 5 J.L. \& RELIGION 65 ( 1987 ) (contrasting the Jewish jurisprudence of obligation with the liberal jurisprudence of rights); Garvey, Free Exercise and the Values of Religious Liberty, r8 CoNN. L. Rev. 779, 798-801 (1986) (drawing an analogy between religion and insanity to assert that "religious claimants [are] different from other people, and therefore deserving of special constitutional protection"); Note, Religious Exemptions Under the Free Exercise Clause: A Model of Competing Authorities, 90 YALE L.J. 350 (I980) (advocating a "model of competing authorities" to replace current exemption doctrine).

$453 \mathrm{~J}$. LOCKE, A Letter Concerning Toleration, supra note $\mathrm{II} 3$, at 43.

454 J. Madison, Memorial and Remonstrance, supra note Io9, at 185 .

455 D. RICHARDS, supra note 54 , at 142.

456 See, e.g., R. DWORKIN, supra note $42 \mathrm{I}$, at 200-or. 
as a theoretical or philosophical proposition, it is a peculiar belief to project upon the framers and ratifiers of the first amendment, for whom belief in the existence of God was natural and nearly universal. It is an anachronism, therefore, to view the free exercise clause as a product of modern secular individualism. From the perspective of the advocates of religious freedom in 1789 , the protection of private judgment (secular "conscience") fundamentally differs from the protection of free exercise of religion.

The religious distinction between the City of God and the City of Man had its counterpart in secular Enlightenment thought. Religious belief, as Locke argued in his Third Letter for Toleration, "is not capable of demonstration"; it is not, therefore, "capable to produce knowledge, how well grounded and great soever the assurance of faith may be wherewith it is received; but faith it is still, and not knowledge; persuasion, and not certainty." 457 Natural law and morality, on the other hand, are subjects for rational inquiry and knowledge. That is the epistemological premise of Locke's scientific investigations into psychology and politics.

The "magistrates of the world" thus have no authority to coerce individuals on account of religious opinion, for in this sphere they can have no basis for action other than "their own belief, their own persuasion," 458 which is as likely to support the false as the true religion. As Madison observed, "that the Civil Magistrate is a competent Judge of Religious truth . . . is an arrogant pretension."459 By contrast, the very purpose of civil society is to grant the magistrate authority to coerce all members of society to comply with the rational principles that order human affairs. ${ }^{460}$ When individuals err (however conscientiously) in their judgments about earthly things - politics, economics, natural morals - the magistrate is, and must be, empowered to correct them. It is no usurpation of authority for the government to use its power in these cases. Only when the individual's judgment is grounded in beliefs outside the ken of government is the government required to defer.

A distinction between religious and secular conscience is, therefore, consistent both with the religious and the Enlightenment perspective on free exercise. From the religious point of view, the difference

457 J. Locke, A Third Letter for Toleration, in 6 WORKS OF LOCKE, supra note III, at 139, I44 [hereinafter J. LockE, Third Letter for Toleration]; of. T. HOBBES, supra note II9, at 242 (contrasting the "principles of nature," which our "experience has found true," with matters that depend on the "supernatural revelations of the will of God"). This casts doubt on Professor Richards' assumption that religious judgment is an exercise of Kantian practical reason. See

D. RICHARDS, supra note 54 , at 136 .

$458 \mathrm{~J}$. Locke, Third Letter for Toleration, supra note 457 , at $\mathbf{1 4 3 .}$

459 J. Madison, Memorial and Remonstrance, supra note 109, at 187.

460 See J. Locke, The Second Treatise of Government, supra note $134, \$ \S 87-89$, at $366-$ 69. 
between religious and secular forms of conscience is that the former represent an obligation to an authority higher than the individual, while the latter are manifestations of mere individual will or judgment. From the Enlightenment point of view, the difference is that the government has no basis for evaluating the truth of religious claims, while it inevitably must evaluate claims based on rational inquiry and knowledge. The religious view emphasizes the importance of the individual; the Enlightenment, the incapacity of the government. Madison combined these points in his Memorial and Remonstrance. ${ }^{461}$ Both perspectives lead to the same conclusion: it is sensible to restrict the power of government to influence or coerce religious conscience, even when government has the power to influence or coerce judgments based on science, history, political ideology, economics, moral philosophy, or other secular sources.

This raises the question whether the free exercise clause protects atheists or other unbelievers. As previously noted, Locke excluded atheists from his proposed system of religious toleration, while Jefferson departed from Locke in this respect. ${ }^{462}$ Six of the state constitutions as of I789 confined free exercise protections to theists, two (Virginia and Delaware) were ambiguous, and four extended protection to all religious beliefs without limitation. Since the free exercise clause of the federal Constitution contained no limitation, it is most plausible to assume that, in this as in other respects, it was imitating the more expansive of the state provisions. But this begs the question of what free exercise protection might mean for a person who does not recognize any form of transcendent, extrapersonal authority - to a person who does not "exercise" a "religion."

For the most part, the prohibition on an establishment of religion should suffice to protect unbelievers from discrimination, ill-treatment, or coercion (from test oaths, for example). ${ }^{463}$ There should be no doubt that government action that abridges the unbeliever's right not to engage in or support a religious practice is unconstitutional. By I 789, it was generally agreed that compelled homage is of no value to God or to man. In Madison's words, "[i]t is the duty of every man to render to the Creator such homage, and such only, as he believes to be acceptable to him."464

As a practical matter, the question whether the free exercise clause protects atheists arises only with reference to claims for exemption.

461 See J. MAdison, Memorial and Remonstrance, supra note 109, at 184-85.

462 See supra text accompanying notes I2I \& 213.

463 See Torcaso v. Watkins, 367 U.S. 488 (196r). In Torcaso, the Court did not specify which of the two religion clauses the test oath violated. Under the analysis here, a test oath is an establishment of religion under any circumstances, since it coerces an affirmation of a religious belief. However, a test oath is a violation of the free exercise rights only of those whose religions forbids taking the oath.

464 J. Madison, Memorial and Remonstrance, supra note Io9, at 184. 
If it is true that the right to exemption from generally applicable laws on ground of conflict with religious doctrine is confined to those who have duties arising from their religious beliefs, then it has no application to unbelievers. Unbelievers undoubtedly make judgments of right and wrong that sometimes conflict with generally applicable law. But if these do not stem from obedience to a transcendent authority prior to and beyond the authority of civil government, they do not receive exemption under the free exercise clause. To subject an atheist to civil disabilities would be a violation of free exercise; but to require an atheist who objects to war on secular grounds to go to war would not, since his conduct is not (and by definition could not be) motivated by his religious belief.

4. The Militia Exemption Clause. - Although the debates in the First Congress over the free exercise clause itself did not explicitly raise the question of exemptions, the question arose during the debate over what would become the second amendment, in connection with service in the state militias. Three states (North Carolina, Virginia, and Rhode Island) had proposed that "any person religiously scrupulous of bearing arms ought to be exempted, upon payment of an equivalent to employ another to bear arms in his stead."465 Madison's draft bill of rights contained a similar proposal, appended to what is now the second amendment, although Madison left the requirement of a substitute to legislative discretion. 466 The Select Committee proposed and the House of Representatives debated a more generous exemption: "no person religiously scrupulous shall be compelled to bear arms."467 The proposal was quite controversial; it passed the House by a mere $24-22$ vote and was rejected by the Senate. Since this is the only discussion in the First Congress specifically bearing on religious exemptions from generally applicable legal duties, it warrants detailed consideration.

The most eloquent defender of the proposal, Representative Elias Boudinot of New Jersey, Presbyterian and later President of the American Bible Society, hoped "that in establishing this Government, we may show the world that proper care is taken that the Government may not interfere with the religious sentiments of any person." $468 \mathrm{He}$ argued that it would be both pointless and unjust to compel "men who are conscientious in this respect . . . to bear arms, when, according to their religious principles, they would rather die than use them." 469

\footnotetext{
465 I Elliot's Debates, supra note 165 , at 335 (quoting from the Rhode Island ratification of the Constitution, May 29, 1790).

466 "[N]o person religiously scrupulous of bearing arms shall be compelled to render military service in person." I ANNALS OF CONG. $45 \mathrm{I}$ (J. Gales ed. 1834) (June 8, I789).

467 Id. at 778 (Aug. I7, I789).

468 Id. at 796 (Aug. 20, I789).

469 Id.
} 
One may wonder why, if this is so, objectors were not protected under the free exercise clause without need for a separate provision. ${ }^{470}$ There are at least three possible answers. First, the militias are arms of the state governments except when in actual service; thus, the free exercise clause probably did not apply to them. Second, it does not necessarily follow from the fact of free exercise exemptions that the particular case of military service will be held protected. That determination will depend, in part, on the judiciary's assessment of the governmental interest in conscription. Thus, even if Boudinot expected conscientious objection from military service to be protected under the free exercise clause, it was prudent to spell it out. Third, as Boudinot pointed out, if Congress struck out the militia exemption clause, this would create an inference that there is an intention in the general government to compel all its citizens to bear arms. Indeed, some scholars have cited Congress' rejection of the militia exemption clause as conclusive evidence that there is no constitutional right to conscientious objection from military service. ${ }^{471}$

The significance of Boudinot's position for present purposes is that he, with a majority of the House, considered exemption from a generally applicable legal duty to be "necessary" to protect religious freedom. Whether or not the particular application of this principle to bearing arms would be accepted by the Senate (it was not) ${ }^{472}$ or the courts (it was not), ${ }^{473}$ it strongly suggests that the general idea of free exercise exemptions was part of the legal culture.

Opposition to the militia exemption clause arose on two grounds. First, James Jackson, Revolutionary War hero and representative from Georgia, commented that it would be "unjust" to require "one part" of the nation "to defend the other in case of invasion."474 If he had left it at that, this argument would resemble the modern antiexemptions view that to exempt some citizens from legal obligations on religious grounds constitutes an unconstitutional preference for religion. 475 Jackson went on to propose, however, that the militia exemption clause be amended by inserting at the end of it, "upon paying an equivalent, to be established by law." 476 This demonstrates that Jackson's objection was not to the principle of exemption, but to the extent of the accommodation in this particular case. Taken as a

470 See Marshall, supra note 17 , at 76 ("[T] $]$ he fact that a conscientious objection amendment was proposed suggests that the free exercise clause was not thought, by itself, to provide for religious exemptions from neutral laws.").

471 See W. BERNS, supra note 13 , at 54-55; M. MalBIN, supra note I7, at 39-40 \& n.4.

472 See I ANNALS OF CONG. 779 (J. Gales ed. 1834) (remark of Rep. Jackson, Aug. I7, I789).

473 See, e.g., United States v. MacIntosh, 283 U.S. 605, 623-25 (I93 I).

474 I ANnals of Cong. 779 (J. Gales ed. I834) (remark of Rep. Jackson, Aug. 17, 1789).

475 See Marshall, supra note 17 , at 30-35.

476 I ANNALS OF CoNg. 779 (J. Gales ed. I834) (remark of Rep. Jackson, Aug. I7, I789). 
whole, Jackson's position must be counted as favoring exemptions for religious conscience, but balancing the interests of believers and nonbelievers somewhat differently.

The most cogent argument against the militia exemption clause came from Egbert Benson of New York. Benson argued that "[n]o man can claim this indulgence of right. It may be a religious persuasion, but it is no natural right, and therefore ought to be left to the discretion of the Government."477 Benson did not oppose religious exemptions in principle, however. On the contrary, he had "no reason to believe but the Legislature will always possess humanity enough to indulge this class of citizens in a matter they are so desirous of; but they ought to be left to their discretion." "478 Though he considered religious exemption from military service "humane" and "benevolent," he did not think it fell within the class of natural rights. Accordingly, he could not support its inclusion in the Bill of Rights.

Benson's position is a sophisticated version of the "judicial restraint" or "separation of powers" argument against recognizing exemptions under the free exercise clause. He distinguished between the functions of the legislature and the judiciary, confining the latter to enforcing natural law positively enacted in the Constitution. There is no doubt that Benson, like the other participants in the debate, understood that by constitutionalizing the principle of militia exemptions they were transferring decisionmaking authority from the legislature to the courts. Benson felt that "[i]f it stands part of the constitution, it will be a question before the Judiciary on every regulation you make with respect to the organization of the militia."479 No one challenged this assumption. Marbury $v$. Madison 480 was thirteen years in the future, but Benson and the others clearly anticipated that governmental action would be judicially reviewable under the Bill of Rights.

Nonetheless, Benson's position was ambiguous on the key question of interest here. Did he believe there is no natural right to exemption from militia service because there is no natural right to exemption from any generally applicable law? Or did he believe there is no natural right to exemption from militia service because the government's interest is potentially compelling, and the degree of necessity for universal military service must be left to legislative discretion? The latter seems slightly more probable. Benson stated he "would

477 Id. at 780 (motion of Rep. Benson, Aug. I7, 1789).

478 Id. This point was echoed by Thomas Scott of Pennsylvania, who said that he conceived exemption from militia service "to be a legislative right altogether." Id. at 796 (objection of Rep. Scott, Aug. 20, 1789). His main "design," though, was to ensure that exemptions were not extended to the nonreligious. See id.

479 I AnNals of Cong. 780 (J. Gales ed. 1834) (Aug. I7, 1789).

${ }^{480} 5$ U.S. (I Cranch) I37 (I803). 
always leave it to the benevolence of the Legislature, for, modify it as you please, it will be impossible to express it in such a manner as to clear it from ambiguity."481 Although this statement is far from conclusive, it suggests that Benson's opposition to the exemptions was based on the impossibility of capturing in language the great variety of circumstances that would influence the grant or denial of exemptions in any particular case in the future. If so, it does not necessarily imply that he would disagree with the modern construction of the free exercise clause.

\section{Early Judicial Interpretation}

The religion clauses of the federal and state constitutions did not engender many lawsuits in the early years of the Republic, and fewer still raised the question of free exercise exemptions. The largest volume of litigation was over the competency to testify in court of those, like Universalists, who did not believe in a future state of rewards and punishments. There were also a number of blasphemy prosecutions that raised issues under the religion clauses. Since both of these categories of cases involved laws specifically directed at religion, they did not raise the exemption question.

The free exercise clause of the federal Constitution generated no reported decisions at all until 1845 . Permoli $v$. Municipality No. $I,{ }^{482}$ the Supreme Court's first free exercise case, involved a municipal ordinance prohibiting open-casket funerals by Catholic priests except when performed at a single city-approved obituary chapel. In substance (though not in form), this was a generally applicable regulation, since the Protestants conducted services for the dead at graveside, leaving Catholics the only denomination performing open-casket funerals in the area to which the prohibition applied. Justice Catron's opinion for a unanimous Court is uninformative about the meaning of the free exercise clause. It holds only that "[t]he Constitution makes no provision for protecting the citizens of the respective states in their religious liberties; this is left to the state constitutions and laws." 483 But it is suggestive that counsel for the city felt it necessary to defend the ordinance under the "law of necessity" in light of its purpose to prevent the spread of yellow fever. ${ }^{484}$ This may indicate that the legal profession believed that interference with religious activities required compelling justification.

481 x ANnals of Cong. 779-8o (J. Gales ed. 1834) (statement of Rep. Benson, Aug. I7, I 789).

48244 U.S. (3 How.) 588 (1845).

483 Id. at 609.

${ }^{484}$ See id. at 6or (argument of counsel). 
In the state courts, there was only one reported case involving a religious exemption claim during the twenty years following ratification of the first amendment. Unfortunately, it is nothing more than a cryptic paragraph in Dallas' reports from the Supreme Court of Pennsylvania. ${ }^{485}$ The reporter's summary of the case states the holding as follows: "A Jew refusing to be sworn as a witness, because it was Saturday, his Sabbath, the Court fined him $£$ Io."486

The earliest state court decision expressly addressing the exemption question was the case with which this Article began, People v. Philips. ${ }^{487}$ It involved the exemption of a Catholic priest from compliance with a subpoena requiring him to testify to matters he heard in the confessional. Noting that "this is a great constitutional question, which must not be solely decided by the maxims of the common law, but by the principles of our government," 488 the court (through the Honorable DeWitt Clinton, then mayor, later governor, and candidate for President against Madison in I8I2) construed the New York Constitution to hold that the priest must be exempted from the subpoena requirement. "It is essential to the free exercise of a religion, that its ordinances should be administered - that its ceremonies as well as its essentials should be protected," the court noted. "To decide that the minister shall promulgate what he receives in confession, is to declare that there shall be no penance; and this important branch of the Roman Catholic religion would be thus annihilated."489 The court thought it so obvious that "[e]very man who hears me will answer in the affirmative" that a law of the state that prevented administration of one of the Protestant sacraments would be unconstitutional. The same right belongs to the Catholics. 490

The court's argument bears on the issue of neutrality among religious beliefs. The court did not believe it was granting Catholics a benefit to which persons of other beliefs are not entitled. Rather, it saw the exemption as necessary to ensure that Catholics are treated no worse than Protestants would be treated under comparable circumstances. Since it was inconceivable that the Protestant majority of New York would so seriously interfere with the administration of

485 See Stansbury v. Marks, 2 Dall. 213 (Pa. 1793).

$486{ }_{2}$ Dall. at xv. The full case description suggests, however, that the actual outcome was less repressive than the holding. It recounts that the witness was fined for his refusal to testify, but that the defendant waived the benefit of his testimony, whereupon the fine was discharged.

See Stansbury v. Marks, 2 Dall. at 213.

487 Court of General Sessions, City of New York (June I4, I813). This case was not officially reported, but a full record of the arguments and opinion are found in W. SAMPSON, supra note $\mathrm{I}$, at 9, excerpted in Privileged Communications to Clergymen, supra note $\mathrm{I}$, at 199.

488 Privileged Communications to Clergymen, supra note $\mathbf{I}$, at 206.

489 Id. at 207.

490 Id. 
Protestant sacraments, the court had the responsibility of extending the same right to the Roman Catholic minority.

The court responded in two ways to the prosecutor's argument that "the peace or safety of the state" 491 requires enforcement of the subpoena. First, it noted that as a functional matter priest-penitent confidentiality often served as an "instrument of great good":492 "The sinner may be admonished and converted from the evil of his ways: Whereas if his offence was locked up in his own bosom, there would be no friendly voice to recall him from his sins . . ."493 The question is not whether concealment of information is a public injury in any particular case, but whether "the natural tendency of it is to produce practices inconsistent with the public safety or tranquility."494 Second, the court argued that the proviso applies to "acts committed, not to acts omitted."495 The state may override free exercise claims when the claimant's actions would injure the public, but it may not do so to compel affirmative public benefits.

The very fact that the court evaluated the strength of the government's interest in enforcing a subpoena under the "peace or safety" standard confirms that such state provisos were understood to limit legislative authority from encroaching on religious liberty even through generally applicable laws. The court concluded as follows:

Although we differ from the witness and his brethren, in our religious creed, yet we have no reason to question the purity of their motives, or to impeach their good conduct as citizens. They are protected by the laws and constitution of this country, in the full and free exercise of their religion, and this court can never countenance or authorize the application of insult to their faith, or of torture to their consciences. 496

Four years after this decision, another New York municipal court distinguished the Philips decision and denied the motion of a defendant in a murder trial to bar testimony of a Protestant clergyman to whom he had confessed while in prison. 497 The clergyman informed the court that he had no objection to testifying, whereupon the court ruled "that the testimony was admissible, and took distinction between auricular confessions made to a priest in the course of discipline, according to the canons of the Church, and those made to a minister

491 Id. at $207-08$.

492 Id. at 208.

493 Id.

494 Id.

495 Id.

496 Id. at 209. By "country," the court presumably meant New York.

497 See People v. Smith, 2 City Hall Recorder (Rogers) 77 (N.Y. I8I7), reprinted in Privileged Communications to Clergymen, supra note I, at 209. 
of the gospel in confidence, merely as a friend or adviser."498 The logic appears to be that no violation of religious tenets was involved. In response to this decision, the New York legislature passed a statute forbidding any minister or priest "of any denomination whatsoever" from disclosing "any confessions made to him in his professional character." 499

Similarly, the Supreme Judicial Court of Massachusetts refused, without explanation, to overturn a criminal conviction based on a confession made by a man to the members of his church. 500 The defendant had contended that it would be "in some shape an infringement of the rights of conscience, to make use of confessions, made under these circumstances ... [where] in a theological view, he is obliged in conscience to perform it." 501 Counsel for the prosecution argued that the defendant's confession was "purely voluntary" and was not "required by any known ecclesiastical rule"502 but did not contest the validity of the defendant's interpretation of freedom of conscience. ${ }^{503}$ It is, of course, impossible to tell whether the Supreme Judicial Court accepted the defendant's legal theory, since it stated no reasons for its decision. But it is noteworthy that the prosecution confined its argument to the facts and did not contest the defendant's interpretation of constitutional principles.

The most interesting line of cases arose in the Supreme Court of Pennsylvania. The first, Commonwealth $v$. Wolf, 504 involved a challenge by a Jewish merchant, Abraham Wolf, to Pennsylvania's Sunday closing law, on the ground that as applied to one who observed Saturday as his day of rest and worship, it conflicted with the commonwealth's constitutional protection of the rights of conscience. The challenge was rejected, but on grounds that would admit the principle of free exercise exemptions. The dispositive question as the court posed the case was not whether the state constitution required exemptions, but whether the law conflicted with Wolf's religious conscience. Wolf's attorney conceded that Jewish doctrine does not "immediately" require work on Sunday; it is possible for a Jewish merchant to comply with the Sunday closing law without violating religious duty. But the attorney attempted an ingenious argument that enforcement of the Sunday closing laws, in conjunction with the

498 Privileged Communications to Clergymen, supra note I, at $2 \mathrm{II}$.

499 N.Y. REv. STAT. I828, pt. 3, ch. 7 , tit. 3, \$ 72.

500 Commonwealth v. Drake, 15 Mass. I6I (18I8).

501 Id. at I6I.

502 Id. at $16 \mathrm{I}-62$.

503 There was no doubt that the defendant's claim was understood to be based in part on the Massachusetts Constitution. Counsel for the prosecution referred to the claim as a "legal or constitutional principle." Id. at $\mathrm{x} 6 \mathrm{I}$.

${ }^{504} 3$ Serg. \& Rawle 48 (Pa. 1817 ). 
Jewish law forbidding work on Saturday, would force the plaintiff to violate the fourth commandment: "six days shalt thou labour, and do all that thou hast to do." 505 The court rejected this argument not in theory, but on the facts: "the Jewish Talmud, containing the traditions of that people, and the Rabbinical constitutions and explications of their law, asserts no such doctrine."506 If there were no such doctrine, there would be no burden on Wolf's liberty of conscience and hence no ground for granting an exemption. The unstated assumption was that if the law had required Wolf to violate his conscience, he might have had a claim. 507

The next two Pennsylvania cases, Commonwealth v. Lesher ${ }^{508}$ and Simon's Executors v. Gratz, ${ }^{509}$ both contain opinions by Chief Justice John Bannister Gibson, a highly regarded jurist who is best known today for his dissenting opinion in Eakin $v$. Raub, 510 in which he rebutted Chief Justice Marshall's position in Marbury that the judiciary has authority to declare void unconstitutional acts of the legislature. ${ }^{511}$ Gibson also was the foremost judicial opponent of free exercise exemptions in the nineteenth century. His decision in Simon's Executors was the leading precedent in the thirteen original states prior to the Civil War for the proposition that free exercise does not include the right of exemption from generally applicable law. An examination of Gibson's opinions in Lesher and Simon's Executors shows that his rejection of constitutional judicial review and his position on free exercise exemptions were closely related.

In Lesher, a prospective juror had been excluded for cause from jury service in a capital case, on the basis of his religious objection to capital punishment. ${ }^{512}$ The defendant was convicted and appealed on the ground that the juror's exclusion had been unlawful. ${ }^{513}$ On appeal, the majority affirmed the conviction on the basis of the state's interest in obtaining a trial in which the jurors complied with the law, without finding it necessary to address the religion clauses of the state constitution. ${ }^{514}$ Gibson dissented on the ground that religious scruples

505 Id. at 50.

506 Id.

507 The case was a precursor to Braunfeld v. Brown, 366 U.S. 599 (I96r), in which the United States Supreme Court rejected a similar challenge to a Sunday closing law by a Jewish merchant. Whether such a challenge should succeed under the modern doctrine of free exercise exemptions is a close question. See McConnell \& Posner, supra note 20, at 4I-42.

508 I7 Serg. \& Rawle 155 (Pa. 1828).

5092 Pen. \& W. 412 (Pa. I83I).

510 I2 Serg. \& Rawle 330 (Pa. 1825).

511 See id. at 356 (Gibson, C.J., dissenting). Gibson added one caveat: the judiciary could declare state laws that violate the federal Constitution void, there being an express grant of such power under the supremacy clause. See id. at 356-57.

512 See Lesher, 17 Serg. \& Rawle at 155.

513 See id.

514 See id. at $156-60$. 
cannot be a basis for exemption from a civic duty, such as jury service. ${ }^{515}$

Gibson's Lesher dissent formed the basis for a majority holding in Simon's Executors. In that case, a contract action had been set for trial on a Saturday and the plaintiff, Levi Philips, who was Jewish, moved for a continuance on the ground that "he had scruples of conscience against appearing in court to-day, and attending to any secular business; and that he believes his presence and aid will be material in the progress of the cause."516 The motion was denied; Philips' counsel took a nonsuit and appealed on the basis of the liberty of conscience clause of the Pennsylvania Constitution. ${ }^{517}$ The decision was affirmed, in another opinion by Gibson. ${ }^{518}$

In his Simon's Executors opinion, Gibson expressly disapproved the New York precedent of People v. Philips, 519 which had been cited by counsel for the defendant:

No one is more sensible than I, of the benefit derived by society from the offices of the Catholic clergy, or of the policy of protecting the secrets of auricular confession. But considerations of policy address themselves with propriety to the legislature, and not to a magistrate whose course is prescribed not by discretion, but rules already established. 520

In his Lesher dissent, Gibson defined the "rights of conscience" as follows:

Simply a right to worship the Supreme Being according to the dictates of the heart; to adopt any creed or hold any opinion whatever on the subject of religion; and to do, or forbear to do, any act for conscience sake, the doing or forbearing of which, is not prejudicial to the public weal. 521

Relying on the authority of Jefferson (about whom he said "a more resolute champion of toleration perhaps never lived"522), Gibson argued that "were the laws dispensed with, wherever they happen to be in collision with some supposed religious obligation, government would be perpetually falling short of the exigence." 523 Since jury

515 See id. at I60-6I (Gibson, C.J., dissenting).

516 Simon's Executors v. Gratz, 2 Pen. \& W. 4I2, 4I2 (Pa. I83I) (quoting the deposition of Levi Philips). Presumably, this was an attempt to relitigate Stansbury v. Marks, 2 Dall. 213

(Pa. 1793), see supra p. 1504, by a relative of the original party.

517 See Simon's Executors, 2 Pen. \& W. at $4 \mathrm{r} 4$.

518 See id. at $416-18$.

519 See supra pp. 1504-05.

520 See Simon's Executors, 2 Pen. \& W. at $4 \mathrm{r} 4$.

521 Commonwealth v. Lesher, I7 Serg. \& Rawle 155, I60 (Pa. 1828) (Gibson C.J., dissenting) (emphasis in original).

522 Id.

523 Id. at $16 \mathrm{r}$. 
service is a general obligation on all citizens, and the legislature had enacted no exemption, there was no legal basis for excusing the juror. Gibson did not engage in any analysis of whether an exemption in the case would in fact be "prejudicial to the public weal," ently considering existence of the law conclusive as to its necessity. Indeed, he went out of his way to opine that the effect of refusing to exclude a juror with religious scruples against capital punishment was to grant the accused an "unreasonable advantage[." 525 "No one," he said, "is more thoroughly convinced of the . . . abstract propriety of the objection to the juror here, ${ }^{1526}$ but for Gibson the remedy lay with the legislature. 527

In Simon's Executors, Gibson explained the theoretical basis for his position. "Rightly considered," he said, "there are no duties half so sacred as those which the citizen owes to the laws." 528 "That every other obligation shall yield to that of the laws, as to a superior moral force," he wrote, "is a tacit condition of membership in every society, whether lay or secular, temporal or spiritual, because no citizen can lawfully hold communion with those who have associated on any other terms." 529 Gibson's statement may be contrasted with Madison's position in the Memorial and Remonstrance. Madison contended that religious duty "is precedent both in order of time and degree of obligation, to the claims of Civil Society."530 Gibson held that a person entering into civil society must assume the obligation of yielding to all the laws, because no other form of association is possible. Madison held that "every man" who becomes a member of a civil society "must always do it with a reservation . . . of his allegiance to the Universal Sovereign." 531 What Gibson said is impossible, Madison said is necessary. Gibson's view of the nature of religious freedom thus conflicts directly with that of one of the leading framers of the federal free exercise clause.

Gibson's rejection of the principle of judicial review, as explained in Eakin v. Raub, ${ }^{532}$ provides further reason to doubt that he represented the prevailing view on the interpretation of free exercise. Like Locke, Gibson believed in legislative supremacy. In Lesher, he attributed his conclusion to his "horror of judicial legislation"533 and said

524 Id. at 160 (emphasis omitted).

$525 \mathrm{Id}$. at 164 .

$526 I d$.

527 See id.

528 Simon's Executors v. Graz, 2 Pen. \& W. 4I2, 4I7 (Pa. I83I).

$529 \mathrm{Id}$.

$530 \mathrm{~J}$. MADISON, Memorial and Remonstrance, supra note Io9, at 184-85.

531 Id. (emphasis added).

532 See Eakin v. Raub, 12 Serg. \& Rawle 330, 344-58 (Pa. 1825) (Gibson, J., dissenting).

533 Commonwealth v. Lesher, I7 Serg. \& Rawle I55, I64 (Pa. I828) (Gibson, C.J., dissenting). 
that he "would suffer any extremity of inconvenience, rather than step beyond the legitimate province of the court."534 As discussed above, the advent of judicial review had transformed a principle of free exercise previously enforced solely through legislative action into one enforceable through the courts. ${ }^{535}$ Since virtually all of the framers and ratifiers of the first amendment expected and intended their work to be judicially enforceable, Gibson's contrary position was almost surely idiosyncratic.

Seventeen years after Simon's Executors, the Pennsylvania Supreme Court had its next free exercise exemptions case, Specht $v$. Commonwealth. ${ }^{536}$ Like Wolf, it involved a challenge to enforcement of the Sunday closing law by a sabbatarian, in this case a member of the Seventh Day Baptist Congregation. Also as in Wolf, the challenge was rejected. Toward the beginning of the opinion, the court stated that "conscientious doctrines and practices can claim no immunity from the operation of general laws made for the government and to promote the welfare of the whole people," in Lesher and Simon's Executors. Toward the end of the opinion, however, the court appeared to reject the claim on the facts, much as it had in Wolf. The court described the effect of the Sunday closing law on sabbatarians as "an incidental worldly disadvantage, temporarily injurious"538 and stated that if a person were under a religious duty both to observe Saturday as a sabbath and to work six days out of the week, "the law which compels him to inaction upon one of the six, might well be regarded as an invasion of his conscientious conviction." 539 Thus, having restated the no-exemptions precedent, the court narrowed its holding to the facts of the case, leaving open the possibility that an exemption might be granted when an actual conflict arose.

The only other religious exemption decision located from this period is State $v$. Willson, ${ }^{540}$ an 1823 decision by the Constitutional Court of South Carolina. In that case, a member of "the sect of christians usually called Covenanters" refused on ground of religious conscience to serve as a grand juror and prosecuted an appeal as a test case. ${ }^{541}$ The court unanimously rejected the claim that "a fixed $\&$ scrupulous moral objection to the discharge of a duty required by law, which springs conscientiously from the religious tenets of a man,

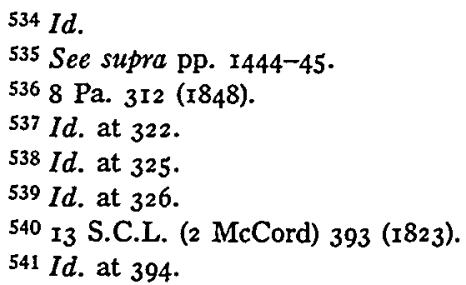


amounts to a justification for refusing to perform the duty so required." 542 The court observed that all religions required "a ready obedience to the laws of the country" and urged the Covenanter to "obey the powers that be." "543 In addition, the court expressed concern that if the sincere objections of believers were indulged, it would open the gates to the "hipocritical" and the "deceitful."544 Oddly, the court neither quoted nor cited the free exercise provision of the South Carolina Constitution.

The court's first argument in Willson proves either too much or too little. On the one hand, it suggests that there can be no religious limitation on the powers of the government, since obedience to all laws is a sacred obligation of the citizen. On the other hand, it disregards the possibility that free exercise limitations are themselves a part of the law, and that to rely on constitutional protections does not constitute disobedience to the law. The court's second argument resembles criticism of the "sincerity" requirement under modern free exercise doctrine ${ }^{545}$ and contains an implicit bias in favor of familiar religious practices and against religious practices that are not widely held and hence suspect.

It is surprising that cases involving jury service did not arise more often, since Quakers as well as Covenanters refused jury service and were not shy about pressing their claims in court. The explanation is probably that trial judges were vested with broad discretion to excuse jurors and usually did so in cases of religious objection. Indeed, such a de facto exemption had occurred in Lesher, and the court in Willson noted that it often occurred in South Carolina, as well. ${ }^{546}$ The Willson case itself was taken to the constitutional court simply to "settle a principle." 547 This strongly suggests that the actual practice favored exemptions, even though the appellate decisions went the other way.

\section{Summary of the Evidence}

While the historical evidence is limited and on some points mixed, the record shows that exemptions on account of religious scruple should have been familiar to the framers and ratifiers of the free exercise clause. There is no substantial evidence that such exemptions were considered constitutionally questionable, whether as a form of establishment or as an invasion of liberty of conscience. Even opponents of exemptions did not make that claim. The modern argument

542 Id

543 Id. at 396.

544 Id. at 394 .

545 See Marshall, supra note 17 , at 27-30.

546 See Willson, 13 S.C.L. (2 McCord) at 395-96.

547 Id. at 394 . 
against religious exemptions, based on the establishment clause, is thus historically unsupportable. Likewise unsupportable are suggestions that free exercise of religion is limited to opinions or to profession of religious opinions, as opposed to conduct.

It is more difficult to claim, on this evidence, that the framers and ratifiers specifically understood or expected that the free exercise clause would vest the courts with authority to create exceptions from generally applicable laws on account of religious conscience. Exemptions were not common enough to compel the inference that the term "free exercise of religion" necessarily included an enforceable right to exemption, and there was little direct discussion of the issue. Without overstating the force of the evidence, however, it is possible to say that the modern doctrine of free exercise exemptions is more consistent with the original understanding than is a position that leads only to the facial neutrality of legislation.

Indeed, the evidence suggests that the theoretical underpinning of the free exercise clause, best reflected in Madison's writings, is that the claims of the "universal sovereign" precede the claims of civil society, both in time and in authority, and that when the people vested power in the government over civil affairs, they necessarily reserved their unalienable right to the free exercise of religion, in accordance with the dictates of conscience. Under this understanding, the right of free exercise is defined in the first instance not by the nature and scope of the laws, but by the nature and scope of religious duty. A religious duty does not cease to be a religious duty merely because the legislature has passed a generally applicable law making compliance difficult or impossible.

The language of the free exercise and liberty of conscience clauses of the state constitutions, from the early Rhode Island, Carolina, and New Jersey charters to the new constitutions passed after I776, strongly supports this hypothesis. These constitutions curtailed free exercise rights when they would conflict with the peace and safety of society. These "peace and safety" provisos would not be necessary if the concept of free exercise had been understood as nothing more than a requirement of nondiscrimination against religion.

Moreover, in the actual free exercise controversies in the colonies and states prior to passage of the first amendment, the rights of conscience were invoked in favor of exemptions from such generally applicable laws as oath requirements, military conscription, and ministerial support. Many of the framers, including Madison, a majority of the House of Representatives in the First Congress, and the members of the Continental Congress of 1775 , believed that a failure to exempt Quakers and others from conscription would violate freedom of conscience. These experiences, while not so frequent or notorious as to warrant firm conclusions, nonetheless suggest that exemptions were part of the legal landscape. They are sufficient to shift the 
burden of persuasion to those who contend that the free exercise clause precludes exemptions.

The history subsequent to adoption of the first amendment is inconclusive but tends to point against exemptions. One lower court in New York squarely adopted the exemptions interpretation, and the supreme courts of Pennsylvania and South Carolina rejected it. None of these decisions was handed down within twenty years of the first amendment, and they are therefore weak indicators of the original understanding. The Pennsylvania holding is entitled to especially little weight since it was connected to a rejection of constitutional judicial review in general. Indeed, the contrast between the rationale of Chief Justice Gibson for the Pennsylvania court and the rationales offered by Madison for religious liberty tends, if anything, to reinforce the conclusion that Madison's position requires exemptions.

\section{Conclusion: The New American Philosophy of Religious PluRalism}

The free exercise clause may well be the most philosophically interesting and distinctive feature of the American Constitution. Viewed in its true historical light, as the product of religious pluralism and intense religious sectarianism in the American states and colonies, with limited influence from the rationalistic Enlightenment, the free exercise clause represents a new and unprecedented conception of government and its relation to claims of higher truth and authority.

Until the Protestant Reformation, the separation of church and state was the product not of theory or design but of geopolitical reality. It was graphically illustrated by the throne of St. Peter in Rome and the throne of the king in each of the nation-states of Christendom. At times, the church was under the domination of the state; at times, though more rarely, the state was under the domination of the church. More often, the church and the state were independent powers, supported by different claims of authority, acting in varying degrees antagonistically or cooperatively one with the other. This separation, a product of a "catholic" church in a post-imperial world, was instrumental in staving off incipient despotism. Mankind's two great loyalties, to God and to country, were of necessity divided; claims of ultimate right were pitted against the power of the state. "To that conflict of four hundred years," according to Lord Acton, "'we owe the rise of civil liberty." $" 1548$

The Reformation introduced religious factions to Western Europe, and with them, two novel dangers to public peace and freedom. First,

548 B. TIERNEY, Medieval Canon Law and Western Constitutionalism, in CHURCH LAW AND Constitutional Thought IN the Middle Ages, pt. XV, at 8 (1979). 
the rivalry among religious sects broke out into bloody warfare, both between countries, as in the Thirty Years War, and within countries, as in the English Civil War and the Huguenot wars in France. Second, as the universal church was sundered, it became possible to form national churches, such as the Church of England, which could be more easily dominated by the government. ${ }^{549}$ Thus, a complete and enduring fusion of earthly and spiritual authority became a serious possibility for the first time since the fall of Rome.

The Enlightenment writers on the subject tended to concentrate on the danger of religious rivalry. Sectarian intolerance and struggle for hegemony was a major cause of unrest, violence, rebellion, and persecution. There were two promising ways to ameliorate and, if possible, eliminate such violence and persecution, and both had proponents among the thinkers of the Enlightenment. One solution was to suppress religious differences by establishing a national church and supporting it with public funds. This solution was proposed by Hobbes, ${ }^{550}$ the youthful Locke, ${ }^{551}$ and Hume, ${ }^{552}$ among others. It would have two advantages: by unifying religion, it would reduce religious factionalism, and by guaranteeing financial support to the clergy, it would cause them to become indolent and subservient. The difficulty with this solution was that it would enrage dissenters from the established church (or at least the most intense among them) and might well exacerbate religious unrest. For this reason, the mature Locke proposed the second approach: to extend toleration to all (except Catholics and atheists), on condition that each religion adopt toleration as one of the tenets of its faith. Toleration, it was hoped, would calm the fevers of religious dissension. To the Enlightenment skeptic, convinced of the absurdity of the more intense varieties of religious expression and likewise convinced of the power of reason, this approach seemed to offer the additional advantage that reason, and with it rational religion, would prevail over the sectarians. Hence Jeffer-

549 See F. MAKOWER, supra note 45 , at 97 ("In the sixteenth century the reformation robbed the church almost wholly of its independence.").

550 See T. HobBES, supra note II9, pt. III, ch. 42, at 293-95; see id. at 293 ("[T] of Judging what Doctrines are fit for Peace, and to be taught the Subjects, is in all Commonwealths inseparably annexed . . . to the Soveraign Power Civill.").

551 See J. LOCKe, Two TRACTS ON Government, supra note 118 , at 124-27.

552 Hume wrote:

[E]cclesiatical establishments, though commonly they arose at first from religious view, prove in the end advantageous to the political interests of society . . . [T] he civil magistrate [should] bribe their [the clergy's] indolence, by assigning stated salaries to their profession, and rendering it superfluous for them to be farther active, than merely to prevent their flock from straying in quest of new pastures.

I D. Hume, History of ENGLAND, ch. 29, at 552-553 (1851); see also D. HuME, Idea of a Perfect Commonwealth, in Essays: Moral, Political, ANd Literary 512, 520 (E. Miller ed. 1985). 
son's hope that with religious freedom in America, all would become Unitarians. 553

An aggressive interpretation of the free exercise clause would be incompatible with the Enlightenment theory of toleration. Free exercise exemptions are likely to encourage dissident sects to maintain practices at variance with the mores of society, and thus perpetuate the very religious factionalism that is the root of the problem. While deliberate oppression of minority religious groups is counterproductive, indirect measures that increase the cost and inconvenience of exotic religious practices likely will dampen the enthusiasm for religious differentiation and thereby reduce religious strife.

As with the establishment solution, however, the toleration solution seemed less than realistic from the American side of the Atlantic. Too many Americans had come to these shores precisely because they could not practice their faith in the controlled environs of Europe. Too many sectarians were spreading their views, and religious factionalism was already too deeply ingrained. Dissenters were a vexatious minority in Britain; in America they were (in the aggregate) a large majority, divided into many sects. And experience had shown that Americans were attracted - not repulsed - by the "irrational" surges of enthusiastic religion that peaked in the Great Awakening.

Madison, for one, grasped that the United States was not amenable to the Enlightenment solutions. ${ }^{554}$ In a letter to Jefferson, he stated that "[h]owever erroneous or ridiculous these grounds of dissention and faction may appear to the enlightened Statesman or the benevolent philosopher, the bulk of mankind, who are neither Statesman nor philosophers, will continue to view them in a different light." $555 \mathrm{Re}-$ ligious sectarianism will not go away. Universal Unitarianism, even if desirable, is not going to come about. The Madisonian contribution, familiar to us from The Federalist Nos. Io and $5 \mathrm{I}$, is to understand factions, including religious factions, as a source of peace and stability. If there are enough factions, they will check and balance one another and frustrate attempts to monopolize or oppress, no matter how intolerant or fanatical any particular sect may be.

This point of view is consistent with an aggressive interpretation of the free exercise clause, which protects the interests of religious minorities in conflict with the wider society and thereby encourages the proliferation of religious factions. To increase the number of religious sects and the vigor of the small ones will not, as Locke

553 See supra text accompanying note $2 \mathrm{II}$.

554 On the difference between American styles of thinking and the ideas of the European

Enlightenment in other contexts, see D. BoorstiN, cited above in note 155 , at 149-52.

555 Letter from James Madison to Thomas Jefferson (Oct. 24, I787), reprinted in 5 THE Writings of JAMES MADISON, supra note IO9, at I\%, 29. 
appeared to believe, exacerbate the problem of religious turmoil. More likely, it will make religious oppression all the more impossible and therefore all the more unprofitable to attempt. Rather than try to foster an ecumenical spirit, the state allows each sect to promote its own cause with zeal. The Madisonian perspective points toward pluralism, rather than assimilation, ecumenism, or secularism, as the organizing principle of church-state relations. Under this view, the Supreme Court errs if it attempts to calm or suppress religious fervor by confining it to the margins of public life. It should welcome religious participation in all its diversity and dissension. The Court should not ask, "Will this advance religion?," but rather, "Will this advance religious pluralism?" The Court should not ask, "Will this be religiously divisive?," but rather, "Will this tend to suppress expression of religious differences?" Most of all, the Court should extend its protection to religious groups that, because of their inability to win accommodation in the political process, are in danger of forced assimilation into our secularized Protestant culture. The happy result of the Madisonian solution is to achieve both the unrestrained practice of religion in accordance with conscience (the desire of the religious "sects") and the control of religious warfare and oppression (the goal of the Enlightenment).

So understood, the free exercise clause also makes an important statement about the limited nature of governmental authority. While the government is powerless and incompetent to determine what particular conception of the divine is authoritative, the free exercise clause stands as a recognition that such divine authority may exist and, if it exists, has a rightful claim on the allegiance of believers who happen to be American citizens. The actual occasions for free exercise exemptions may be rare now, as in our early history; but the importance of the principle outstrips its practical consequences. If government admits that God (whomever that may be) is sovereign, then it also admits that its claims on the loyalty and obedience of the citizens is partial and instrumental. Even the mighty democratic will of the people is, in principle, subordinate to the commands of God, as heard and understood in the individual conscience. In such a nation, with such a commitment, totalitarian tyranny is a philosophical impossibility.

Dissenting in West Virginia Board of Education v. Barnette, 556 Justice Felix Frankfurter wrote:

The constitutional protection of religious freedom terminated disabilities, it did not create new privileges. It gave religious equality, not civil immunity. Its essence is freedom from conformity to religious dogma, not freedom from conformity to law because of religious 
dogma. ... Otherwise each individual could set up. his own censor against obedience to laws conscientiously deemed for the public good by those whose business it is to make laws. ${ }^{557}$

So saying, Justice Frankfurter overlooked the unique American contribution to church-state relations and embraced instead the Enlightenment ideal of Locke and Jefferson. Locke and Jefferson may well have been animated, in Justice Frankfurter's words, by the "freedom from conformity to religious dogma." But that is not what the Baptists, Quakers, Lutherans, and Presbyterians who provided the political muscle for religious freedom in America had in mind. To them, the freedom to follow religious dogma was one of this nation's foremost blessings, and the willingness of the nation to respect the claims of a higher authority than "those whose business it is to make laws" was one of the surest signs of its liberality.

557 Id. at 653 (Frankfurter, J., dissenting). 